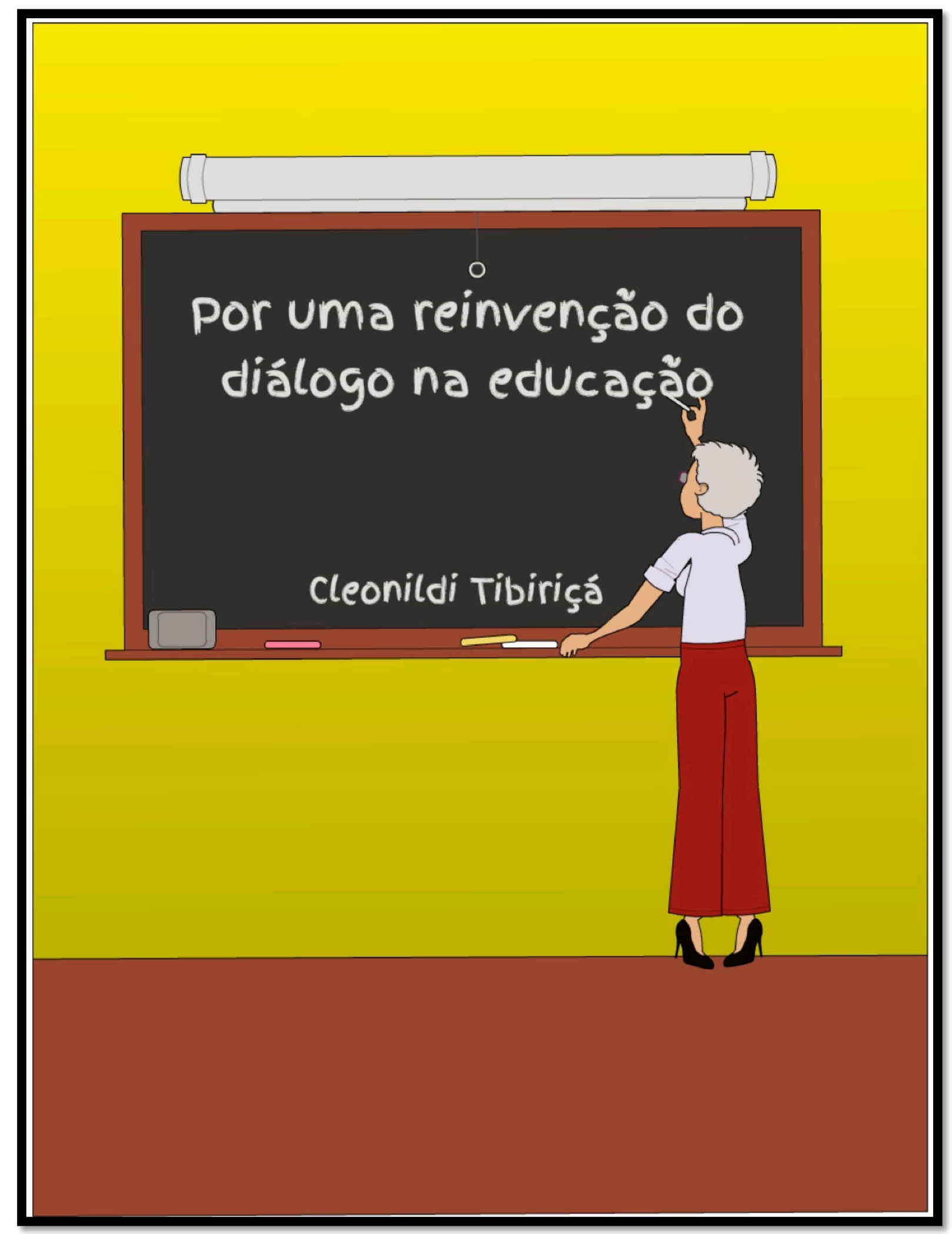

São Paulo 2015 


\author{
UNIVERSIDADE DE SÃO PAULO \\ ESCOLA DE COMUNICAÇÕES E ARTES \\ PROGRAMA DE PÓS-GRADUAÇÃO EM CIÊNCIAS DA COMUNICAÇÃO
}

\title{
CLEONILDI TIBIRIÇÁ
}

\section{POR UMA REINVENÇÃO DO DIÁLOGO NA EDUCAÇÃO}

Tese apresentada ao Programa de Pós-graduação em Ciências da Comunicação, na Área de Concentração III - Interfaces Sociais da Comunicação, da Linha de Pesquisa Comunicação e Educação, da Escola de Comunicações e Artes da Universidade de São Paulo (PPGCOM-ECAUSP), como exigência parcial para a obtenção do Título de Doutor em Ciência da Comunicação, sob a orientação da Prof ${ }^{a}$. Dr ${ }^{\text {a }}$. Lucilene Cury.

SÃO PAULO

2015 
Tese apresentada ao Programa de Pós-graduação em Ciências da Comunicação, na Área de Concentração III - Interfaces Sociais da Comunicação, da Linha de Pesquisa Comunicação e Educação, da Escola de Comunicações e Artes da Universidade de São Paulo (PPGCOM-ECAUSP), como exigência parcial para a obtenção do Título de Doutor em Ciência da Comunicação, sob a orientação da Profa. Dr ${ }^{a}$. Lucilene Cury.

SÃO PAULO

2015 
Autorizo:

[ ] divulgação do texto completo em bases de dados especializadas.

[ ] reprodução total ou parcial, por processos fotocopiadores, exclusivamente para fins acadêmicos e científicos.

Assinatura:

Data: 
A tese de doutorado Por uma reinvenção do diálogo na educação, realizada pela aluna Cleonildi Tibiriçá sob orientação da Profa ${ }^{a}{ }^{a}$. Lucilene Cury, foi , no dia ______ pela banca composta pelos professores doutores:

Prof. Dr. Instituição:

Julgamento: Assinatura:

Prof. Dr. Instituição:

Julgamento: Assinatura:

Prof. Dr. Instituição:

Julgamento: Assinatura:

Prof. Dr. Instituição:

Julgamento: Assinatura:

Prof. Dr. Instituição:

Julgamento: Assinatura: 


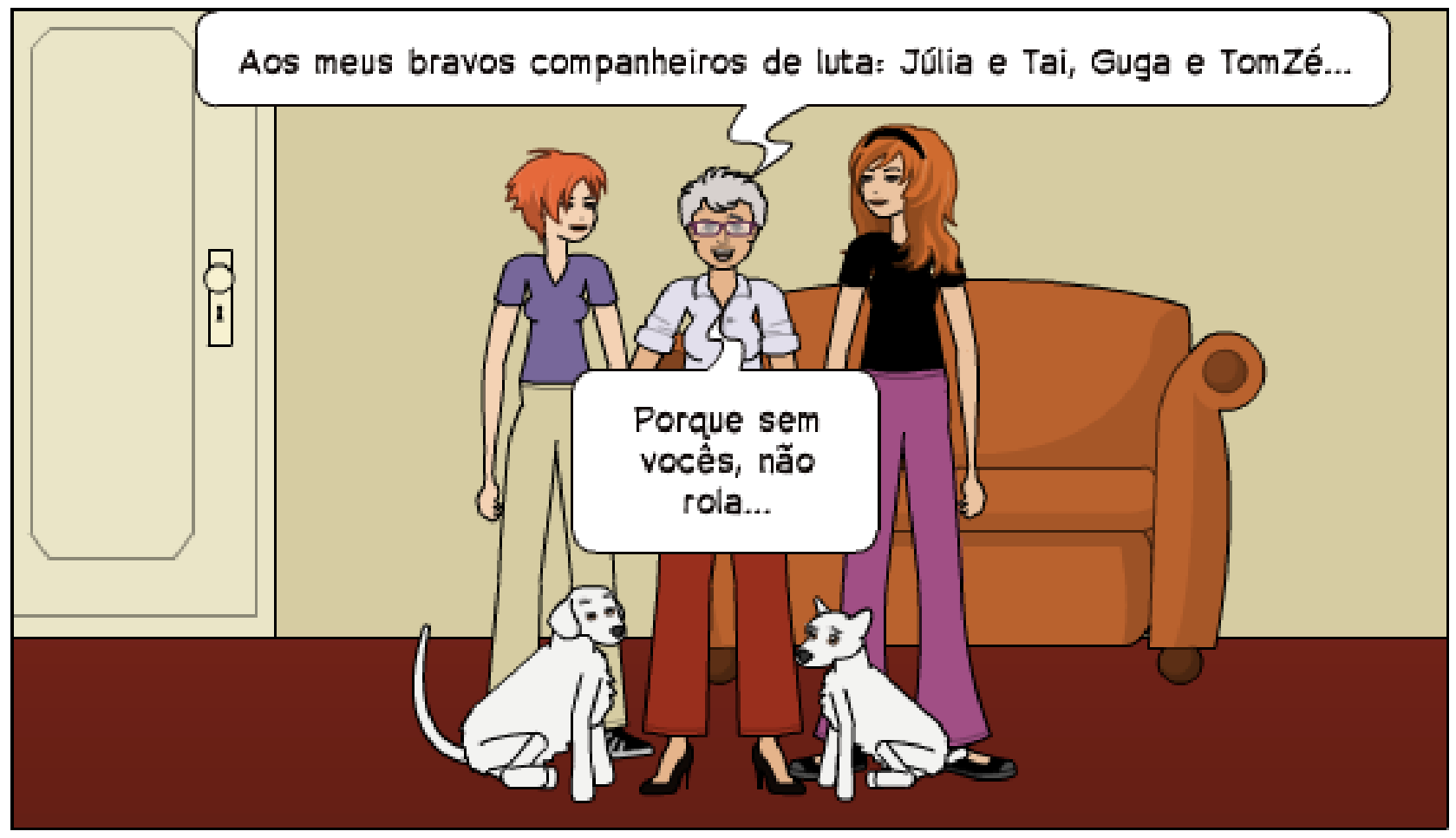




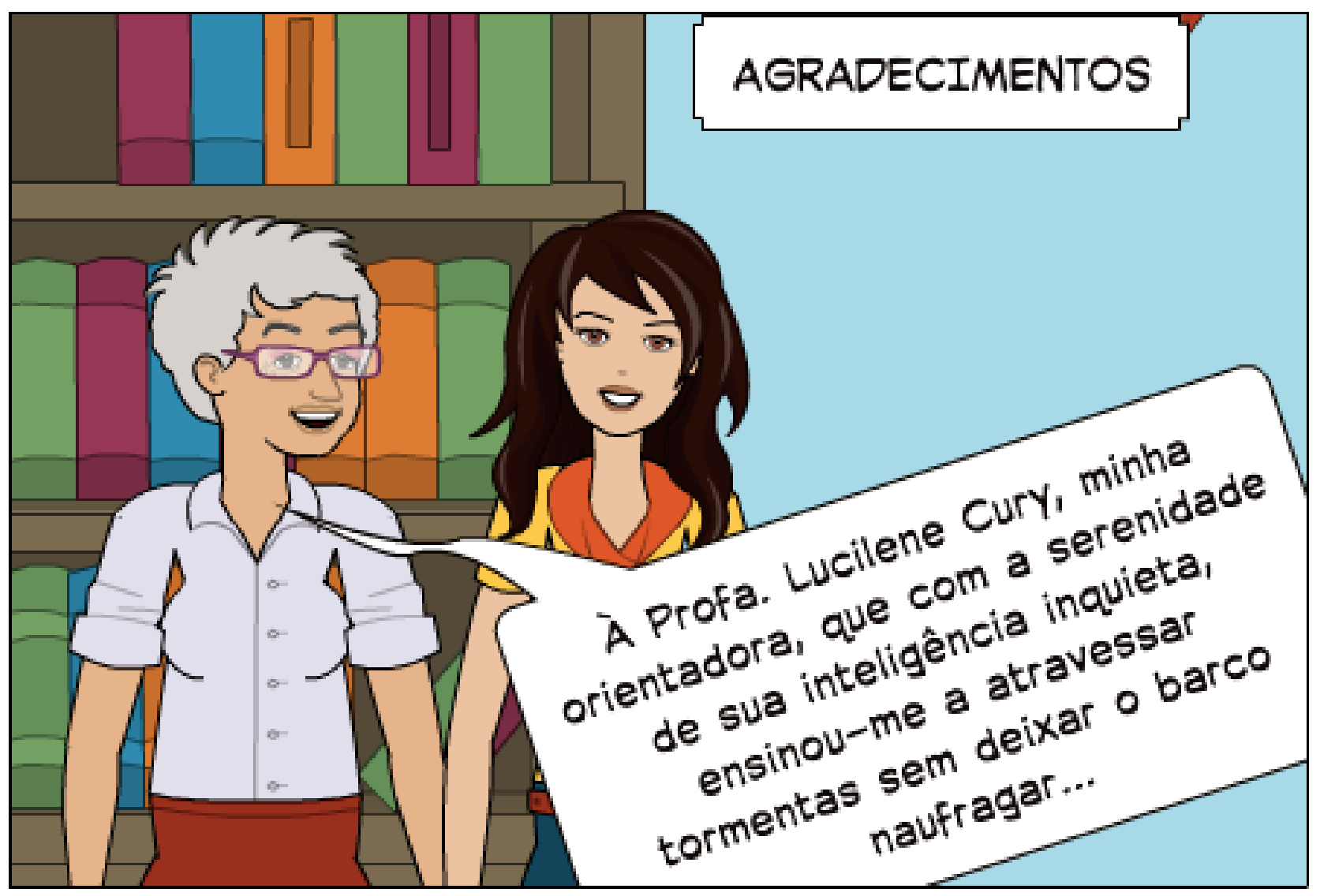




\section{RESUMO}

Este trabalho teve início numa investigação de resultados do ensino a distância como estratégia de ampliação do acesso ao ensino superior e de formação de professores para a educação básica. Durante o percurso, evidenciouse que não se poderia fazer a crítica dos resultados quantitativos favoráveis e dos resultados qualitativos desfavoráveis no contexto específico do ensino a distância mediado por tecnologias, porque esses resultados reproduziam o desempenho da educação brasileira como um todo, seja 'de perto', seja 'a distância', e se inscreviam num contexto muito mais complexo do que a falsa polêmica da presencialidade versus virtualidade. Identifica-se nas dualidades estruturais históricas do sistema educacional brasileiro, na assunção - por vezes assumida, por vezes sutil - de um projeto de educação alinhado às necessidades e caprichos do mercado - e na ausência de diálogo objetivo e subjetivo entre a Universidade e o ensino básico dimensões importantes do problema educacional do país. Propõe-se uma urgente reinvenção do diálogo sobre e na educação, e especificamente uma ação comunicativo-pedagógica na instância da educação tecnológica representada pelas FATECs - Faculdades de Tecnologia do Estado de São Paulo - a ser implementada pela Coordenação de Ensino Superior do Centro Paula Souza.

PALAVRAS-CHAVE: educação; educação tecnológica; comunicação; interação entre níveis de ensino; papel da universidade. 


\begin{abstract}
This paper began with an investigation of the results of distance education as an strategy of boardening the access to higher education and basic education formation for teachers. During this time, it became clear that the criticism of the quantitative positive results and of the negative ones couldn't be done, because these results mirrored the Brazilian education as a whole, from up close or far away, and they were inserted in a much more complex context than the false polemics of virtuality vs presence. It is identified in the historic structural dualities of the Brazilian educational system, in the assumption - usually subtile - of a educational Project aligned to the self centered necessities of the Market - and in the absence of objective dialogue about technological education and inside techonological education represented by the FATECs - Faculdade de Tecnologia do Estado de São Paulo - to be implemented by the coordination of higher education of Centro Paula Souza
\end{abstract}

KEY WORDS: education; technological education; communication; interaction between education levels; university role. 


\section{SUMÁRIO}

1 Preâmbulo $\quad 9$

2 Todos pela Educação. Só que não 17

2.1. Comunicação que é bom, nada 31

2.2. Igual, mas diferente 35

3 Breve histórico da educação brasileira e seu projeto excludente e elitista

4 Alguns números da educação superior brasileira segundo os números do censo de 2013: O difícil combate à educação elitista e privatista

5 Reinventando o dialogo

5.1. Aproximação entre ensino superior e ensino básico: ênfase no ensino por pesquisa/projeto

5.2. Aproximação entre ensino superior e ensino básico: ênfase na formação continuada de professores

5.3. Proposta de ação comunicativo-pedagógica para a construção de alternativa e intervenção transformadoras da educação tecnológica

6 Considerações Finais

6.1. Um mundo coberto de papers... mas, ... 'vocês não estão entendo nada!78

6.2. O direito democrático aos caminhos da pesquisa e à participação no bolo do conhecimento acumulado

7 Referências

\section{Bibliografia}

Consultada

o! Indicador não definido.

9 Anexos 



\section{Preâmbulo}


"Deixa, deixa, deixa

Eu dizer o que penso desta vida

Preciso demais desabafar"

(Ivan Lins)

Este trabalho não foi desenvolvido por uma pesquisadora especialista em educação, mas sim, por uma professora, a partir de um envolvimento já bastante longo com as dores e as delícias da práxis pedagógica.

É do lugar dessa militância, que por vezes resulta numa crítica um tanto ácida, que se constrói este trabalho, não como uma tese que contém um desabafo, mas como um desabafo que contém uma tese.

Recorrentemente se levanta um lamento pela situação crítica da educação brasileira. Publicam-se artigos, editoriais e comentários nos jornais de grande circulação, matérias de pauta nos telejornais diários e nos programas de entretenimento semanais, e assim se instala a comoção nacional...

A última grande emoção resultou da publicação dos resultados do ENEM 2014: 500 mil inscritos zeraram a redação.

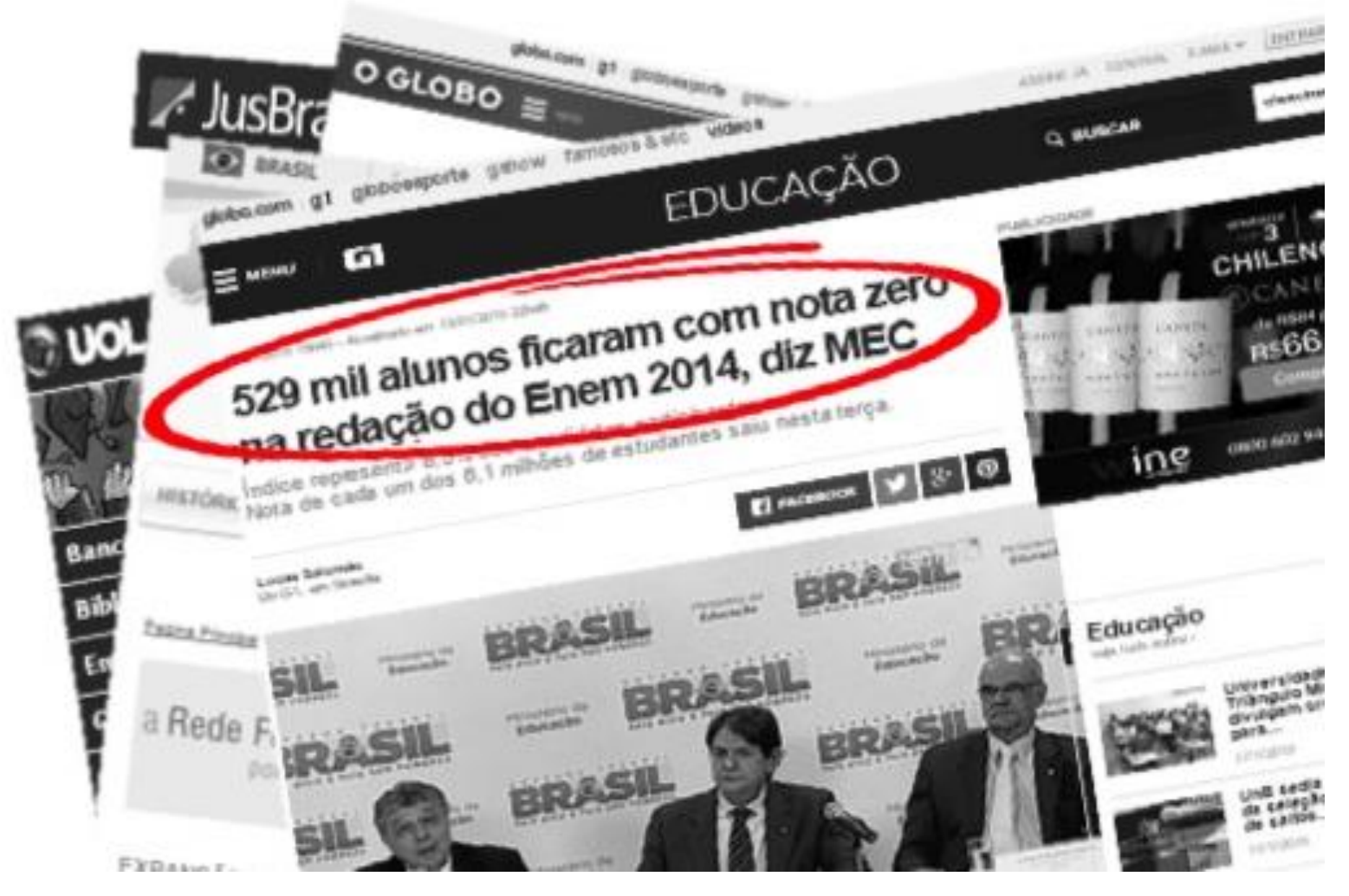




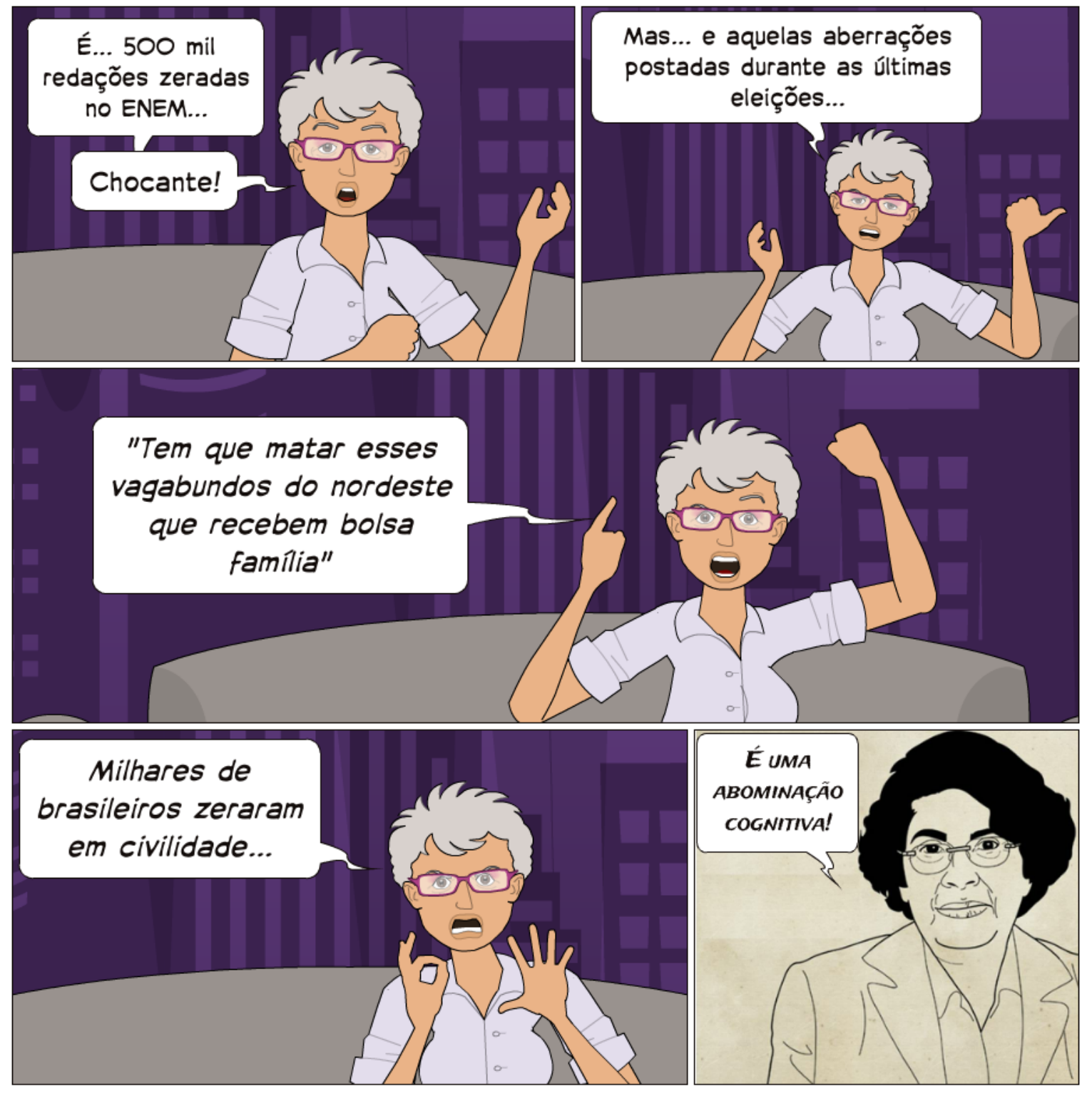


"Quem é você que não sabe o que diz?"

(Noel Rosa)

Quem acompanhou com um mínimo de lucidez as últimas eleições no Brasil e a batalha que se travou nas redes sociais durante todo o segundo turno e imediatamente após a vitória da candidata Dilma Roussef, não pôde deixar de sentir apreensão e repugnância diante dos milhares de brasileiros que zeraram em civilidade no decorrer do processo.

Mas, as declarações de ódio aos nordestinos, por exemplo, que alimentaram editoriais, blogs, posts no twitter e no facebook, não causaram nenhuma comoção quanto ao nível de formação humana promovido pela educação brasileira em todos os níveis.

Se considerarmos a performance cognitiva de parte significativa da população formalmente instruída durante esses eventos, o resultado apontado pelo ENEM, exame para o qual se inscreveram aproximadamente 6 milhões de brasileiros, no que diz respeito ao fato de APENAS 500 mil inscritos terem zerado numa redação que demandava uma reflexão sobre o controle da publicidade infantil merece, sim, uma comemoração, não um lamento.

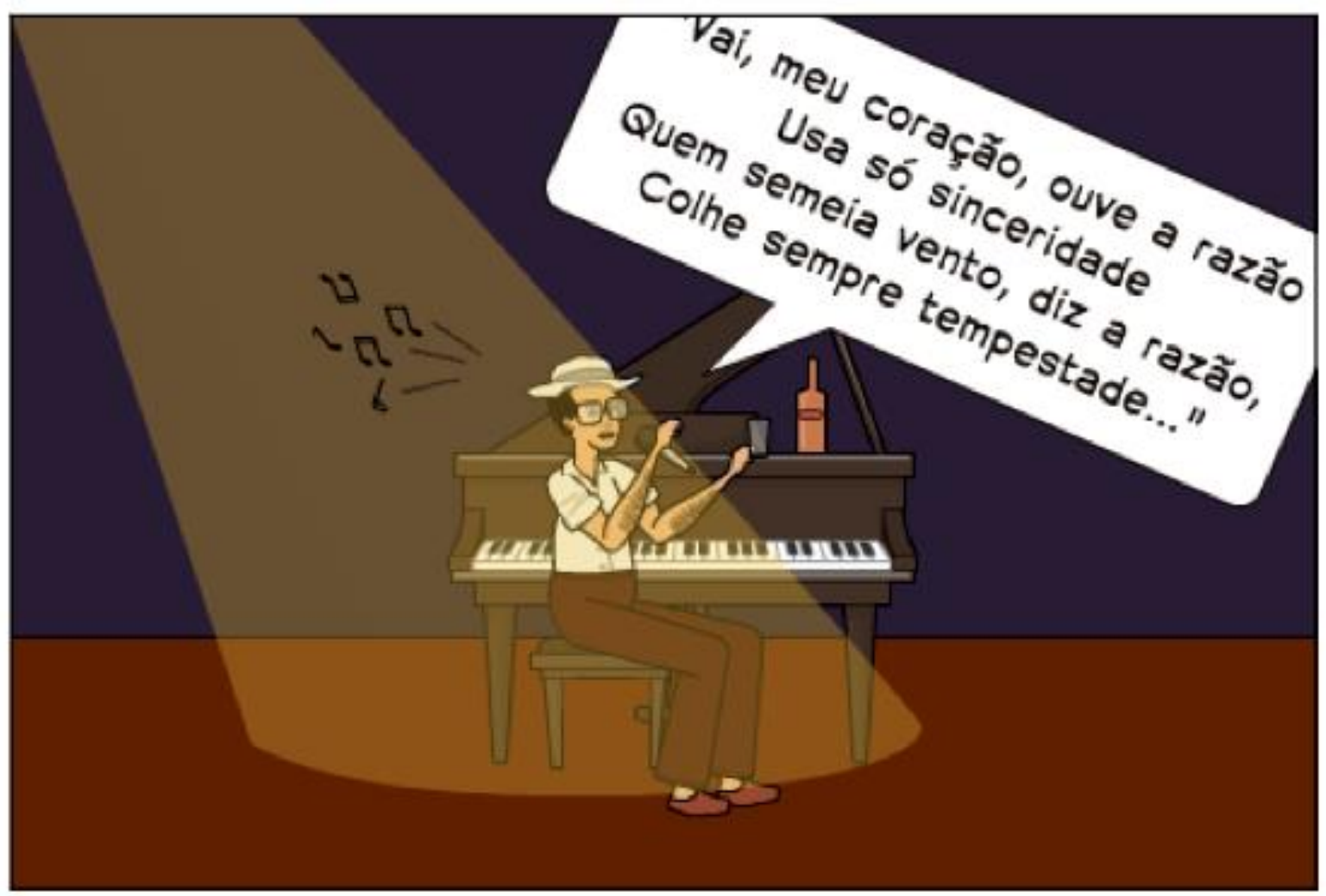




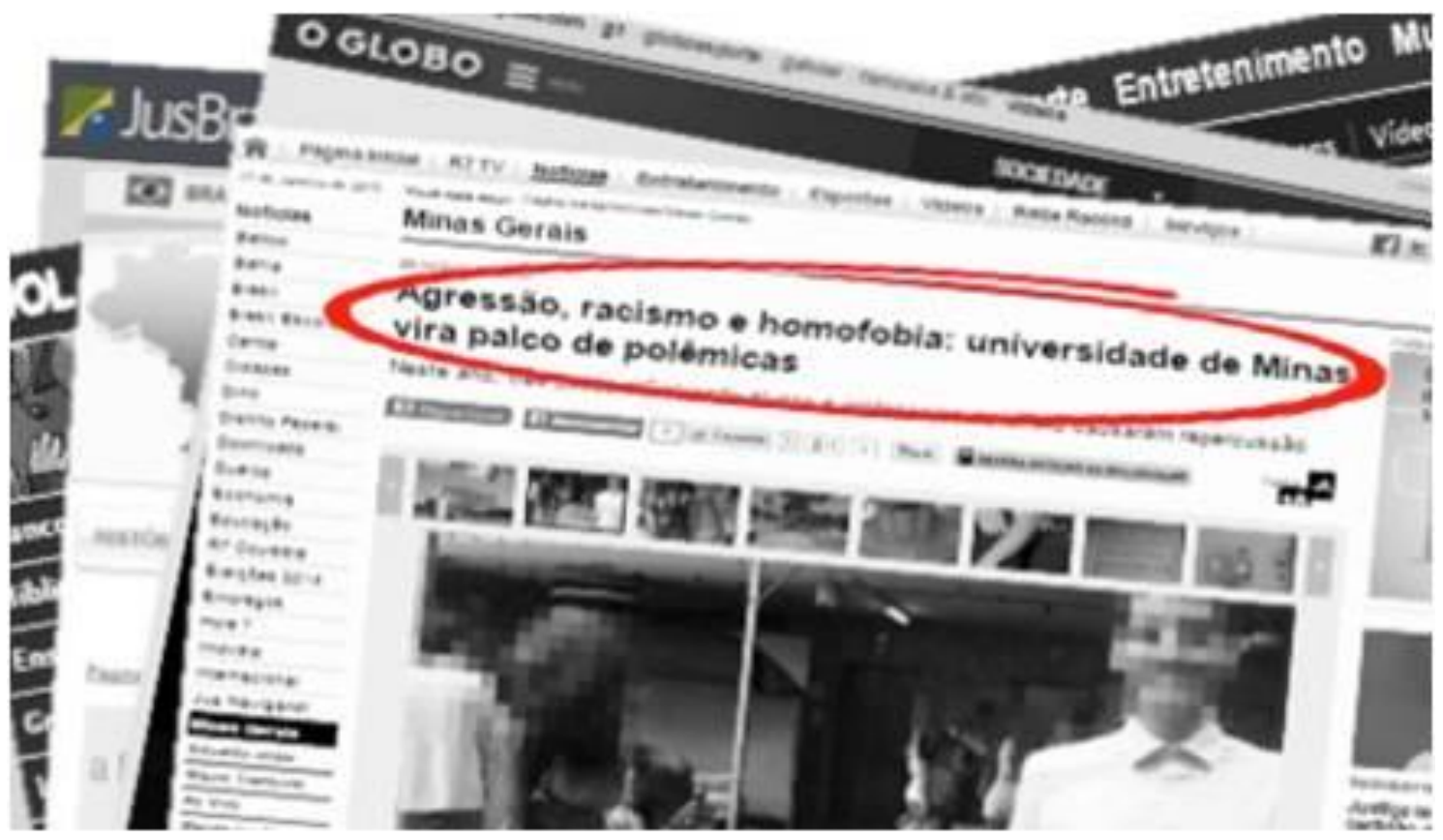

A perversão cobra um preço. Quem silencia e acata a perversão, quem adere a ela, tem que pagar o preço e assumir a sua responsabilidade pelo resultado das ações perversas. Ninguém está isento de responsabilidade no ocaso de inteligência que se verifica em nossa sociedade, principalmente a Universidade.

A perversão instituída pelos parâmetros neoliberais aplicados à formulação de políticas e práticas educacionais, responsável pela 'abominação cognitiva'1 que

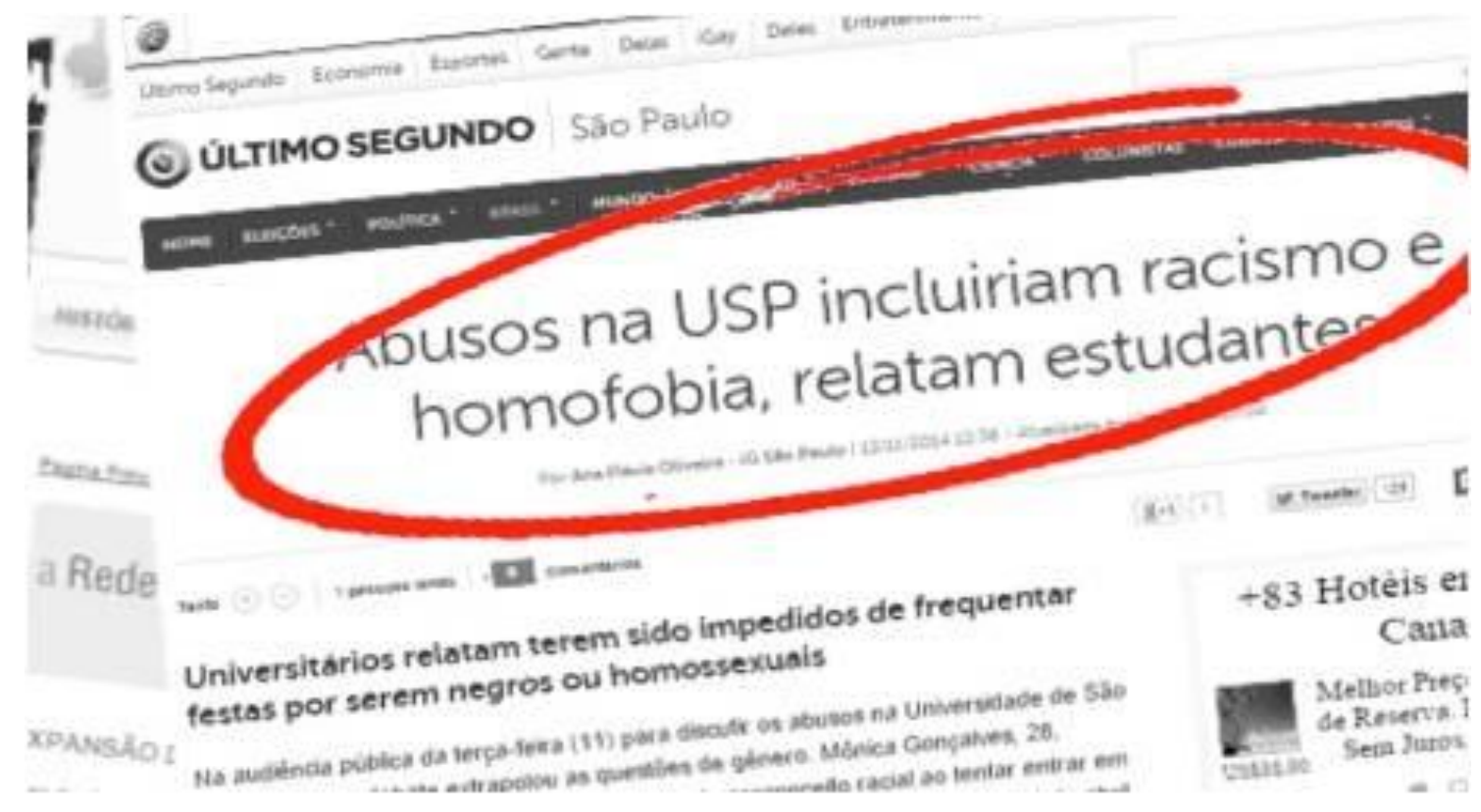

${ }^{1}$ A expressão é da Profa Marilena Chaui 
caracteriza o debate sobre as grandes questões contemporâneas entre a classe média urbana brasileira não é um processo de fácil reversão.

A pedagogia neoliberal, entendendo-se como neoliberalismo o conjunto de ideias políticas e econômicas que defende a não participação do estado na economia, se instaura e se expande em duas dimensões bem evidentes: por um lado, no privatismo concreto da expansão do negócio da educação; por outro, no privatismo ideológico que assola os corações e mentes da cultura educacional, pública e privada, e se traduz na ênfase de uma formação instrumental e adesista aos valores propagados pelo mundo-mercado.

A reforma universitária moldada no paradigma neoliberal já formou algumas

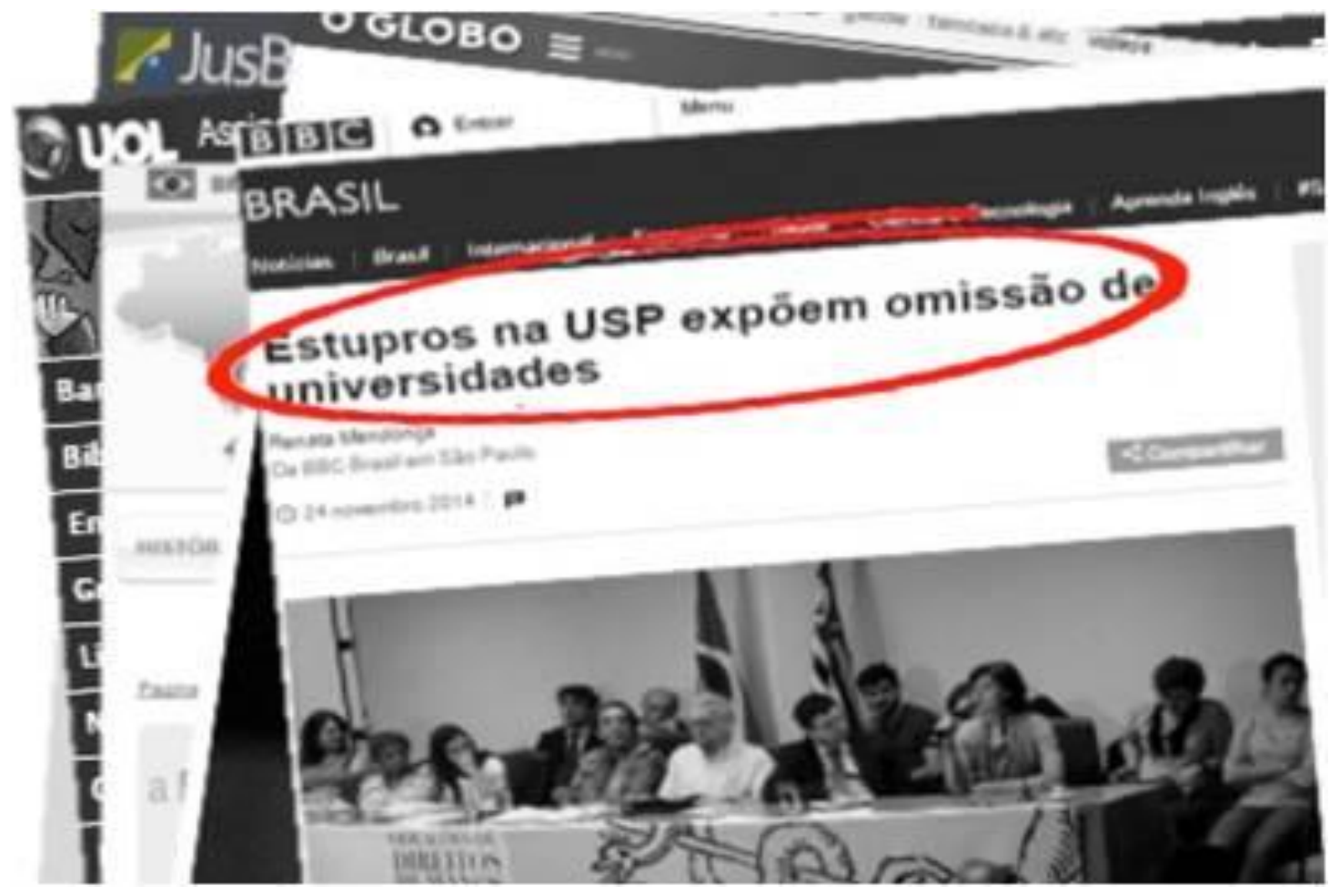

gerações bastante competentes para reproduzir o modelo pelo qual foram formadas. O ensino e a pesquisa são balizados por critérios quantitativos de produtividade, que reforçam o individualismo, a competitividade, o isolamento, características essenciais ao perfil daqueles que conseguirão a prosperidade e 0 sucesso na vida profissional, acadêmica ou não.

Como professora do ensino superior tecnológico há oito anos, venho acompanhando o acelerado processo de expansão quantitativa de instituições, cursos e vagas e a inexpressividade dessa expansão em termos de transformação qualitativa do diálogo que a educação tecnológica (não) estabelece com sua própria 
história, com o país, com a sociedade, com as tecnologias, com o mundo do trabalho e, portanto, com seus estudantes.

Nosso interesse é contribuir para a discussão sobre a educação brasileira em todos os níveis de ensino e para sua efetiva transformação rumo a uma

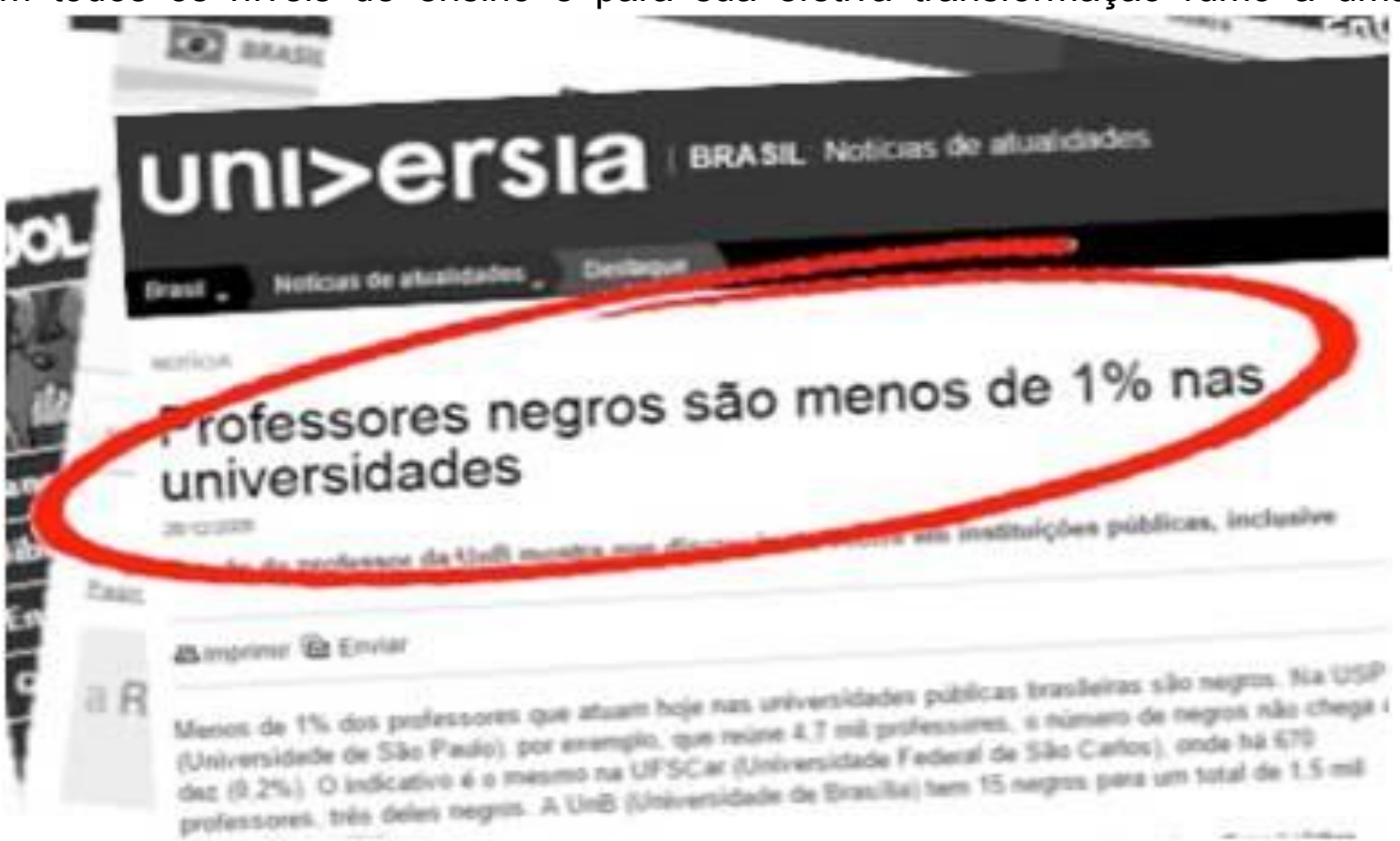

educação emancipadora e democrática, não porque o noticiário a-histórico sobre a crise nos tenha comovido, não porque o discurso de uma crítica acadêmica especializada e míope nos tenha cooptado, mas porque estamos há muito tempo na estrada e temos presenciado a implementação de mudanças que nada mudam em termos de desenvolvimento cognitivo, ético e humano dos estudantes, e que

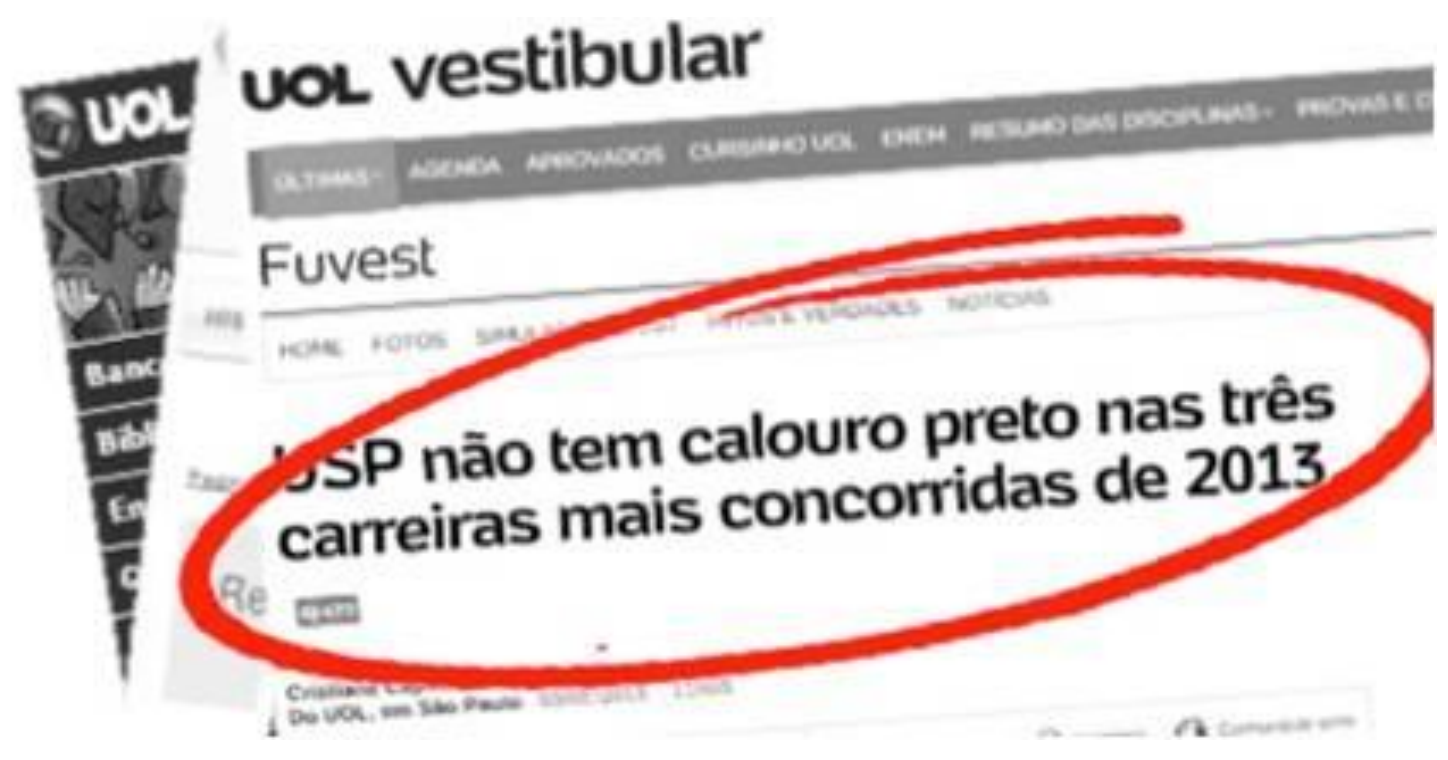


nada podem, mesmo quando bem intencionadas, contra a incompetência e a aridez do ambiente de individualismo vaidoso e produtivista de nossas instituições. 
2 Todos pela Educação. Só que não 
"A educação é comunicação, é diálogo, na medida em que não é a transferência de saber, mas um encontro de sujeitos interlocutores que buscam a significação dos significados." (FREIRE, 1985, como não podia deixar de ser...)

O período de redemocratização do país testemunhou intensa discussão e formulação de políticas educacionais com vistas a equacionar o problema da defasagem entre desenvolvimento econômico brasileiro e seu sistema de educação que, como nos demonstra Otaíza de Oliveira Romanelli ${ }^{2}$, é característica constitutiva da história da educação brasileira, desde os tempos coloniais.

Os diagnósticos mais recorrentes são os que enfatizam a "aprovação

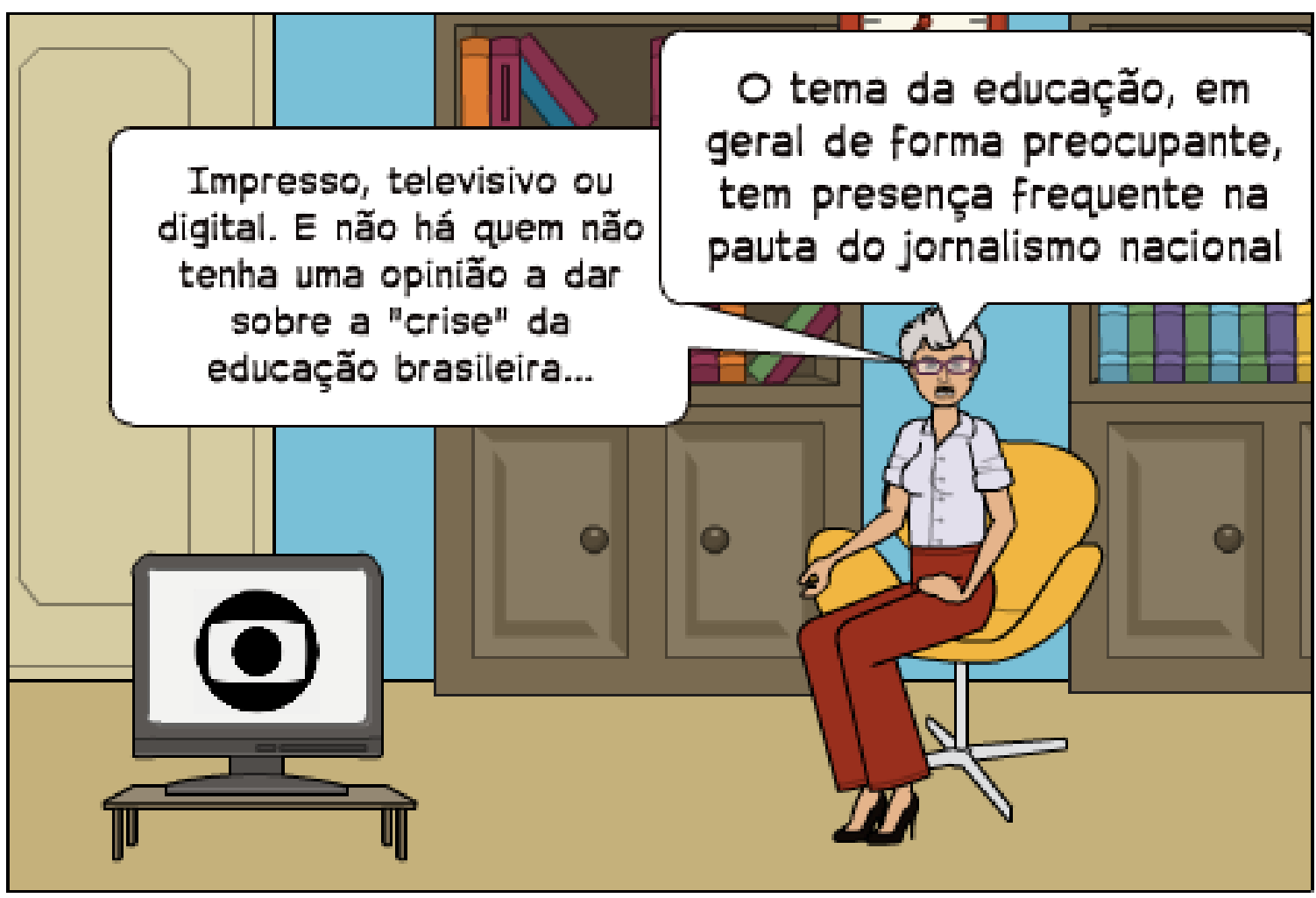

automática", a perda de autoridade do professor, os limites frouxos impostos pela família e a influência das tecnologias e das redes sociais que ocupam quase que integralmente o tempo e o interesse dos estudantes.

2 ROMANELLI, Otaíza de Oliveira. História da Educação no Brasil. 8. Ed. Petrópolis: Editora Vozes, 1986. 


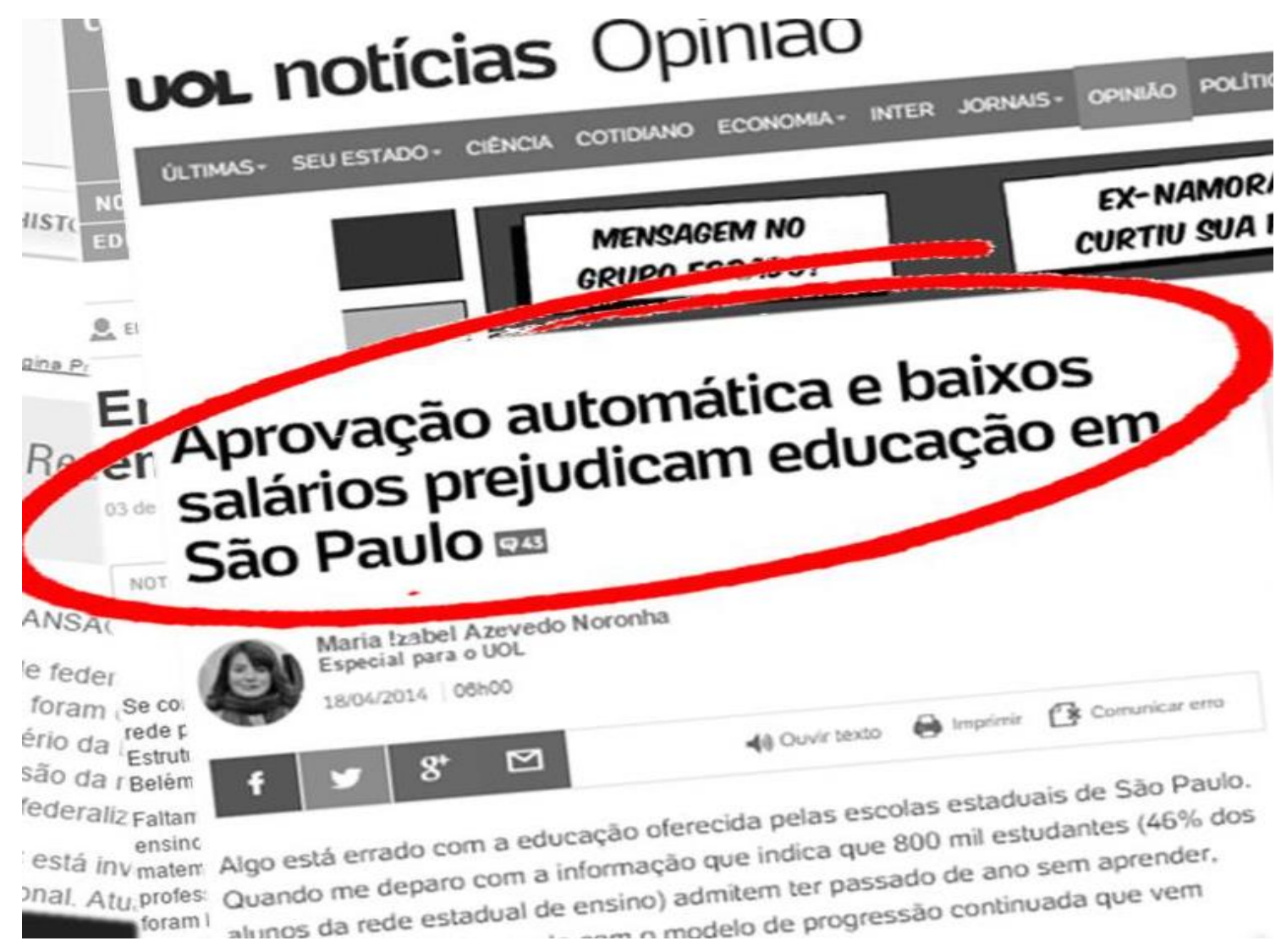

() ULIW'-

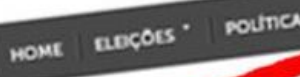

Docentes acham que ECA é permissivo e facilita a indisciplina, mostra estudo

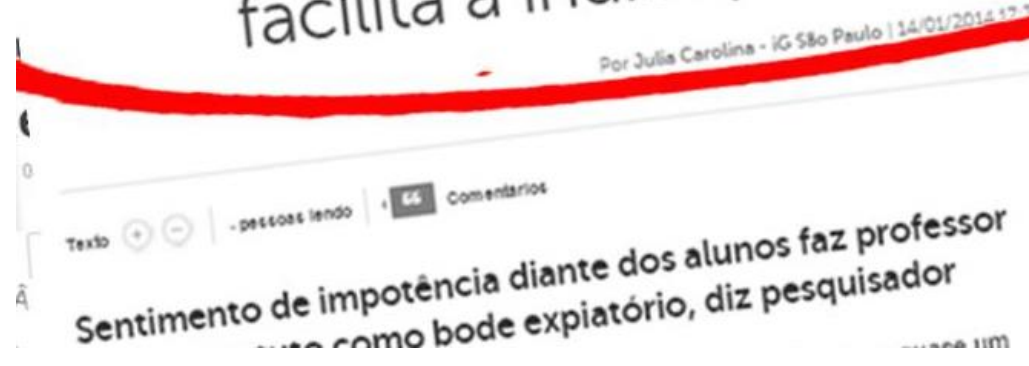




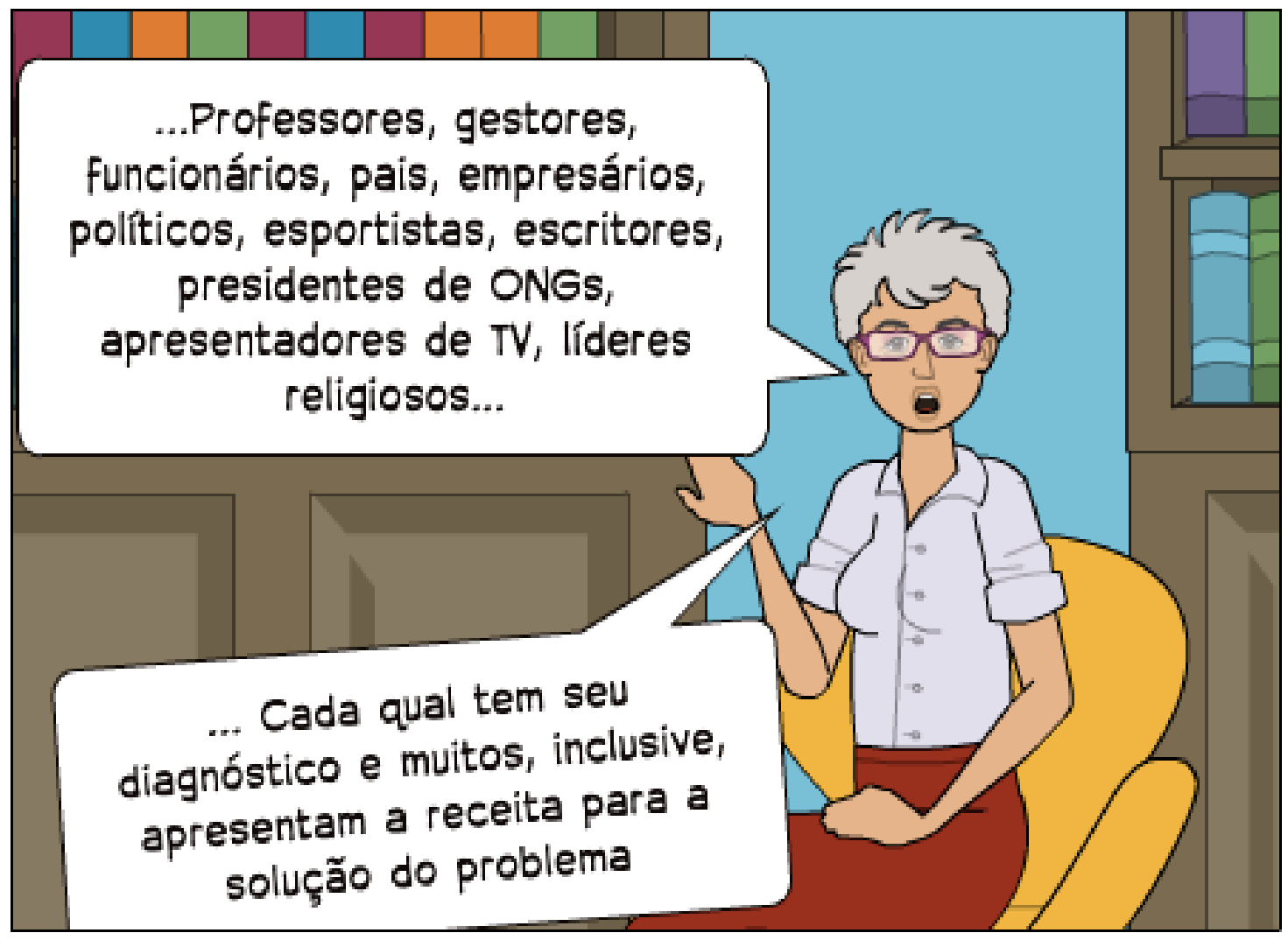

Inegável a precariedade de nossa educação e sua falta de sintonia com as transformações da vida social e do mundo do trabalho, mas é inegável - e qualquer investigação superficial já o revela - a impropriedade ou ingenuidade de boa parte da crítica veiculada pelos "especialistas" midiáticos e seus seguidores. Se, por um lado, há os que simplesmente não sabem do que estão falando, por outro, há os que sabem muito bem do que está na origem de nossa miséria educacional, mas "ressignificam" (para usar um termo bem ao gosto dos ressignificadores de plantão) os fatos para que eles se acomodem aos seus interesses de grupo ou de classe. Nesse último caso, estão muitos especialistas da área que desde o final do século passado vem apostando no fim da educação igualitária, pública e gratuita, por exemplo.

Aplicam-se então todas as receitas prescritas pelo mercado de trabalho (e seus representantes na academia e na mídia), que, apesar de 'cliente' insatisfeito com o 'produto' que vimos fornecendo, coloca-se na posição proativa de 'não só reclamar' mas, sobretudo, 'contribuir para a solução do problema'. Coaching, técnicas de treinamento comportamental e motivação, políticas de premiação, bônus por resultados - vale tudo na tentativa (às vezes ingênua, às vezes 
oportunista) de sedimentar a cultura mercantil e instrumental das corporações no contexto escolar, de promover mudanças sem nada mudar, de alterar resultados numéricos e estatísticos sem alterar o modus operandi e, sobretudo, de produzir ações vazias em ritmo frenético que geram notícias, artigos, encontros, capacitações, contratação de consultorias e projetos - sem, é claro, 'ficar perdendo tempo' com estudo, reflexão e DIÁLOGO.

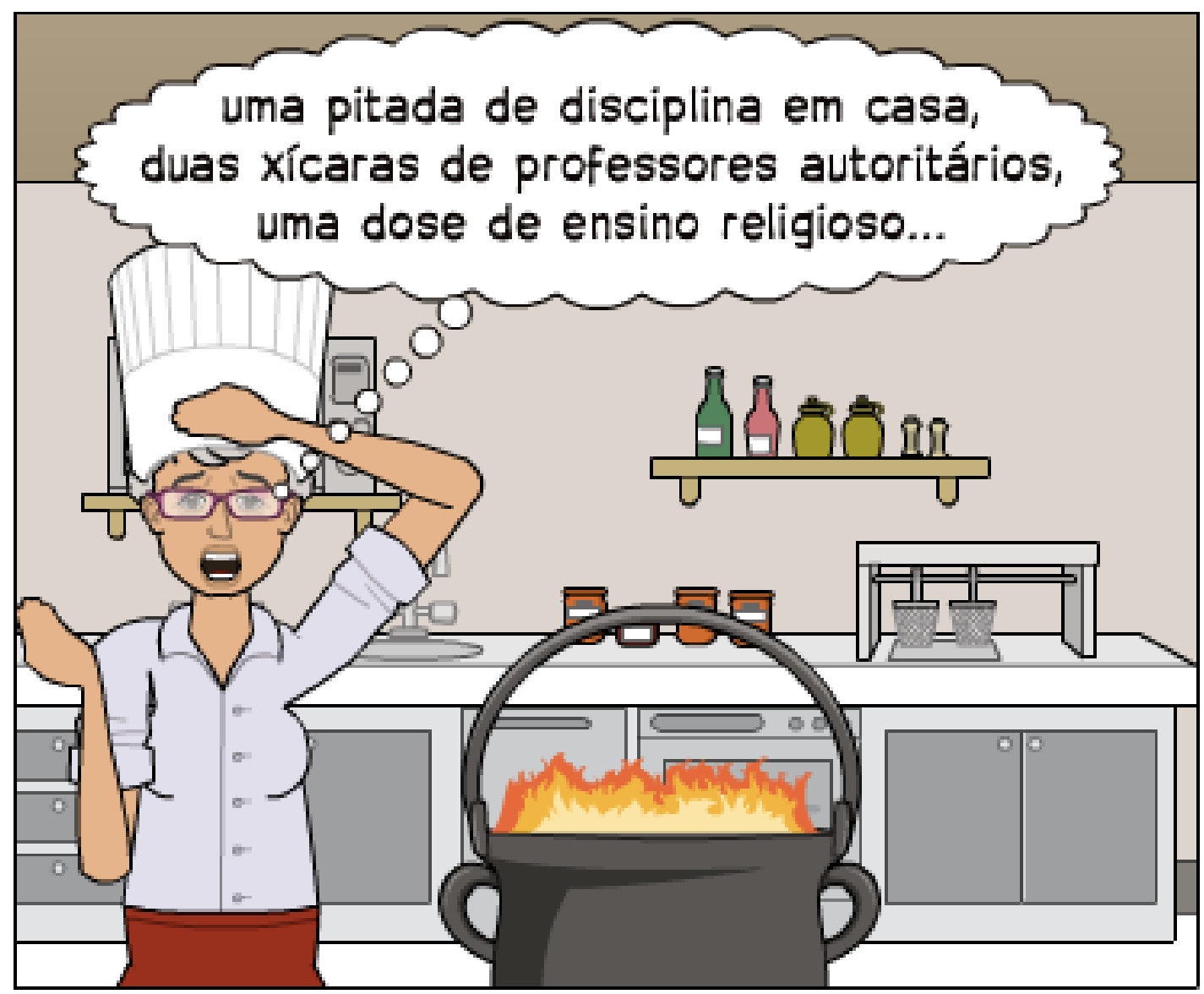

Como a 'solução para todos os seus problemas' nunca resolve todos os seus problemas - geralmente faz o contrario -, o fenômeno da evasão, em todas as suas dimensões - abandono, desistência, trancamento, assiduidade mínima -, a queda do número de inscritos nos vestibulares e a dificuldade para formação de turmas em grande número de cursos, têm preocupado os gestores e provocado inúmeras ações no sentido de tratar os sintomas, sem um profundo processo de reflexão sobre as causas, com o qual - assim pensam muitos gestores e docentes - 'não podemos perder tempo'. 


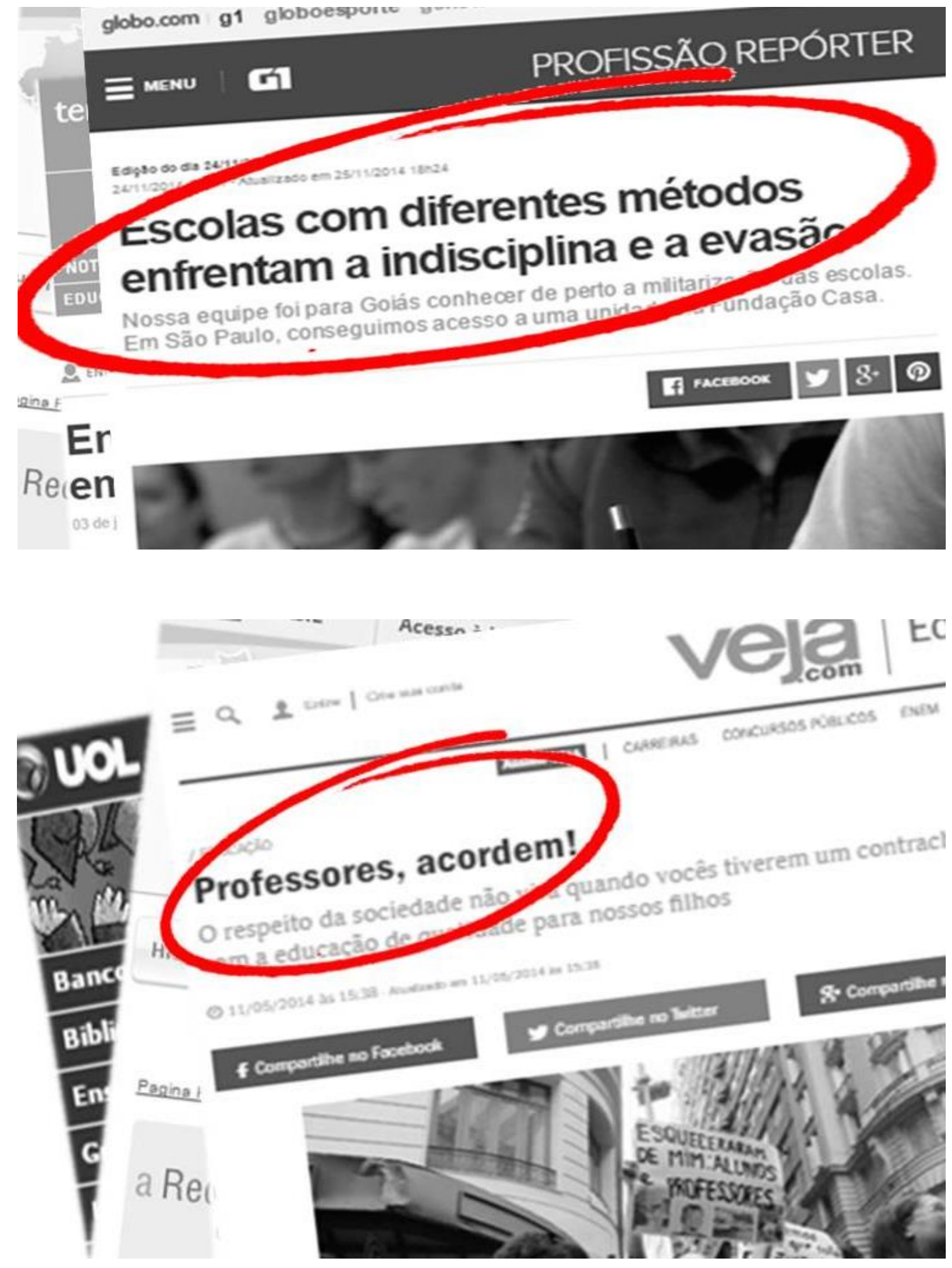




\section{/ tecnologia / vida virtual}

-Atualizado em 16/09/09 - 12h58

\section{Vício' em tecnologia atrapalha} aprendizado de adolescentes, diz estudo

Abreviação de mensagens de texto pode prejudicar grafia de n
web.

Como os professores devem lidar com poder e autoridade na sala de aula

- 2t de Setembro de 201 ?

E Como professor, voce deve comandar a sua sala de aula de maneira eficaz e produtiva. Confira algumas técnicas de gestão de alunos para lidar com poder

tel autoridade de forma positiva
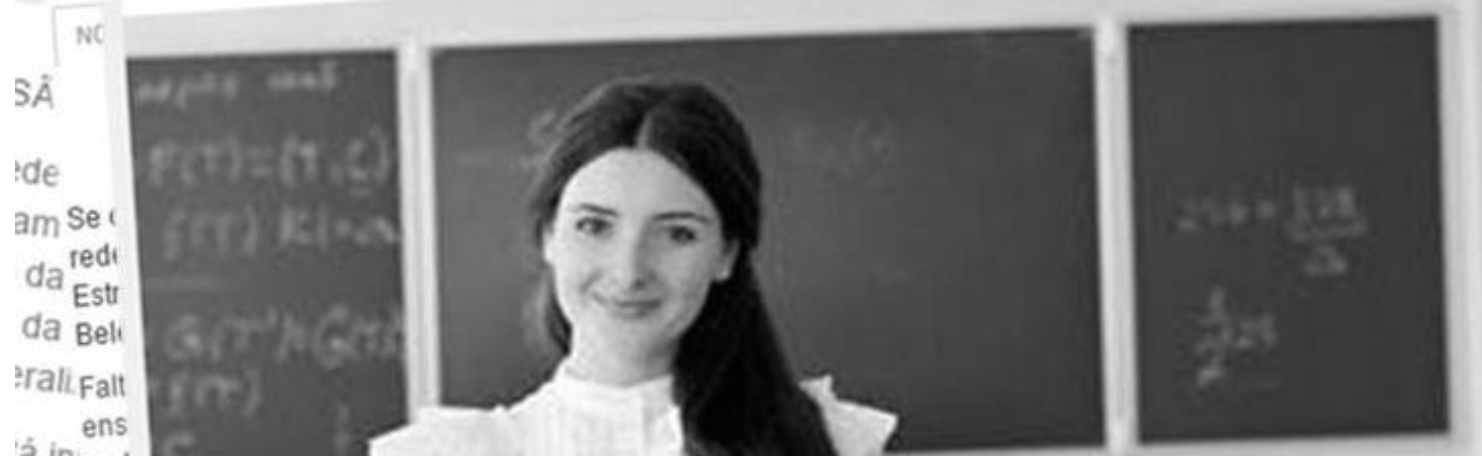
Os ambientes da educação são, cada vez mais, ambientes de medo e opressão. Os órgãos de controle e avaliação educacionais temem o relatório do Banco Mundial; os diretores das instituições temem o ministério, as secretarias, os órgãos de controle e avaliação, com seus famigerados rankings de pontuação, suas exigências impraticáveis de produtividade e eventuais políticas de bônus por resultados; os coordenadores de cursos, de departamentos ou de áreas temem os diretores, sua pressão por produção, por resultados, por desempenho, por tudo o que o que tenha força quantitativa e possa aparecer em índices numéricos e estatísticos; os professores temem os coordenadores, os processos de avaliação, a constante ameaça que representa a armadilha dos planos de evolução funcional e a concorrência das mídias; os alunos temem os professores, seu poder de vida e morte sobre eles, suas patéticos critérios de avaliação, sua descabida exigência quantitativa por trabalhos sem sentido além das provas que nada provam; as famílias temem o fracasso escolar dos filhos, maridos, mulheres ou pais, representado pelas notas baixas, pelas DPs, pelas reprovações, que acarretam custos financeiros e morais; e esse circuito de medo se retroalimenta em articulação constante com a mídia e o senso comum.

Nesse ambiente de medo, pressão e opressão que configura o ambiente educacional, não há espaço nem tempo para o diálogo e para a ação comunicativa. Os "comunicados" que circulam nos ambientes escolares, da pré-escola à universidade, não são construídos na interação de sujeitos que buscam significar o mundo; são "comunicados" estanques, cristalizados, repetíveis, transmissíveis, esvaziados de sua capacidade narrativa original, estéreis, incapazes de gerar conhecimento e transformação.

"A escola, neste caso, é utilizada muito mais para fazer comunicados do que para fazer comunicação e este papel é desempenhado tanto mais eficazmente, quanto mais o que se pretende com a ação escolar é formar o espírito ilustrado, não o espírito criador. Cedo ela se transforma numa instituição ritualista, onde o cumprimento de certas formalidades legais tem valor em si mesmo." (ROMANELLI, 1986) 

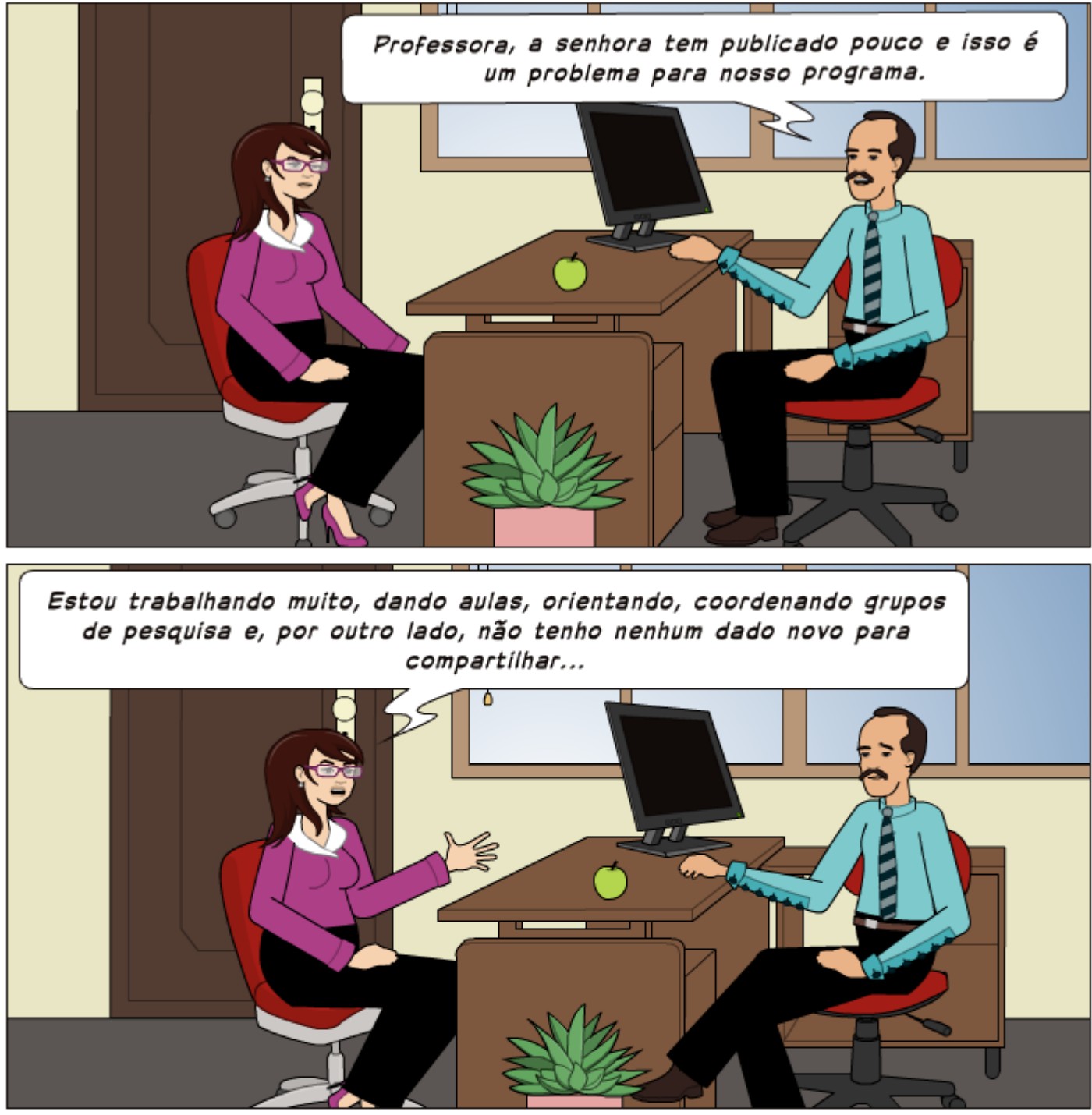

Professora, não interessa se a senhora tem ou não tem algo a dizer. A senhora tem que publicar e acabou. Dê uma reciclada em seus últimos artigos, mude os títulos e encaminhe para publicação. Afinal, a senhora está interessada ou não em evoluir na carreira?

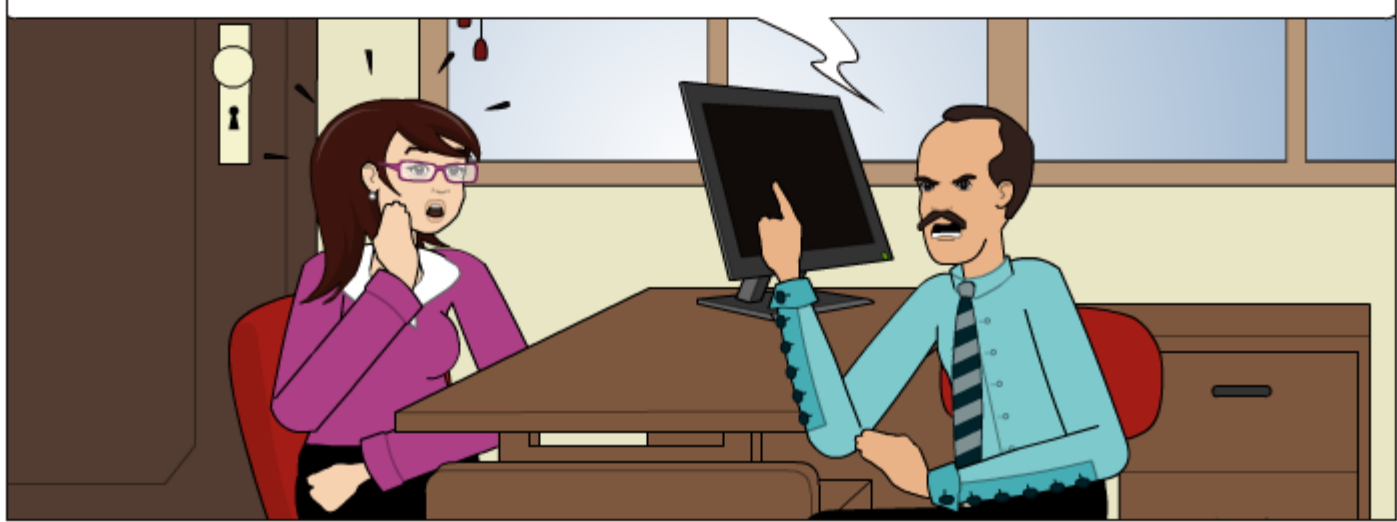


A gestão democrática das instituições escolares, preconizada na LDB e nos últimos PNEs como condição indispensável à melhoria da qualidade da educação, inviabiliza-se pelo recrudescimento das práticas autoritárias e burocráticas que dão conta de preservar a cultura do medo e garantir os tão esperados resultados quantitativos, medíocres, mas mensuráveis.

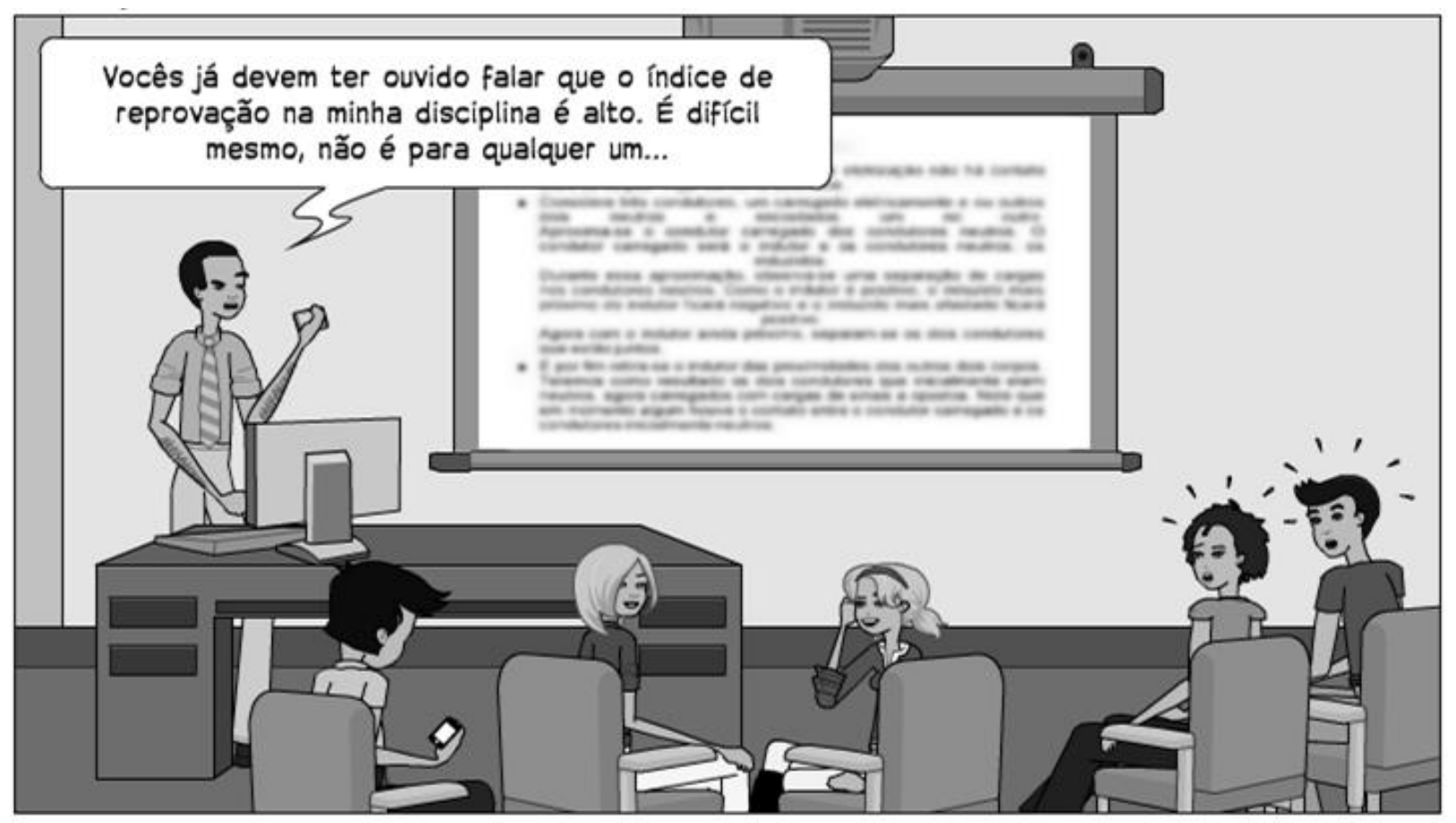

Como não podia deixar de ser, o perfil de profissional que se destaca nesse ambiente é o do burocrata tão medíocre quanto essa visão de educação, carreirista e tacanho, ele está sempre em sintonia com os instrumentos de controle e em absoluta dissintonia com as novas narrativas produzidas pelo mundo em transformação em que os estudantes estão imersos.

Por conta disso, as políticas educacionais que acertadamente buscam a expansão e a interiorização de vagas, a garantia de ações afirmativas para a inclusão de grupos historicamente alijados do acesso à educação, o estímulo à inserção das tecnologias nos processos pedagógicos, ainda que implementadas (muitas vezes a contragosto e de maneira distorcida), não produzem resultados significativos.

Nunca avaliamos tanto e fomos tão avaliados, nunca se investiu tanto em "capacitação" e oferta de cursos superiores para formação de professores, nunca 
se produziu tanta apresentação em PowerPoint para driblar a inércia e o tédio das salas de aula, nunca se falou tanto em sistemas integrados de gestão escolar, nem nunca se reformulou tanto e com tal frequência os projetos pedagógicos das instituições e os planos de ensino dos professores a título de inserir conteúdos e metodologias "modernizantes".

Em elucidativo artigo sobre os problemas da educação na Colômbia, Jesús

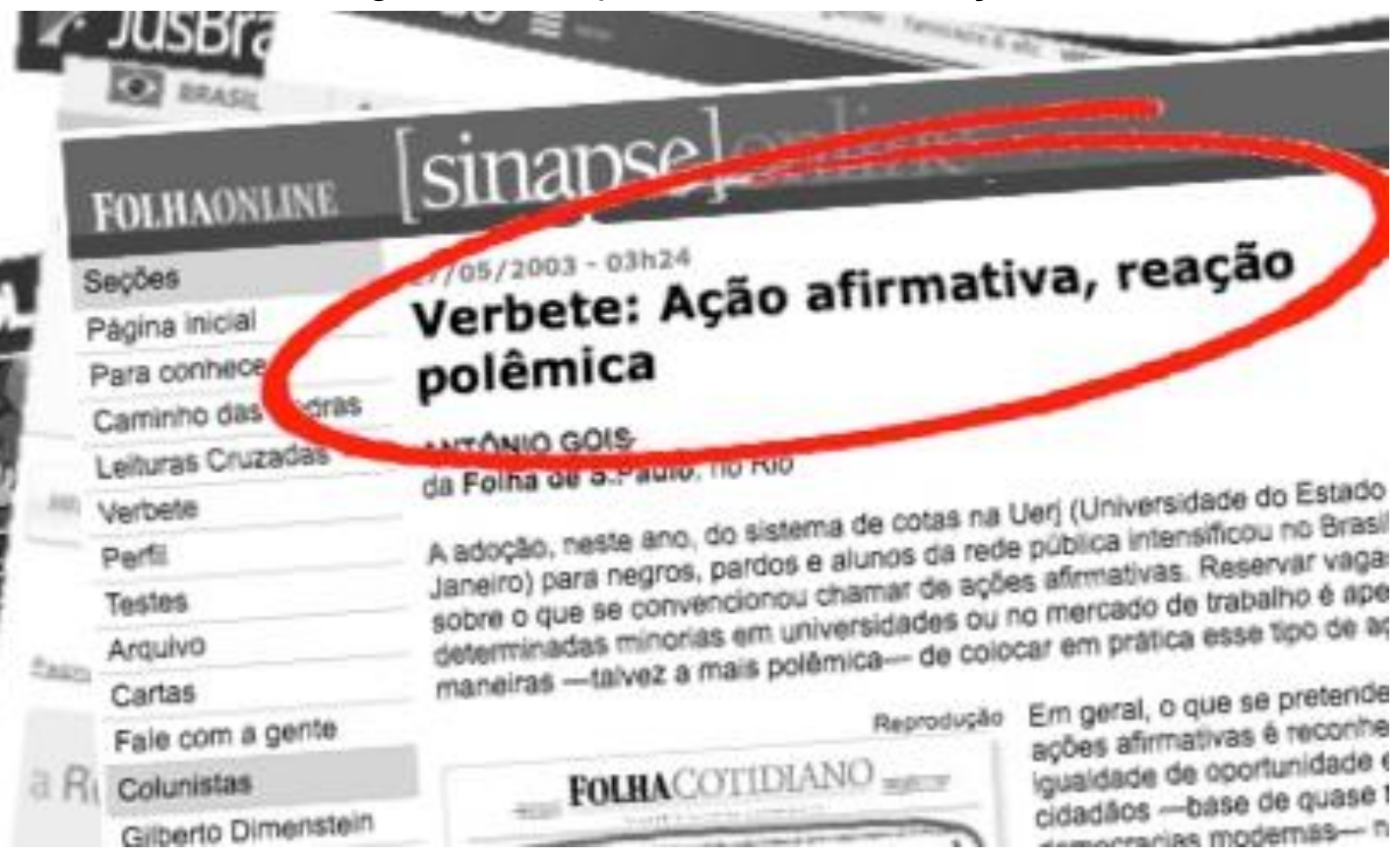

Martin Barbero, ao falar sobre a esquizofrenia que lá vigora, mantendo apartadas nas políticas e nas práticas a educação, a cultura e a comunicação, faz alerta que poderíamos sem qualquer receio aplicar ao Brasil:

"[...] vamos ter a coragem de colocar o problema fundamental: o que é que tem de mudar no sistema educacional - do Ministério às faculdades de educação, do ensino fundamental até a universidade - para que a escola se comunique com o país? Ou, de outro modo: o que tem de mudar no sistema educativo para que este possa incumbir-se de mostrar o que a Colômbia está vivendo e sofrendo, produzindo e criando; para que a escola possibilite às crianças e aos jovens uma compreensão do seu país que os capacite para ajudar a mudá-lo?' (BARBERO, 2000) (grifo nosso) 

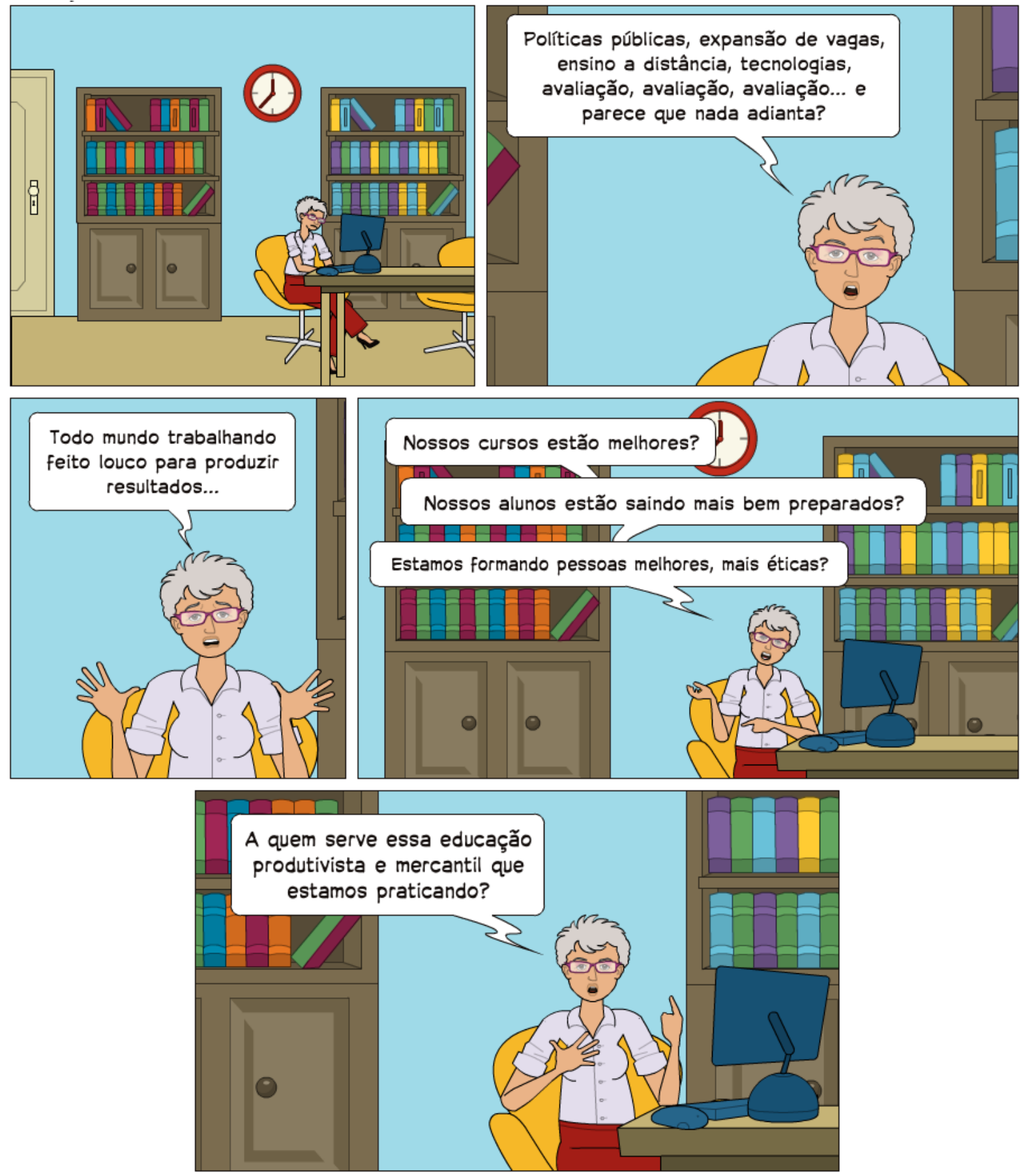
Se tivermos a coragem de identificar o problema fundamental de nosso sistema educacional, neutralizaremos a crítica de senso comum que circula tanto em meios leigos quanto em meios "especializados", e que insiste a-historicamente em resolver aquilo que se convencionou chamar de "crise da educação brasileira" pela introdução de métodos cada vez menos democráticos de gestão e modos de avaliação cada vez menos preocupados com processo e formação, preocupações que foram substituídas pela perversão da busca, a qualquer custo, por boas colocações nos índices medidores de eficiência das instituições e pela bonificação por resultados.

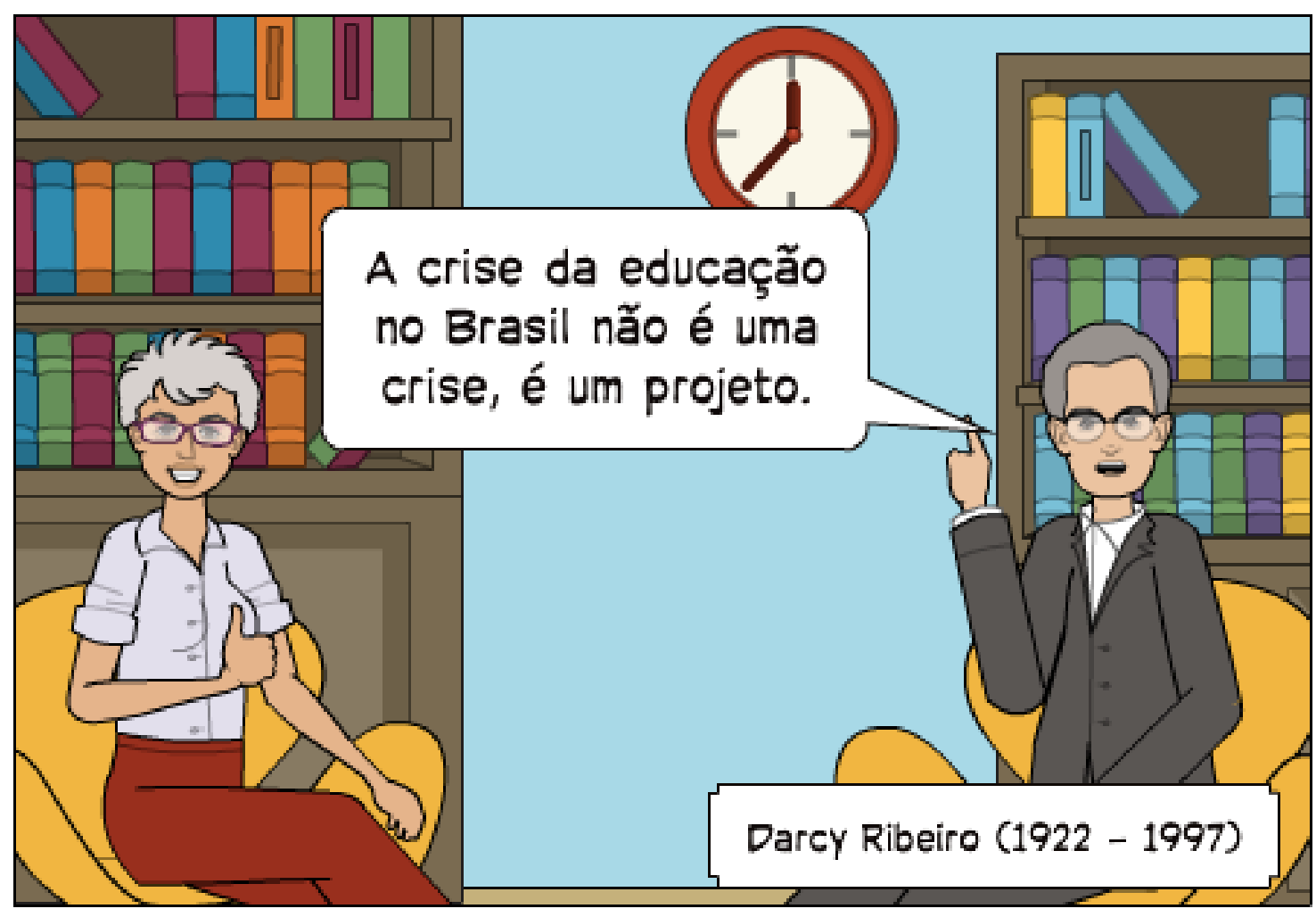

É novamente Barbero a nos alertar "que nada pode prejudicar mais a educação que nela introduzir modernizações tecnológicas sem antes mudar o modelo de comunicação que está por debaixo do sistema escolar." (BARBERO, 2000). E qual é o modelo de comunicação que está por debaixo do sistema escolar? É o modelo da transmissão, o modelo que pressupõe um polo irradiador e outro polo receptor de "comunicados" rígidos, previamente estabelecidos, e não o da interação comunicacional, que descentraliza o processo e posiciona os atores como sujeitos de construção de significados. 
"O modelo predominante é vertical, autoritário na relação professor-aluno e linearmente sequencial no aprendizado. Introduzir nesse modelo meios e tecnologias modernizantes é reforçar ainda mais os obstáculos que a escola tem para se inserir na complexa e desconcertante realidade de nossa sociedade. Ao colocar como ponto de partida as mudanças que são necessárias à escola para que ela possa interagir com o país e não simplesmente para a utilização dos meios de comunicação, estou enfrentando um mal-entendido que o sistema escolar não parece interessado em desfazer: a obstinada crença de que os problemas da escola podem ser solucionados sem que se transforme o seu modelo comunicativo-pedagógico, isto é, com uma simples ajuda de tipo tecnológico. E isso é um autoengano. Enquanto permanecer a verticalidade na relação docente e a sequencialidade no modelo pedagógico, não haverá tecnologia capaz de tirar a escola do autismo em que vive. Por isso, é indispensável partir dos problemas de comunicação antes de falar sobre os meios." (idem)
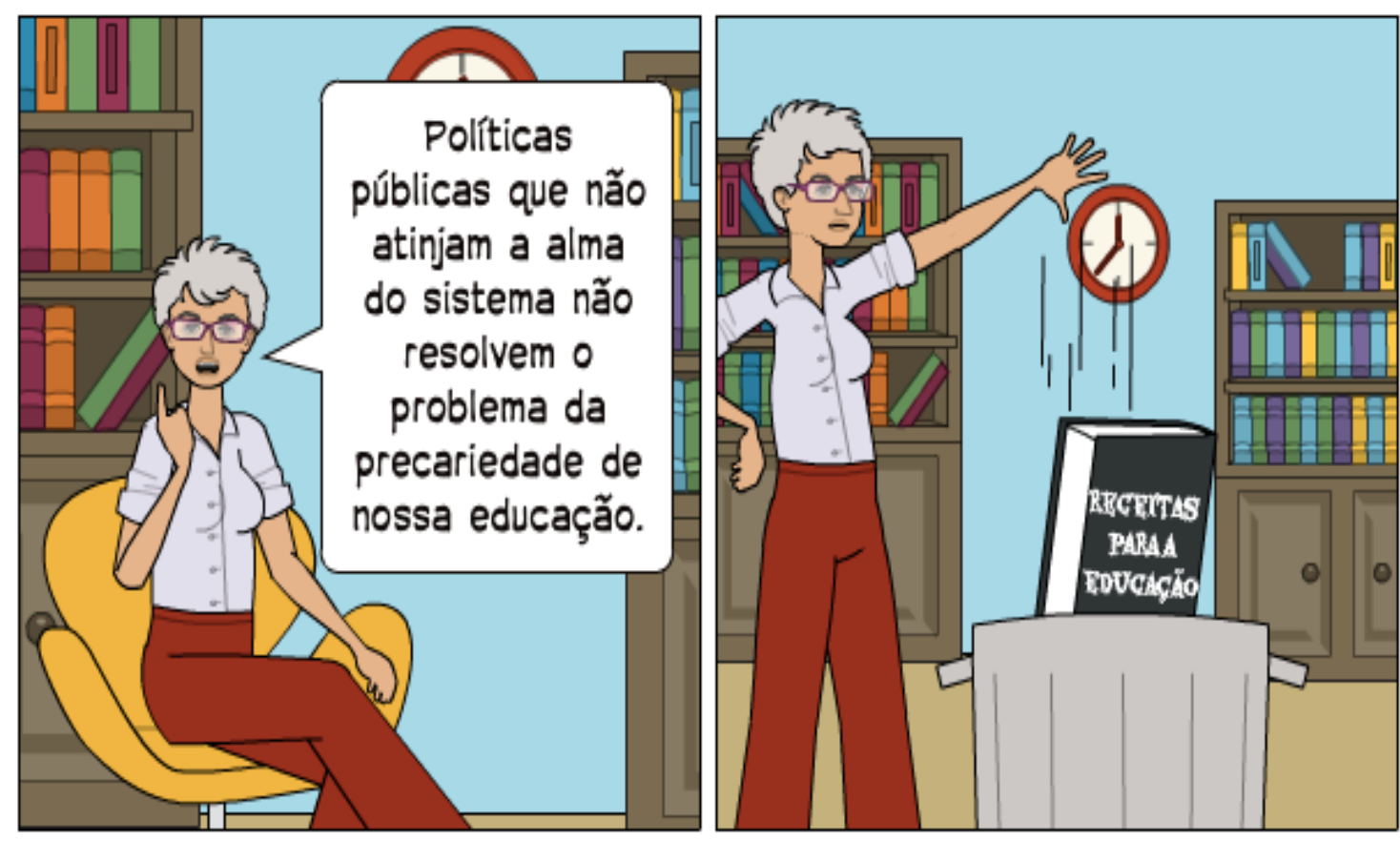


\subsection{Comunicação que é bom, nada}

Nosso trabalho teve início com o interesse em pesquisar resultados de políticas públicas de expansão do ensino superior no Brasil, implementadas principalmente nos últimos dez anos, com ênfase na oferta de ensino público a distância, na ampliação da rede pública de educação superior tecnológica e na combinação dessas duas estratégias.

Acreditávamos que a ausência de transformações qualitativas significantes tanto em áreas estratégicas de formação profissional técnica e tecnológica, quanto na formação superior de professores da educação básica, ainda que com a contribuição de avançadas tecnologias em plataformas de aprendizagem a distância que possibilitam a expansão e a interiorização de vagas em todos os níveis e modalidades de ensino, poderia estar relacionada à frouxa adesão das grandes universidades tradicionais, principalmente as grandes públicas paulistas, a essas políticas públicas de expansão.

Sabíamos que as políticas educacionais ainda refletiam muito a inflexão neoliberal da década de 90 e que, em muitos aspectos, davam continuidade a um projeto educacional que obedece à lógica de flexibilização do capitalismo globalizado. Mas sabíamos também da indiscutível necessidade de expansão do ensino superior público, de valorização do ensino superior tecnológico e de utilização estratégica do ensino a distância como recurso de ampliação de vagas e de possibilidades de formação de professores em nível superior. Buscávamos identificar, então, nos resultados da implementação dessas políticas, aspectos positivos e potencialmente transformadores que pudessem ter sido produzidos e que poderiam ser incrementados caso as grandes universidades tradicionais chamassem para si a condução de todo o processo.

A aproximação com os agentes envolvidos nos eventos investigados, no entanto, revela que as circunstâncias determinantes que estão por detrás do sistema, da estrutura, das ações e políticas educacionais são paralisantes e estão na origem incontornável dos resultados pífios que a educação brasileira apresenta.

A prática pedagógica que vigora nos corações e mentes de quem legisla sobre e de quem atua na educação brasileira está centrada num modelo 
comunicativo de transmissão, não de interação. É o modelo que se adapta a uma concepção elitista de educação que está na origem da insuperável (pelo menos até agora) dualidade do sistema e na dinâmica excludente que se perpetua mesmo quando se implementam políticas de inclusão ou quando se introduzem tecnologias interativas. Porque o modelo comunicativo de transmissão, num contexto de transformações profundas nas formas de produzir e difundir as narrativas que permeiam as relações sociais, tende a cair num vácuo escuro e profundo, exemplarmente representado naquele olhar "descanso de tela" que o estudante ativa para "enfrentar" a maioria das aulas.

O que se vê, por exemplo, no ensino a distância, e está dentro das expectativas de alunos e professores, é a abordagem comunicacional transmissiva. A tecnologia é só um suporte e sua natureza interativa, que faz dela tecnologia de construção de conhecimento, é reduzida a um instrumental básico de interações mínimas já previstas no menu da plataforma de aprendizagem. A participação no fórum de discussões, que poderia ser o momento dialógico por excelência, é uma tarefa penosa e burocrática tanto para o estudante quanto para o professor/tutor. A "interatividade" inclusive está prevista em um cardápio de respostas e participações previamente elaboradas para o professor/tutor, que garante inócuos feedbacks aos alunos que se aventuram a problematizar os temas discutidos.

A cultura reprodutivista e produtivista que vigora em nossa educação, contamina todas as nossas "educações". O ensino a distância não é ruim porque é a distância, mas porque se constrói a partir de uma visão mercantilista e instrumental que se sustenta no modelo de comunicação transmissiva. $O$ ensino

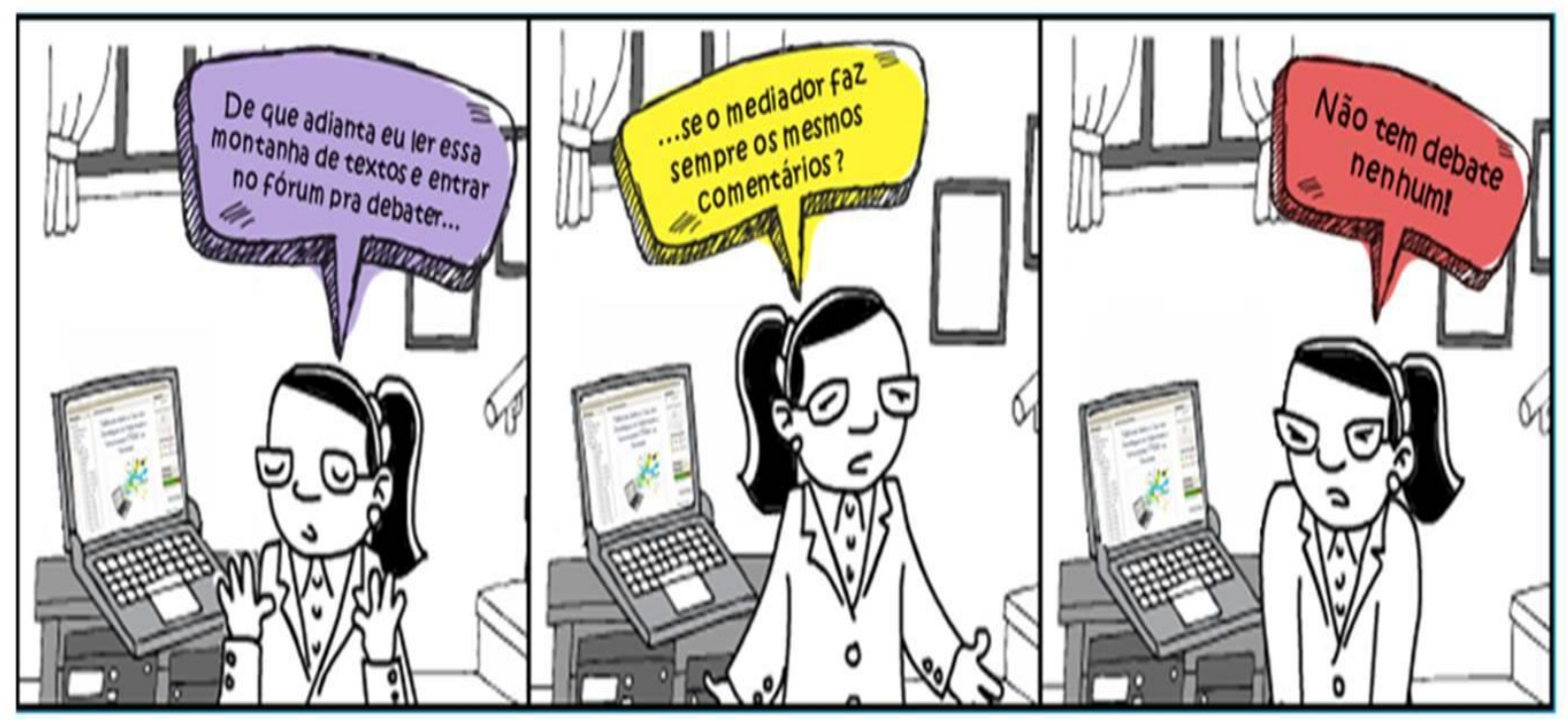


tecnológico não é ruim porque é tecnológico, mas porque também se constrói e se aplica pelo modelo comunicativo-pedagógico tradicional, vertical e autoritário, desprezando o terreno fértil para o ensino problematizador a partir de projetos de pesquisa aplicada.

Não faz muito tempo, um ministro da Educação ${ }^{3}$, ao saber do desempenho de nossos estudantes no PISA ${ }^{4}$, e considerando "a expressiva quantidade das publicações científicas de nossos mestres e doutores", declarou:

A afirmação resultou das observações, no PG, de um desempenho louvável e, na EB, um desempenho "sofrível ou, mesmo, pífio." (MACHADO, 2008)

Esta fratura que o ministro identificou não é pontual, é estrutural e sistêmica. Encontram-se 'inadmissivelmente' apartados no sistema educacional brasileiro o

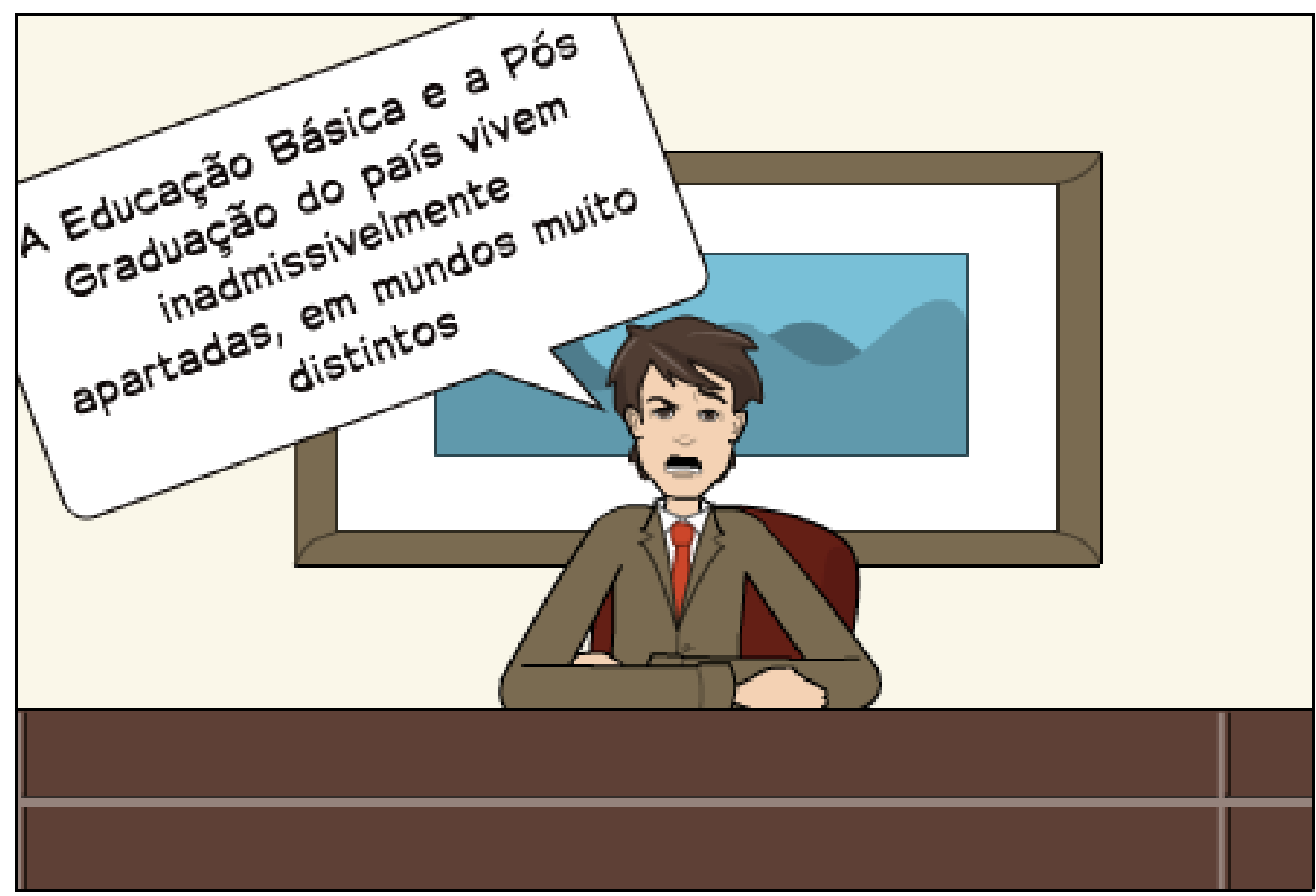

ensino fundamental do ensino médio, o ensino médio do ensino técnico, o ensino superior tradicional do ensino superior tecnológico, a graduação da pós graduação, a pós graduação de todos os níveis e modalidades de ensino, o ensino presencial do ensino a distância, o fazer e o pensar, o mundo da educação do mundo da comunicação, enfim, subsiste entre nós, através dos tempos, um sistema

\footnotetext{
${ }^{3}$ Declaração do Ministro Fernando Haddad, no Ministério da Educação, em Brasília, diante dos 45 coordenadores de área da CAPES que tomaram posse naquele dia - 11 de fevereiro de 2008.

${ }^{4}$ PISA - Program of International Student Assessment.
} 
educacional profundamente marcado por dualidades estruturais (RISTOFF e BIANCHETTI, 2012) que se não pautadas e equacionadas em nossas pesquisas e em nossas políticas públicas, levarão ao fracasso - como o têm feito - todas as iniciativas de expansão das oportunidades educacionais com igualdade, justeza e qualidade, o que pressupõe diálogo, interação e colaboração. 


\subsection{Igual, mas diferente}

Acompanhando tendência global das sociedades pós industriais, o Brasil apresentou forte expansão da demanda e da oferta da educação de nível superior, principalmente a partir da década de 90 do século passado. Ainda em consonância com a tendência global, a educação superior brasileira vive acelerada transição de um modelo de educação superior de elite em direção a um sistema massivo segundo classificação desenvolvida por Martin Trow (2005) -, para o que têm contribuído tanto a adoção de políticas públicas afirmativas, quanto a adoção de programas de educação tecnológica e a distância.

Em aparente contradição a esse contexto, de resto bastante similar ao de outros países desenvolvidos e em desenvolvimento, verifica-se no Brasil a prevalência, tanto nos meios acadêmicos, quanto na sociedade em geral, de um discurso de rejeição às estratégias de ampliação de acesso à educação superior pública, seja em sua vertente de políticas públicas afirmativas, seja em sua vertente de implantação de modalidades não tradicionais de ensino.

Considera-se que o processo de expansão da educação de nível superior no Brasil, ainda que guardadas suas peculiaridades, obedece a uma dinâmica global, já sistematizada por Trow (2005), que analisa o processo vivenciado nas democracias ocidentais pós-industriais, de transição de um sistema de educação superior de elite para um sistema de massas e posteriormente para um sistema universal aberto.
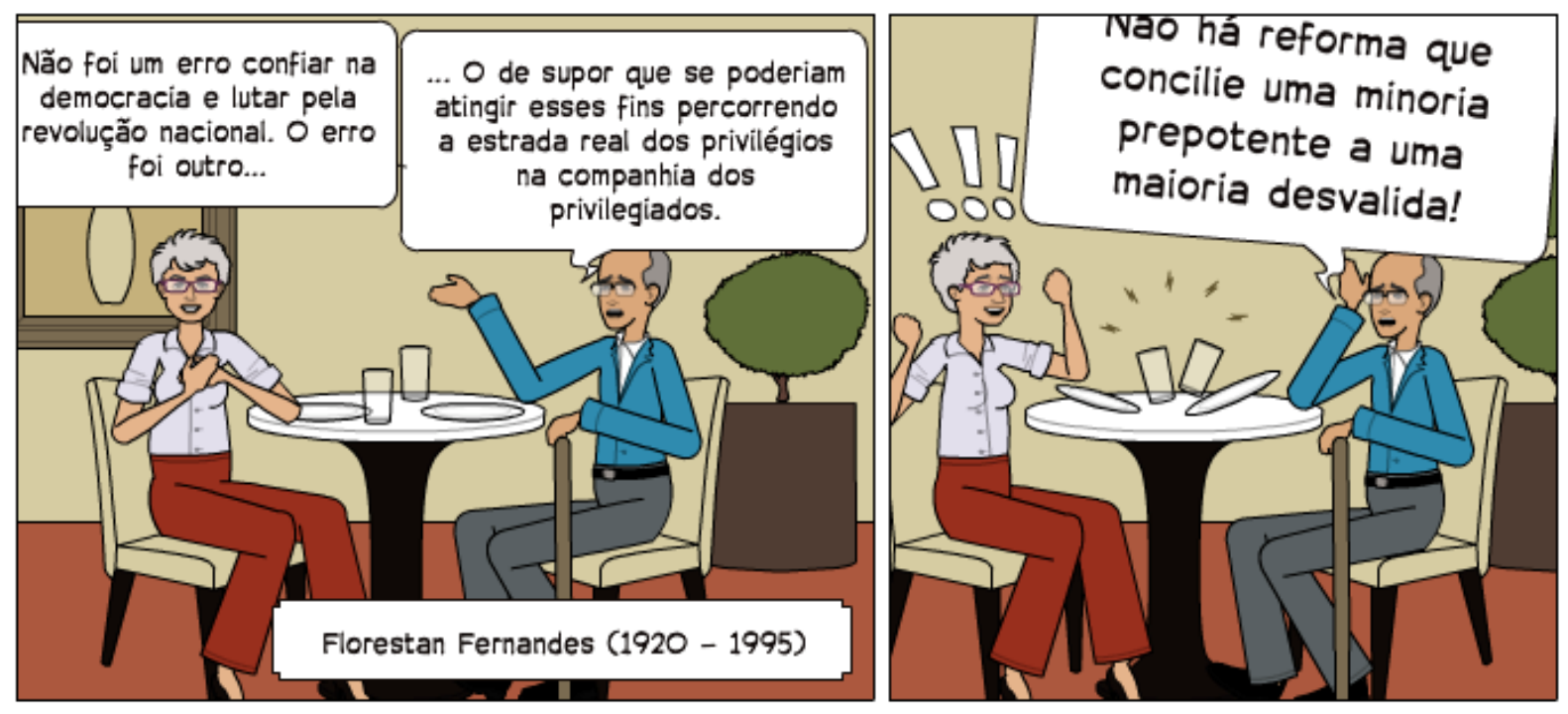
Em sua análise, Trow (2005, pág. 01) classifica os sistemas de ensino superior em três categorias - sistema de elite, taxa líquida de escolarização até $15 \%$; sistema de massa, taxa líquida de 15 a $33 \%$; e sistema universal, com taxa líquida de 33 a $40 \%$ - e descreve as características de cada uma delas:

"(1) Sistema de Elite - formar a mentalidade e o caráter da classe dirigente; preparar para funções e cargos de elite; (2) Sistema de massa - desenvolver habilidades e preparar para um leque mais amplo de funções técnicas e econômicas de elite; (3) Sistema universal - adaptar a 'totalidade da população' às rápidas mudanças tecnológicas e sociais."

A partir dessa descrição, Trow (2005) analisa países como os E.U.A. e a Inglaterra, que já tem características de sistema universal e identifica nos países em desenvolvimento um acelerado processo de expansão da educação superior, em que o sistema massivo vai se constituindo na convivência com uma forte resistência do sistema de elite.

Para análise do contexto brasileiro, muito se utiliza o índice de classificação dos sistemas de educação superior desenvolvido por Martin Trow (2005). Na formulação desse índice de classificação, Trow identifica que, em todos os casos de transição do sistema de elite para o de massas ou o universal, observa-se por um lado, a implementação de políticas públicas afirmativas para garantir o equilíbrio de acesso, e por outro lado, a adoção da educação a distância realizada por meio das tecnologias digitais, como estratégia de flexibilização da rígida estrutura universitária tradicional, a que a maioria dos alunos advindos das classes trabalhadoras não pode atender. 
3 Breve histórico da educação brasileira e seu projeto excludente e elitista 
"Cada fase da historia do ensino brasileiro reflete a interligação desses fatores: a herança cultural, atuando sobre os valores procurados na escola pela demanda social de educação, e o poder político, refletindo o jogo antagônico de forças conservadoras e modernizadoras, com o predomínio das primeiras, acabaram por orientar a expansão do ensino por controlar a organização do sistema educacional de forma bastante defasada em relação às novas e crescentes necessidades do desenvolvimento econômico, este cada vez mais carente de recursos humanos." (ROMANELLI, 1986)

A educação, num contexto mais amplo, abrange diversos conceitos, tais como a cultura, desenvolvimento e demanda social de educação, que são importantes para melhor situar os problemas no sistema educacional.

Neste caso, nossos problemas com relação a educação começam bem antes do que pensávamos, ainda na colonização de nossas terras, quando um povo com alto nível de complexidade cultural inseriu recursos materiais e humanos numa população de diferentes condições de desenvolvimento. Essa transferência de recursos acarretou também mudanças de hábitos de vida diária, ideias, formas de atividade econômica, formas de organização social, política e nas formas de educação.

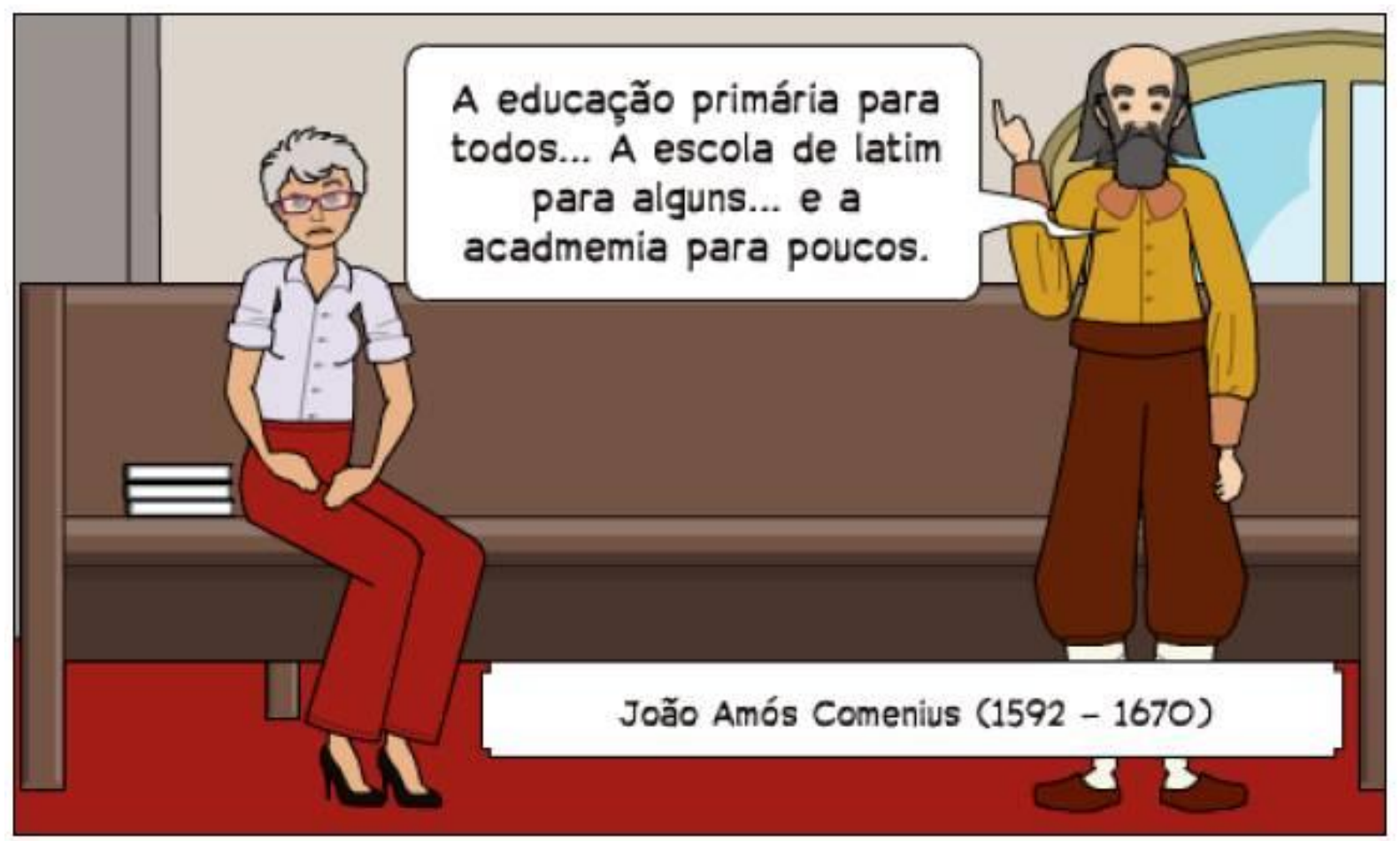


Essas trocas culturais se fizeram das mais diversas formas, e foram aniquiladoras de culturas indígenas, visto que os índios não possuíam condições de integrar aquele novo universo com o qual foram confrontados, baseado em padrões culturais europeus.

"Quando, em 1549, aporta no Brasil, a expedição de Tomé de Sousa, nela estava um grupo de padres jesuítas, liderados por Manuel da Nóbrega (1517 - 1570), com a missão catequizadora e educadora dos filhos dos conquistadores e dos povos autóctones, selvagens que precisavam ser educados e salvos. (...) Nas suas 'bagagens' traziam o firme propósito de em terrae brasilis implantar a Ratio Studiorum, conforme as prescrições emanadas de Roma. Ao chegarem, deparam-se com potenciais 'alunos' que apresentavam defasagens intransponíveis a serem supridas para que o primeiro degrau do esquema original da Ratio, pudesse ser colocado em prática. Manuel da Nóbrega apercebe-se disso e ensaia um plano alternativo ao da Ratio, inserindo uns passos prévios, uns antecedentes, que poderiam ser chamado de 'cursinho supletivo ou preparatório ou compensatório', visando habilitar os 'brasileiros' a encaixarem-se no universal plano prescritivo da Ratio" (RISTOFF e BIANCHETTI, 2012).

Obviamente 'educar' os índios não era tarefa fácil, passar instruções básicas e que rendessem obediência e serventia era muito mais prático e rápido. É neste ponto da história que nasce nosso entrave principal, aqui emerge nossa secular classe dominante, alguns poucos indivíduos que detinham o poder de manipular a maioria desempoderada para os novos padrões impostos.

"Tanto quanto possível as adaptações iam sendo feitas. Naquilo em que o meio se revelou como fator circunstancial mais forte, as adaptações foram mais profundas. Naquilo, porém, em que se revelou menos importante, as acomodações foram mais superficiais, como ocorreu com a chamada cultura letrada. Foi nela que o transplante se revelou mais característico. Os produtos acabados da cultura intelectual são mais facilmente alienáveis. Eles se transportam para o Novo Mundo através da 
camada social dominante, a única em condições de alimentá-los e manipulá-los a seu favor. (...) O controle, domínio e manipulação desses bens ajudaram a manter a dependência cultural da colônia, ao mesmo tempo que conferia status à classe dominante e contribuía para manter a distancia entre esta e as demais camadas sociais" (ROMANELLI, 1986).

A cultura intelectual à mercê das circunstancias alheias acaba gerando formas de comportamento desprovidas de conteúdo e sentido, que se apresentam e transmitem por meio de símbolos vazios de significado, visto que "os bens importados, segregados das circunstâncias em que foram gerados e sem condições de se integrarem naquelas para as quais foram transplantados, ou caem no vazio, ou deturpam-se" (ROMANELLI, 1986). Esse aspecto meramente formal foi a característica dominante da cultura intelectual transplantada desde a época da colonização do Brasil e que se perpetua até os dias de hoje.

Essa herança cultural distorcida, fundada em valores preconizados por 'outro mundo', moldou inclusive as ações de nossas escolas, determinadas a importar os modelos de pensamento e ação pedagógica sem questioná-los ou problematizalos à luz da realidade local. Desta maneira, a escola serve como instrumento da sociedade para impor e preservar a cultura transplantada.

"A forma como foi feita a colonização das terras brasileiras e, mais, a evolução da distribuição do solo, da estratificação social, do controle do poder político, aliadas ao uso de modelos importados de cultura letrada, condicionaram a evolução da educação escolar brasileira" (ROMANELLI, 1986).

O objetivo da educação escolar era manter os desníveis sociais, acentuando as desigualdades à medida que privilegiava as classes dominantes, uma vez que implantou mecanismos de seleção escolar que serviam como uma conquista de 'status' e mantinha-se de maneira precária e insuficiente, com conteúdos culturais que não eram capazes de propiciar às diversas camadas sociais uma preparação eficaz para o trabalho. Completando este quadro temos a predominância do ensino 
de tipo acadêmico, que produzia uma quantidade ainda menor de indivíduos aptos a ingressar em instituições de ensino superior ou técnico.

Essa pirâmide social era encabeçada por um percentual mínimo de uma elite criada, guiada e educada para manipular a seu favor todos os recursos, inclusive culturais e econômicos, mantendo apenas seus descendentes dentro desta 'classe superior'. Assim, "para atender aos interesses das camadas representadas na estrutura do poder, a escola deve concorrer para que somente as camadas dominantes, as únicas em condições de consumir o referido conteúdo, mantenham a sua posição dominante pela natural distância entre essas camadas e os demais estratos sociais, assegurada pelo monopólio da cultura letrada" (ROMANELLI, 1986).

Porém, os métodos utilizados para manter essa desigualdade social eram falhos, visto que não preparavam adequadamente a massa trabalhadora para suas funções, o que ocasionava falta mão de obra qualificada para acompanhar o crescimento econômico que vinha com a industrialização.

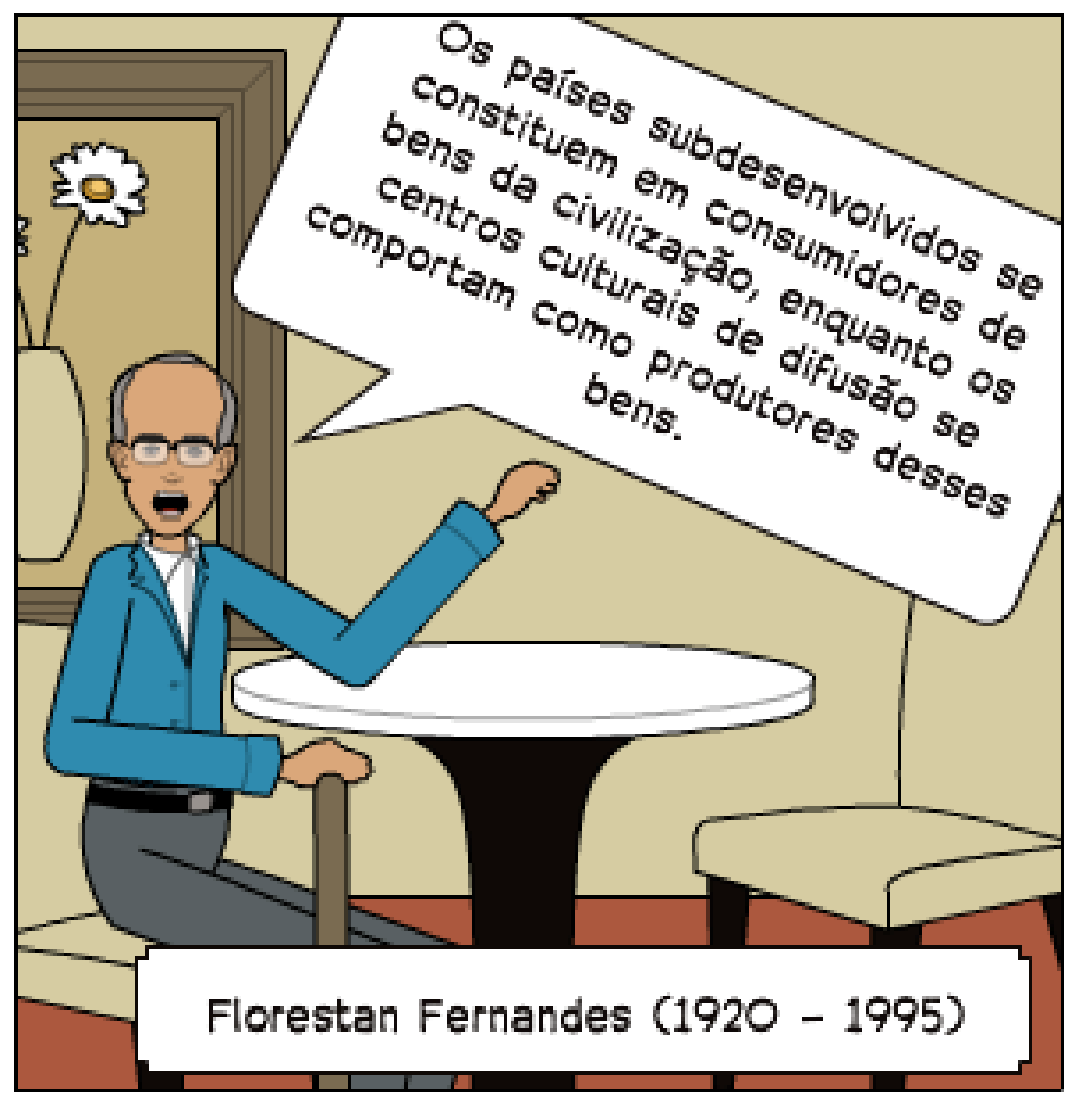



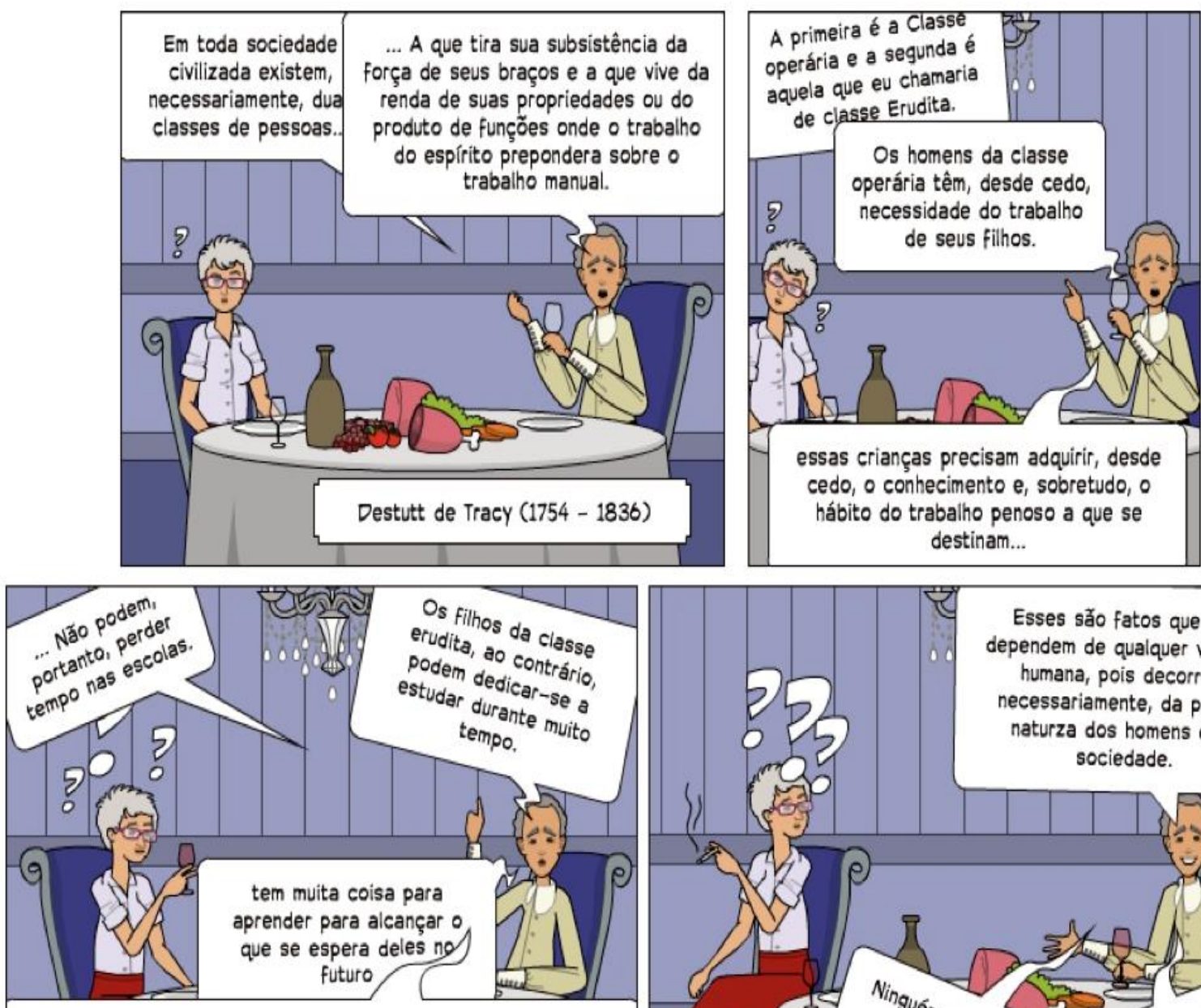

Necessitam de certos tipos de conhecimento que só podem aprender quando $o$ espírito amadurece $e$ atinge determinado grau de desenvolvimento
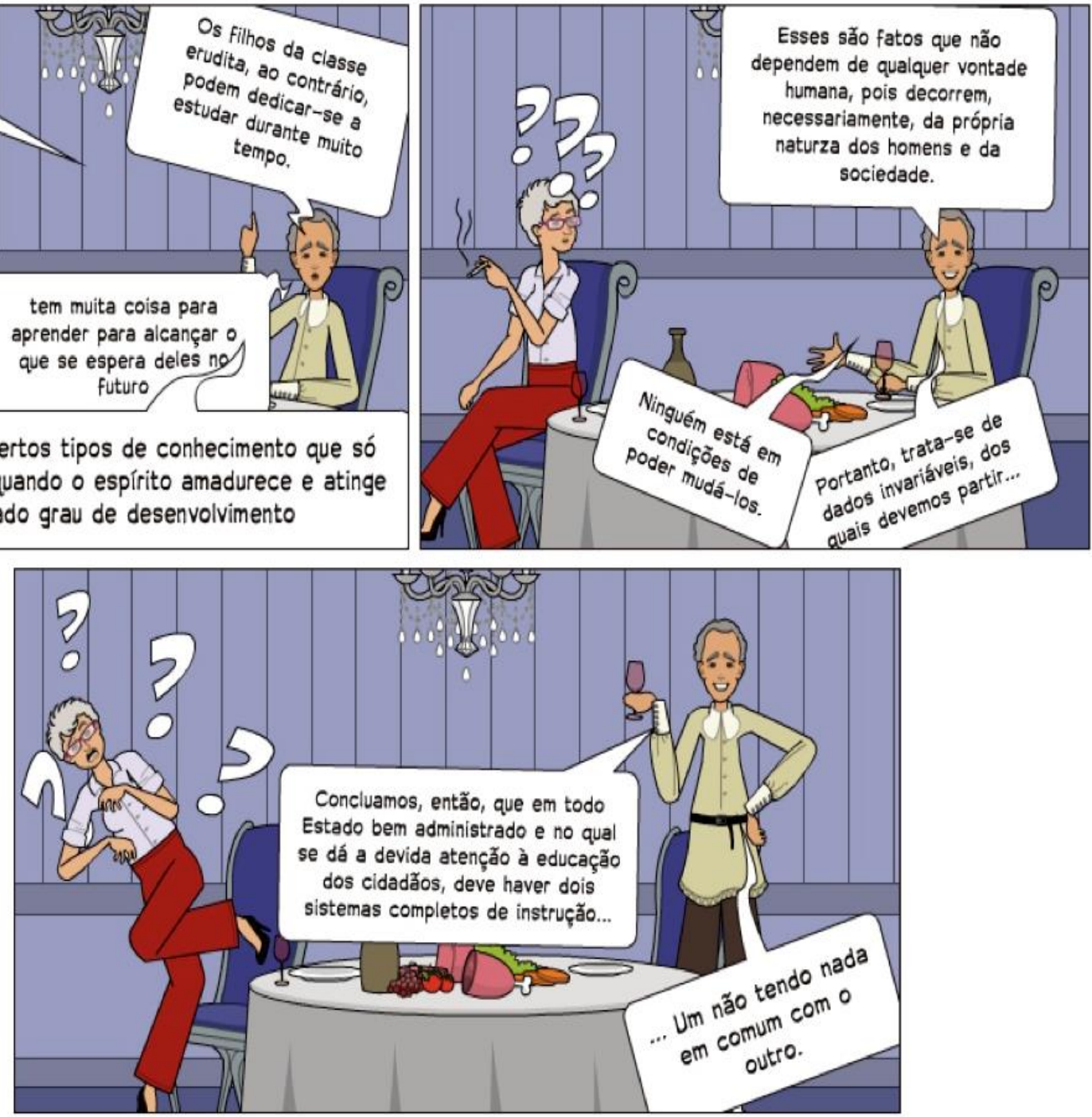
Com a chegada da industrialização somada a nossa conjuntura de país subdesenvolvido o que se tem é o impasse. Ao realizar as mudanças necessárias para se adequar aos novos esquemas preestabelecidos, a educação escolar expõe seu atraso em relação ao desenvolvimento, já que em determinado momento a modernização técnica acaba por exigir um dinamismo maior do sistema de produção e consumo, gerando necessidades cada vez mais urgentes de absorção das camadas sociais não consumidoras, de um lado, e de qualificação de mão de obra, de outro

Assim, quase sempre, a industrialização vem acompanhada da defasagem escolar. O crescimento desordenado e acelerado gera uma pressão sobre a expansão da escolaridade, exigindo uma renovação de seu sistema. No entanto, criamos um sistema de ensino arcaico que foi propositalmente desenvolvido para selecionar uma minoria favorecida, que não quer e não vai abrir mão dos privilégios que os diferenciam, tornando quase impossível a tarefa de preparar a população para a nova realidade.

"O atraso é um fenômeno global que atinge todos os aspectos da vida social: é toda uma estrutura que caminha em desequilíbrio nas sociedades subdesenvolvidas. A percepção desse desequilíbrio também pode fazer-se de forma desigual. $E$ a educação será renovada conforme o prisma através do qual a própria sociedade percebe 0 desequilíbrio. (...) 0 comportamento social consequente é aquele que procura uma forma de adequar a realidade local aos modelos" (ROMANELLI, 1986).

Adequar populações a novas realidades não é uma tarefa difícil apenas para os países subdesenvolvidos, veja-se a chamada "crise mundial", gerada por um desequilíbrio entre as necessidades reais que o desenvolvimento traz para cada país, a demanda social exigida e a oferta de ensino disponível. Essa crise pode se manifestar de diversas maneiras, tudo depende de como a sociedade se vê em relação ao problema e qual atitude é preconizada. 
No Brasil a evolução da educação refletiu a mesma luta travada desde os primórdios, e vimos novamente a tendência em favorecer as facções conservadoras. Assim, a expansão do ensino caracterizou-se por um desequilíbrio nas duas formas de controle: no controle quantitativo - que sofreu uma demanda maior do que a oferta de ensino era capaz de fornecer; e no controle qualitativo com a multiplicação desenfreada de escolas que favoreceu um tipo de ensino que não condizia com as necessidades econômicas de qualificação para o trabalho.

A expansão do ensino acabou não resolvendo os problemas sociais e

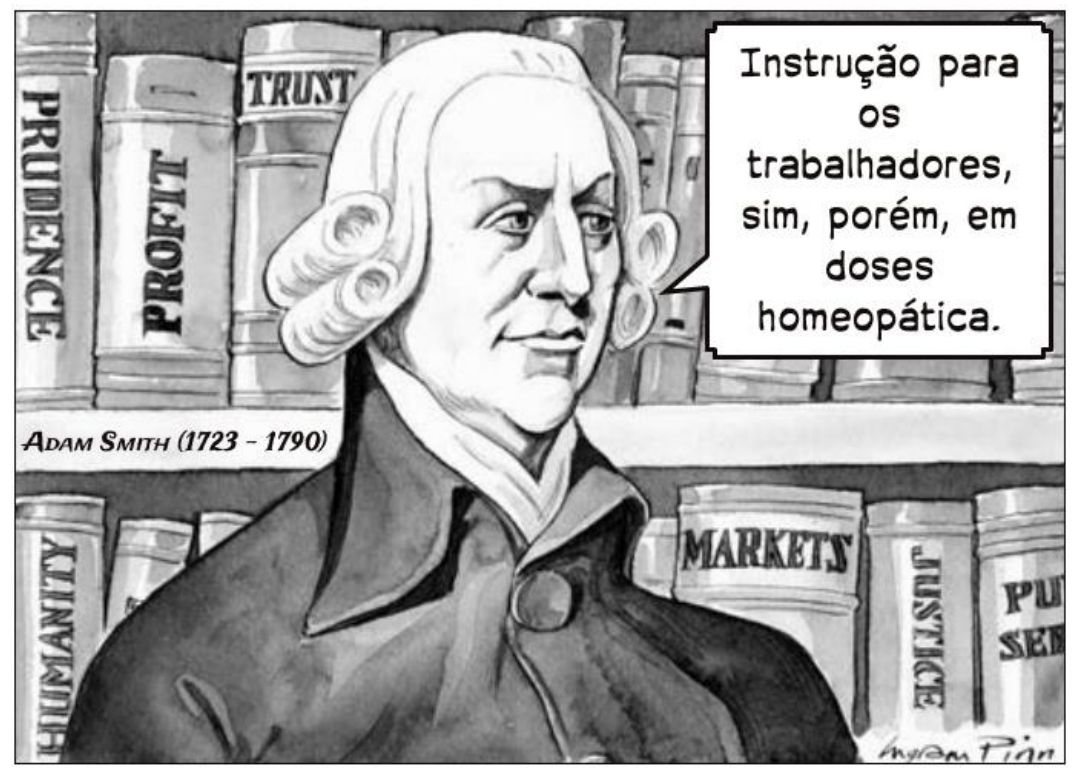

econômicos, pelo contrario, contribuiu para agravá-los. Observa-se então a predominância das formas arcaicas de ensino, protegidas pela necessidade em manter os padrões elitistas da sociedade, enquanto a economia tem que depender de uma mão de obra desqualificada e pouco produtiva.

"Nos países cuja tradição escolar criou um comportamento social favorável à demanda de educação "elitista" e aristocrática, dificilmente o início da industrialização acarreta mudanças na expressão dos interesses sociais pela educação. No caso do Brasil, mais de três séculos de escravidão e patriarcalismo podem ser responsáveis pela criação de uma demanda típica de educação classista.

No Brasil, a partir de 1930, a expansão do ensino acabou por acentuar a defasagem entre educação e desenvolvimento, 
por causa do ritmo e da caracterização da expansão da demanda e, ainda, por causa de fatores de ordem política e econômica. Isso se exprimiu, de um lado, pela falta de oportunidades educativas e, de outro, por um desequilíbrio entre os produtos acabados fornecidos pela escola e as necessidades econômicas de qualificação de recursos humanos" (ROMANELLI, 1986).

O sistema escolar entrou em colapso ao tentar conciliar os aspectos modernos assumidos pelo desenvolvimento e o ainda persistente arcaísmo de certas facções das elites dominantes. A expansão do ensino que se deu é o próprio relato dessa contradição, onde por um lado havia a crescente procura por escolas e oportunidades educacionais, enquanto do outro lado a estrutura escolar não sofria mudanças substanciais para poder oferecer quantitativa e qualitativamente $o$ ensino de que a sociedade necessitava.

Uma serie de conflitos iniciados na década de 20 com auge na Revolução de 30 , é o que constitui a chamada Revolução Brasileira, o que denunciava uma ruptura no sistema oligárquico-rural e implantava uma nova ordem social burguesa, e com ela, a economia industrial capitalista.

Assim, durante o período de 30 a 64, a relação política versus economia encontrou um equilíbrio entre o novo modelo político de tendências populistas e o modelo de expansão da indústria. Chegamos ao impasse quando nos deparamos com a radicalização das posições de direita e esquerda, e o rumo do desenvolvimento precisava tomar partido, escolhendo entre uma revolução social e econômica pró-esquerda ou a inserção da política e da economia totalmente em prol da esfera capitalista.

Assim, o "processo de mercantilização da Educação, iniciada com o economicismo da década de 1960, alterou profundamente a estrutura e a organização educacional brasileira. Esse processo percorreu gerações e instaurouse em todos os governos que posteriormente assumiram o poder" (SANTOS et al, 2012).

"A partir da década de 1960, os programas de pósgraduação em Educação e as faculdades de Educação tiveram 
um forte apelo economicista, tanto nas teorias educacionais quanto nas políticas públicas. Como efeito, houve o desmantelamento da escola pública e o reforço da educação como negócio. (...) Muitos eventos abalaram o sistema sócioeducacional brasileiro. Dentre alguns, podemos citar: a promulgação da $1^{\text {a }}$ Lei de Diretrizes e Bases da Educação Nacional (LDB, Lei 4.024/61); debates, reivindicações e lutas no campo político-social, contra a ideologia de desenvolvimento então vigente, que colocava a escola como responsável pela formação da mão-de-obra preparada, visando o 'desenvolvimento' do país; golpe militar de 1964; e a figura do educador Paulo Freire, trazendo à luz de novos ideais seu método de alfabetização. Pode-se afirmar que o período foi de muita disputa no campo político e social" (SANTOS et al, 2012).

No Brasil da década de 1990, as reformas educacionais mantêm em linhas

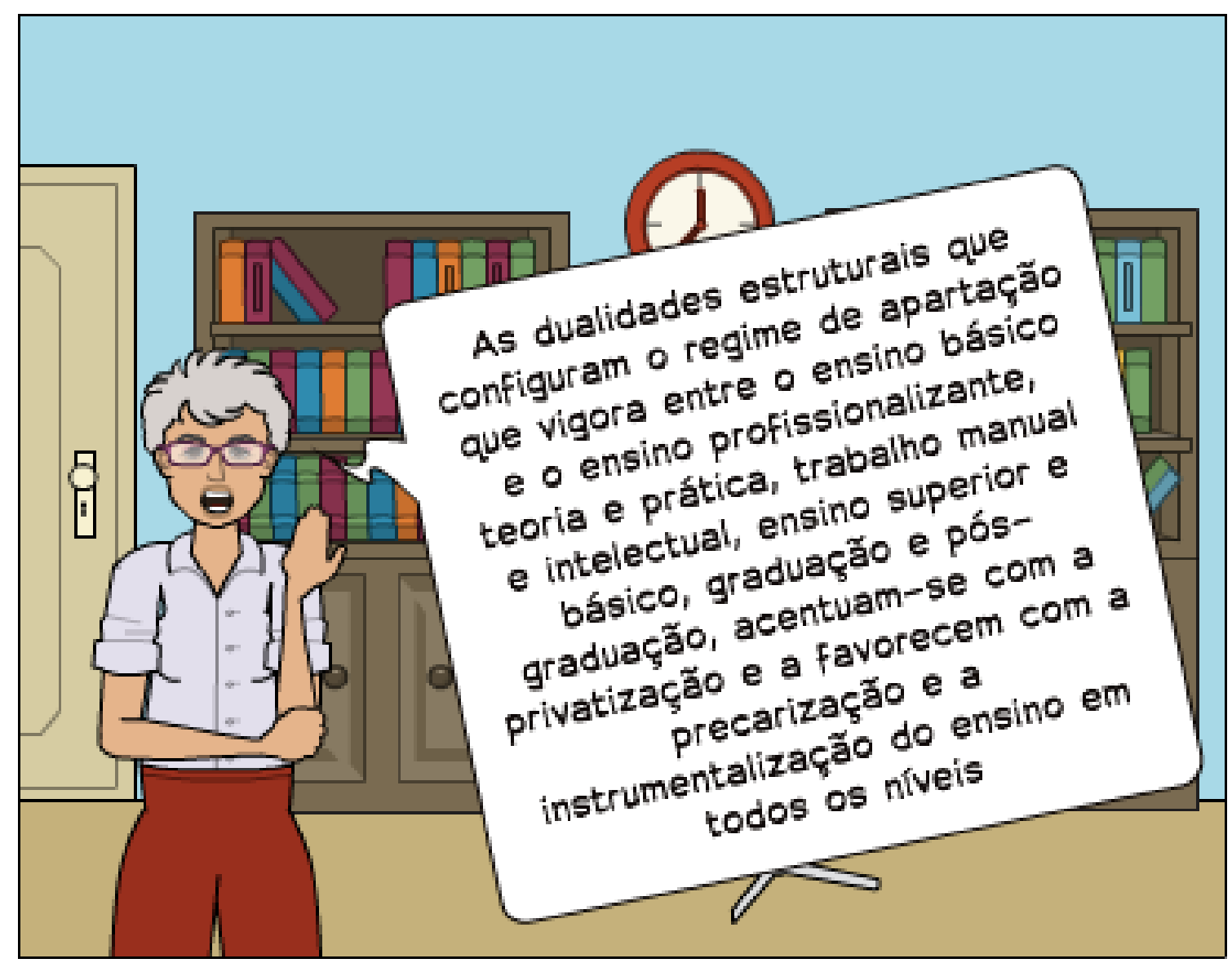

gerais o projeto que vigorava desde a colônia. A ênfase na expansão do ensino superior, que se deu pela receita neoliberal com o aumento do número de vagas e 
de matrículas no ensino privado, foi a marca do início da transição do sistema brasileiro de educação superior de elite - que, em linhas gerais, ainda perdura -, para um sistema de massas.

"As interlocuções entre a pós-graduação (PG) e a educação básica (EB) caracterizam-se como (des)encontros históricos e que, no limite, vêm garantindo a manutenção do apartheid socioeducacional desde o Brasil Colônia. A primazia da opção pela educação das elites e a inexistência ou postergação de iniciativas voltadas à educação popular é uma marca dessa trajetória. (...) Desde os primórdios, sempre se optou e foram mais eficazes as iniciativas para dar conta das necessidades educacionais daqueles que se encontravam/am no ápice da pirâmide social, do que àqueles que se situavam/am nos estratos intermediários e muito menos para o grande contingente que compõe a base da pirâmide." (RISTOFF e BIANCHETTI, 2012)

Nesse contexto de expansão privada da educação superior surgiram os primeiros cursos superiores a distância, em geral, voltados à formação profissional técnica específica e à licenciatura, atendendo a demandas urgentes do mercado, principalmente, do aquecido mercado da educação.

Os governos pós-neoliberais, a partir de 2002, dão sequência ao projeto de expansão da educação superior, consolidam políticas públicas de incentivo à iniciativa privada - como o PROUNI - e abrem nova e importante frente, por meio de estratégias de ampliação de vagas públicas nas universidades federais e pela criação da Universidade Aberta do Brasil (UAB), bem como pela implantação de um sistema universal de certificação de ensino médio e acesso ao ensino superior - o ENEM. 


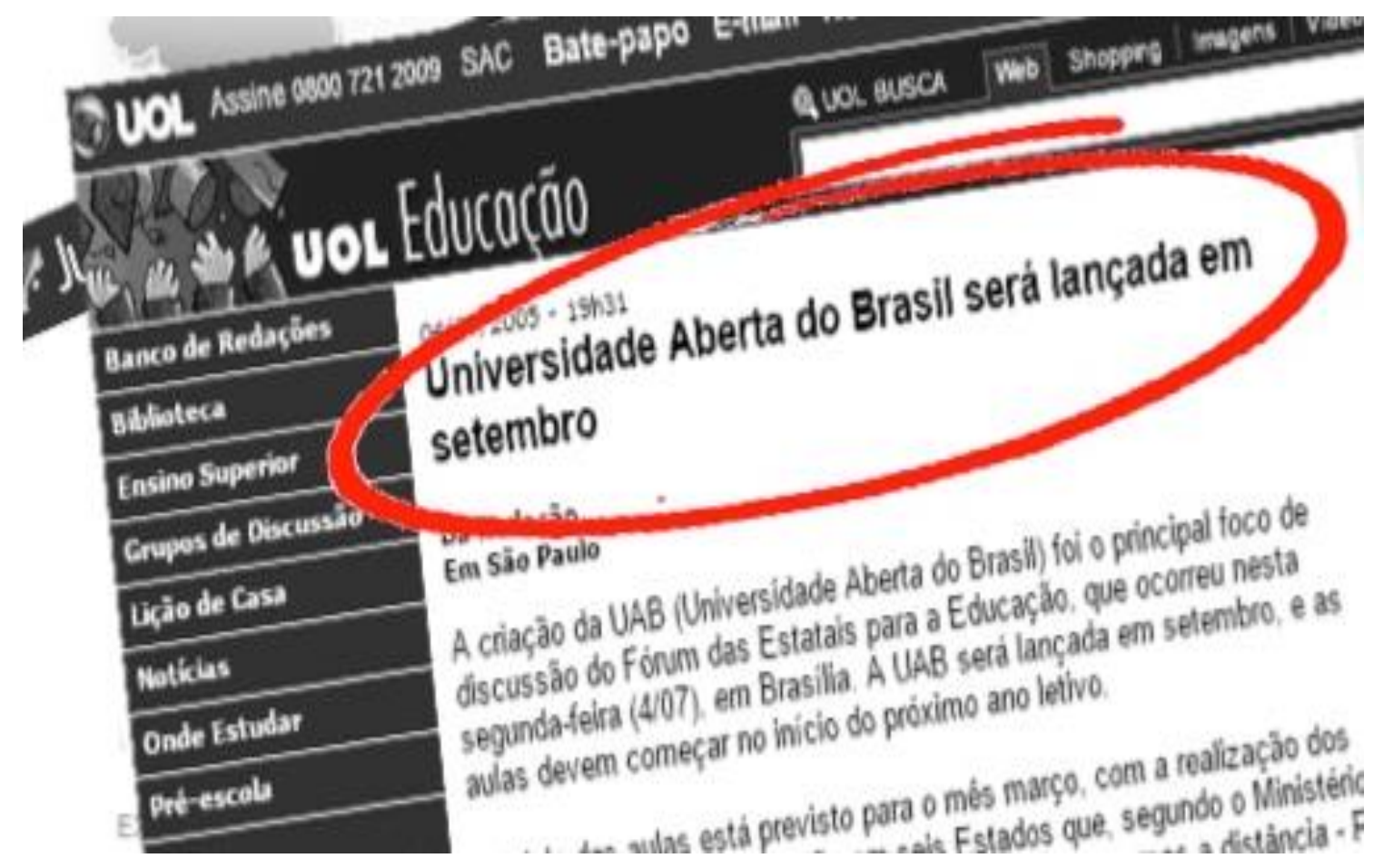

Desde a segunda metade do século XX, registra-se globalmente acelerada expansão da demanda e da oferta de educação de nível superior, em função de características históricas das sociedades pós-industriais. A ampliação do acesso à educação de nível superior implica alteração da estrutura e da função das universidades; coloca em questão o papel tradicional desempenhado pelas instituições e seus profissionais; e impõe profunda reflexão sobre formação profissional, formação acadêmica e produção do conhecimento a partir de uma matriz de características menos elitistas.

Verifica-se que a expansão da educação de nível superior tem se dado historicamente pela adoção de medidas de promoção de igualdade de oportunidades, em geral, via políticas públicas afirmativas e via políticas públicas educacionais que desenham novas formas de instituições e de cursos superiores, menos atrelados à rigidez da estrutura tradicional universitária.

Nesse contexto, a educação a distância tem sido ferramenta importante para a expansão do ensino de nível superior, principalmente por meio das chamadas Universidades Abertas que tiveram acentuado impulso das tecnologias digitais de comunicação e informação. 


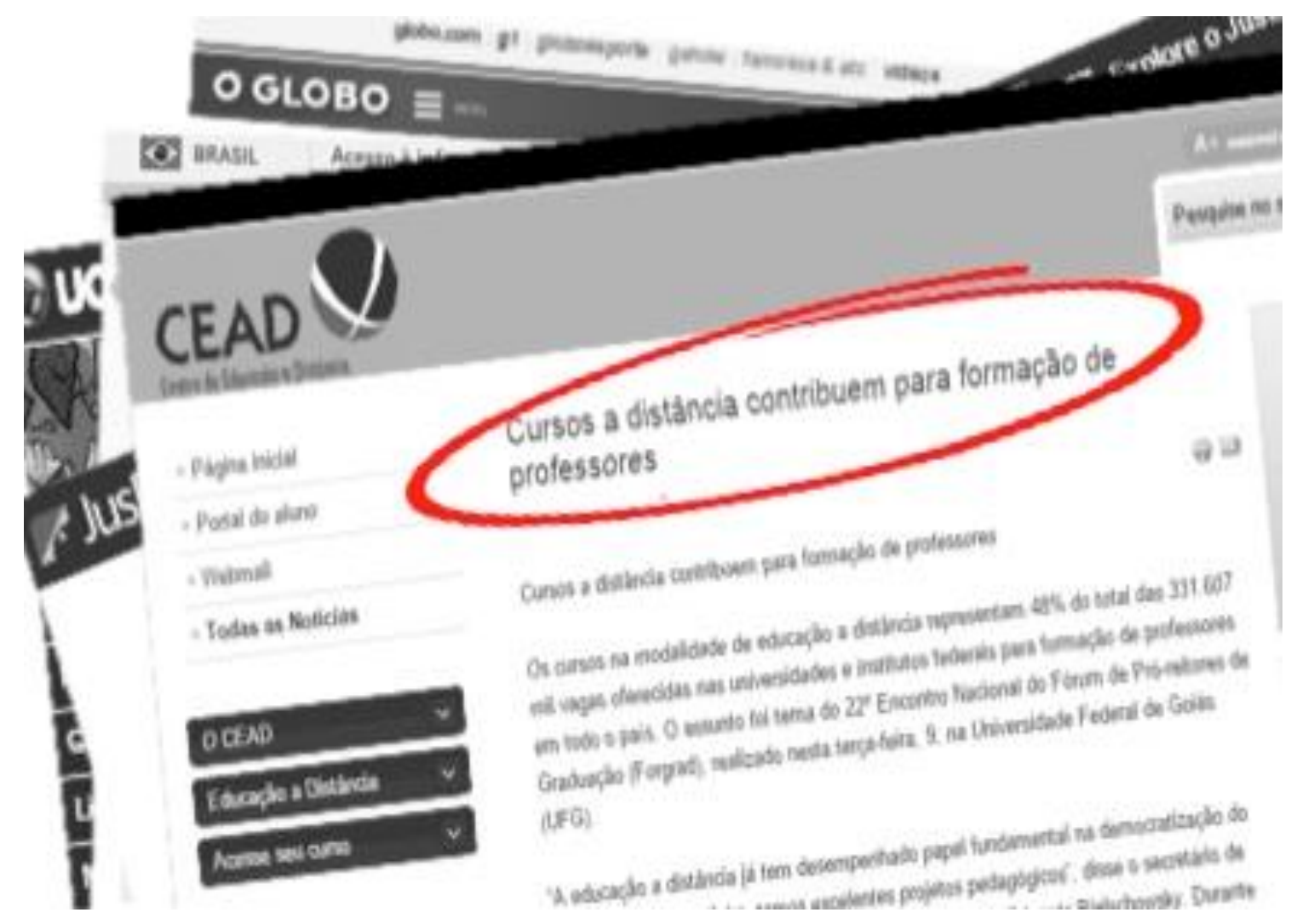

Alguns países, que já se encontram em estágio avançado de transição para sistemas universais de educação superior (TROW, 2005), superaram seus fechados sistemas de educação de elite com a adoção, mesmo pelas instituições de forte apego à tradição, de cursos abertos massivos a distância, que passaram a compor, juntamente com os cursos presenciais, alternativas de formação de nível universitário.

O Brasil, guardadas suas peculiaridades, tem acompanhado a tendência global e registrado forte expansão da demanda e da oferta de educação de nível superior, principalmente a partir da década de 1990, como se pode verificar nos dados das tabelas da sequência deste trabalho.

No caso brasileiro, a transição de um sistema de educação superior de elite para um sistema de educação superior de massas, dá-se, sem dúvida, por um lado, pela pressão das demandas sociais por acesso e igualdade de oportunidades, mas, por outro, por conta do ideário neoliberal, com amplo incentivo do governo à iniciativa privada, que constituiu no Brasil um dos mais fortes mercados para as grandes corporações do setor educacional, como também pode ser comprovado nos números das tabelas que virão mais adiante. 
Além do incentivo à iniciativa privada no que diz respeito à abertura e ampliação de cursos e instituições de nível superior, a implantação de programas de ensino a distância foi fortemente estimulada com sua inclusão na Lei de Diretrizes e Bases, de 1996.

Ao contrário do que ocorreu nas instituições privadas, foram tímidas as iniciativas de expansão de vagas públicas de ensino superior a distância e a tônica dessas iniciativas foram os cursos de formação de professores e as licenciaturas. A criação da Universidade Virtual Pública do Brasil - a UniREDE -, em 1999, e da Universidade Aberta do Brasil - a UAB -, em 2005, responderia, em sentido amplo, à demanda por ampliação, democratização e interiorização da oferta de vagas públicas de ensino superior, mas atende, em sentido estrito, à urgência de formação de professores para as redes públicas municipais, estaduais e federal.

O contexto em que se constatam os fatos acima descritos, permite que se afirme, então, que a estrutura elitista que caracteriza a educação superior brasileira passou a viver, desde fins do século passado, um processo de transição para uma estrutura massiva que vem se consolidando por meio de políticas públicas de ampliação do acesso ao ensino superior, conforme registram os últimos censos

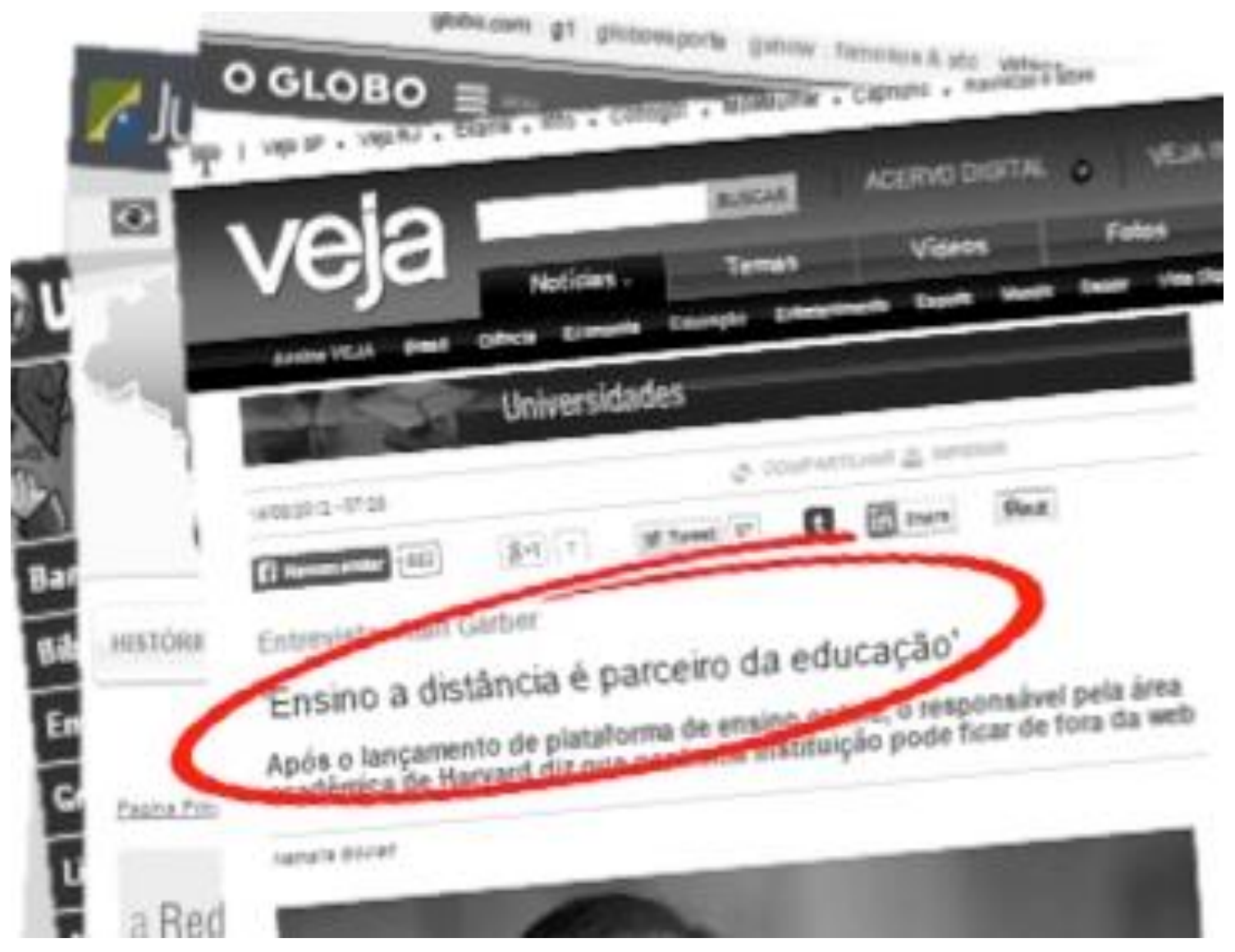


realizados pelo Ministério da Educação e Cultura, tanto no que diz respeito à evolução do número de vagas e de matrículas no ensino superior presencial e a distância, quanto no que se refere ao número de ingressantes em instituições privadas com bolsas subsidiadas pelo Programa Universidade Para Todos PROUNI. (MEC - Censo 2010)

A universalização da educação superior no Brasil ainda é desafio longínquo e difícil, principalmente devido às profundas desigualdades socioeconômicas que todavia marcam a realidade brasileira e que foram acentuadamente aprofundadas por 21 anos de ditadura militar, sucedidos por 18 anos de governos civis atrelados à doutrina neoliberal, que produziram, entre outras mazelas, as condições de precarização que configuram a educação brasileira em todos os níveis.

$\mathrm{E}$, assim como é indiscutível que o país se encontra em pleno processo de consolidação de uma estrutura massiva de educação superior, também o é, que a massificação desse nível de educação aqui se deu principalmente pelas vias da empresa privada, tanto no que diz respeito à educação de modalidade presencial quanto à de modalidade a distância. Esta última, inclusive, sendo fortemente responsável pelo significativo crescimento de vagas e matrículas no ensino universitário brasileiro.

Diante disso, é premente que a Universidade reedite um diálogo ativo com as questões da Educação no Brasil se quisermos que esse processo de crescimento e massificação se reverta em experiência democrática de emancipação, por meio de oferta pública e gratuita de formação escolar de qualidade em todos os níveis. 
4 Alguns números da educação superior brasileira segundo os números do censo de 2013:

$$
\begin{array}{r}
\text { O difícil combate à educação elitista e } \\
\text { privatista }
\end{array}
$$


Os números do último censo da Educação Superior reforçam as características da expansão que teve início na década de 90 do século passado, de caráter acentuadamente privatista, como podemos observar no Gráfico 1, onde vemos que até o ano de 1997 o número de instituições de ensino mantinha-se relativamente estável, começando a sofrer alterações drásticas em seu cenário a partir de 1998, quando ocorreu o primeiro grande salto na quantidade e na proporção entre as categorias pública e privada, com o surgimento de 75 novas instituições particulares. Os anos seguintes continuaram com essa transformação, em 2006 nossa porcentagem era de 10,9\% de instituições públicas contra 89,1\% privadas.

Gráfico 1 - Evolução do Número de Instituições de Educação Superior, por Categoria Administrativa - Brasil 1995-2013

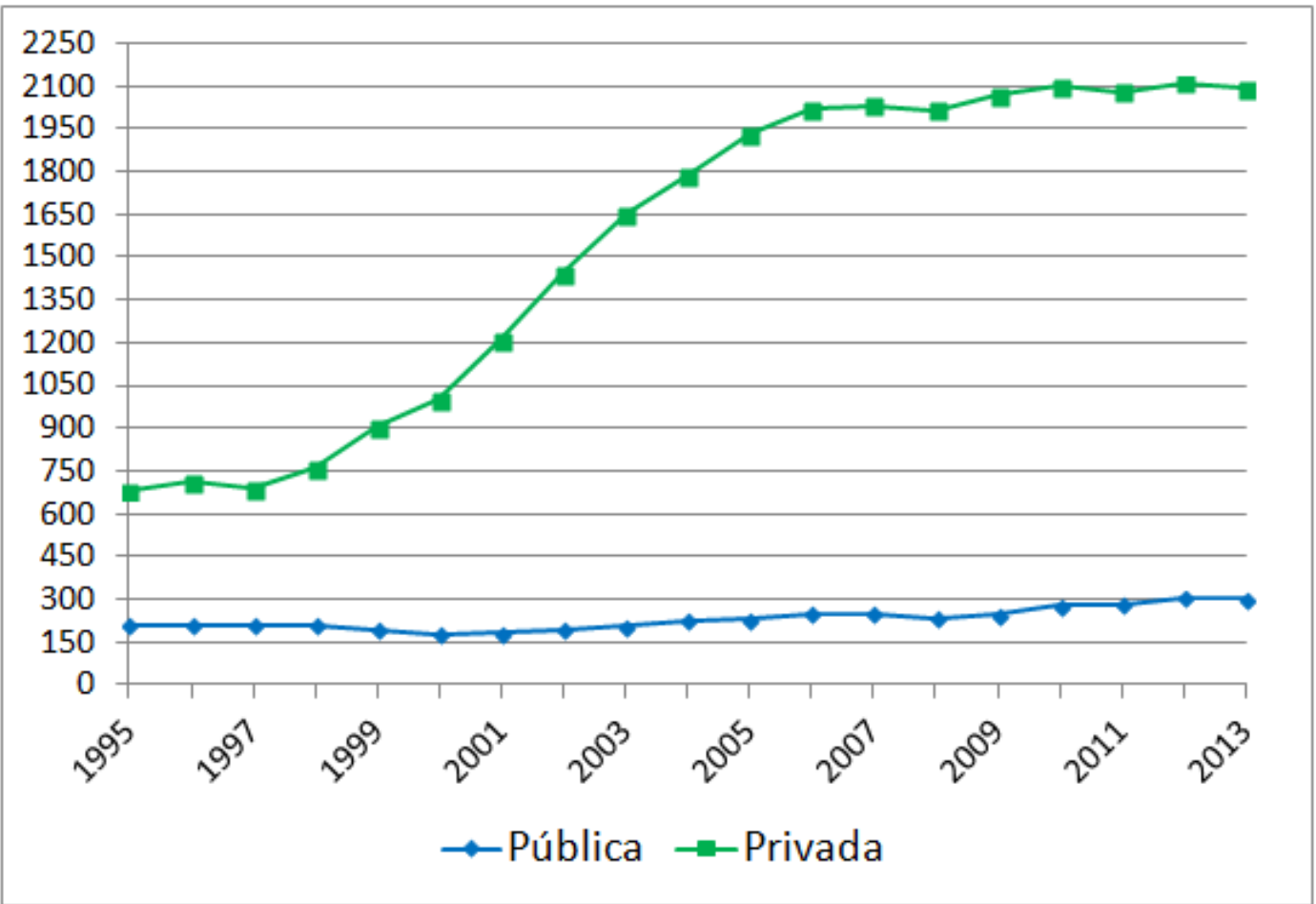

Fonte: Fonte: MEC/Inep 
A partir de 2007, o número de instituições de ensino particulares começou a se estabilizar, com alguns altos e baixos - os altos sempre superando os baixos -, enquanto as instituições públicas seguiram com um leve crescimento; e assim, chegamos a 2013 com 12,6\% de instituições públicas contra 87,4\% privadas.

Essa discrepância na distribuição por categoria administrativa das

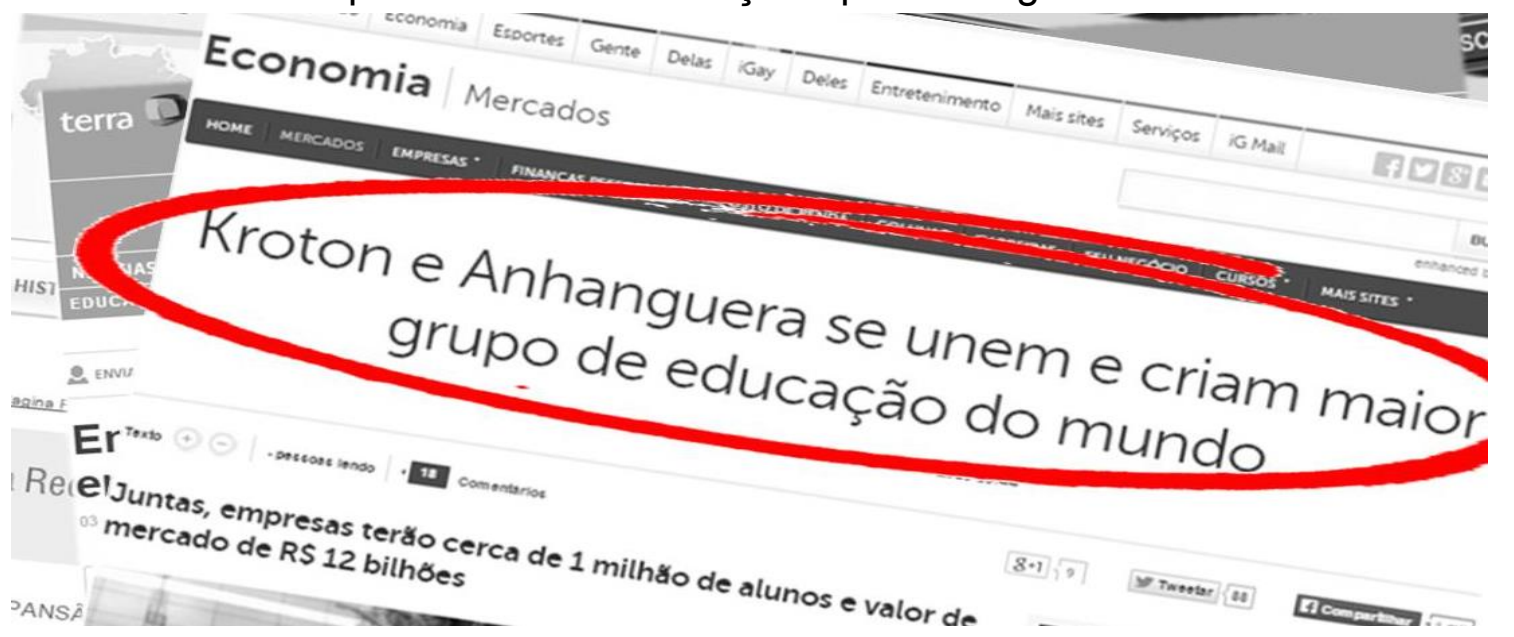

Instituições de Ensino Superior no país no ano de 2013, esta ilustrada no Gráfico 2.

Gráfico 2 - Número de Instituições de Educação Superior, por Categoria Administrativa das IES - 2013

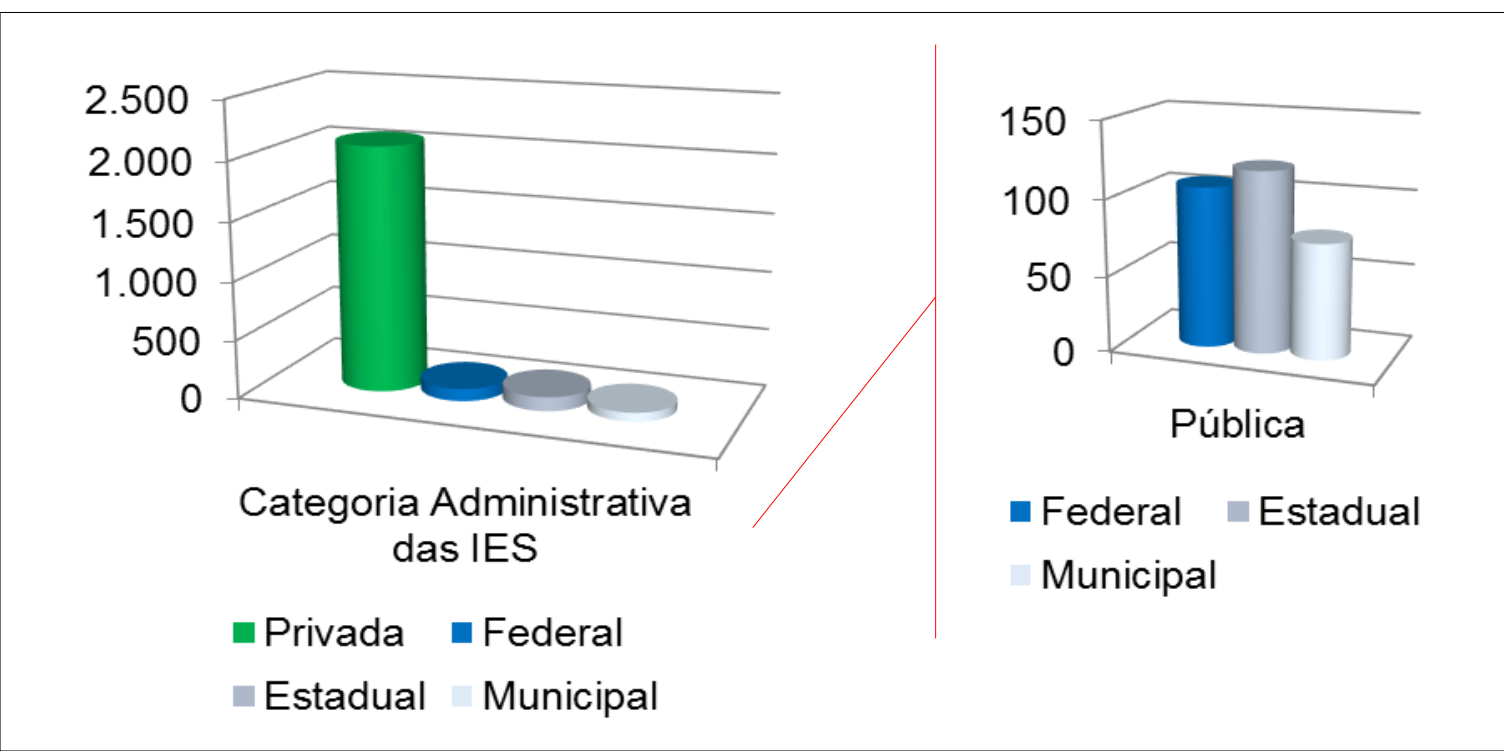

Fonte: Fonte: MEC/Inep 
Nesse quadro histórico, de 1995 a 2013, as instituições de ensino públicas tiveram um crescimento de $71 \%$, enquanto as privadas cresceram $205 \%$, o que torna inegável o caráter privatista na expansão do ensino superior brasileiro.

Avaliando mais detalhadamente o número de instituições de educação superior no ano de 2013, representamos na Tabela 1 sua distribuição regional por categoria administrativa. Dentre as 301 instituições públicas no Brasil, 98 encontram-se em capitais enquanto 203 estão no interior; o mesmo perfil é visto nas instituições privadas, com maior distribuição no interior, onde das 2090 unidades existentes no país, 743 estão nas capitais enquanto 1347 encontram-se no interior. Essa distribuição regional por categoria administrativa está ilustrada no Gráfico 3.

Gráfico 3 - Número de Instituições de Educação Superior, por Localização (Capital e Interior), segundo a Categoria Administrativa das IES - 2013

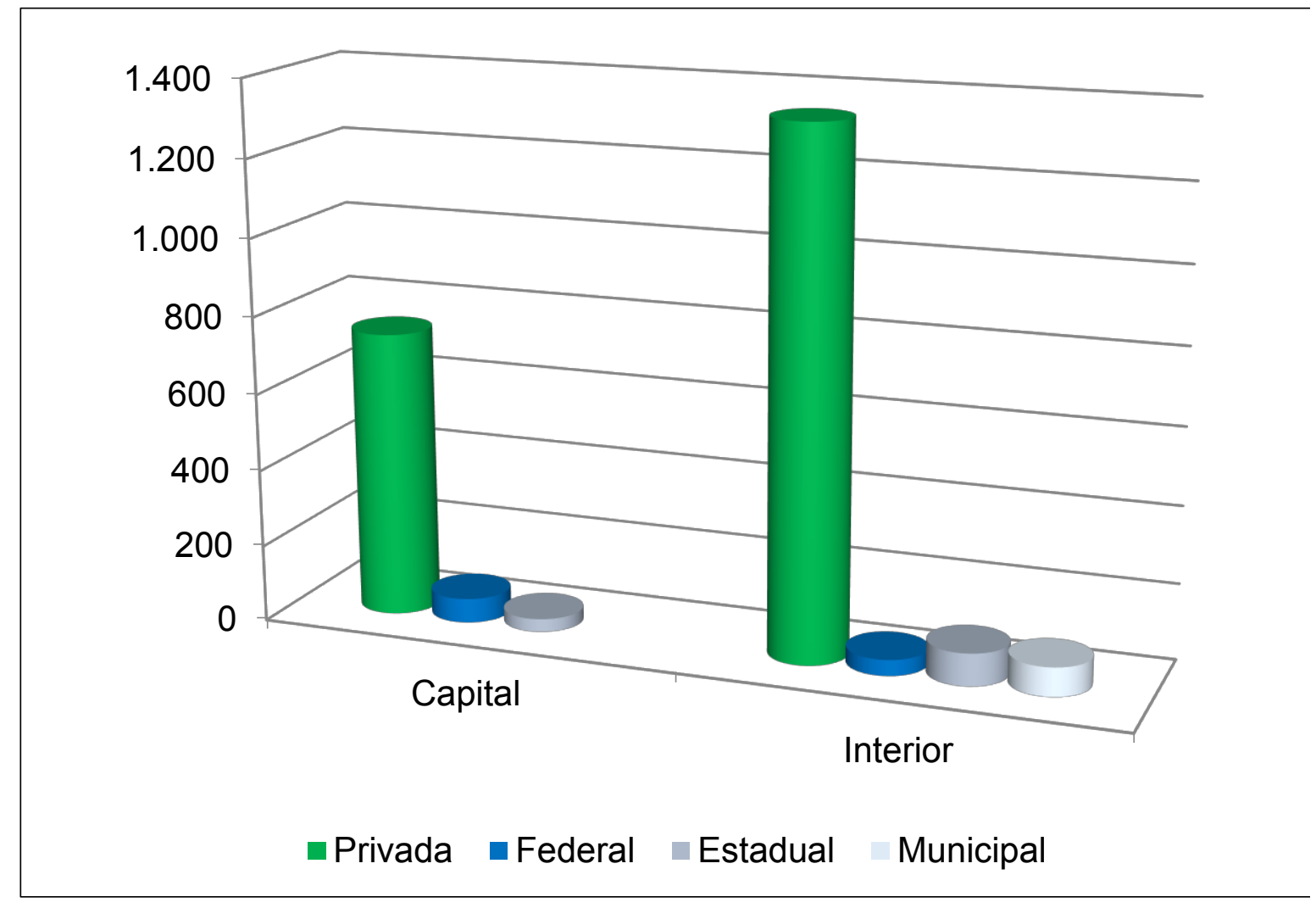

Fonte: Fonte: MEC/Inep 


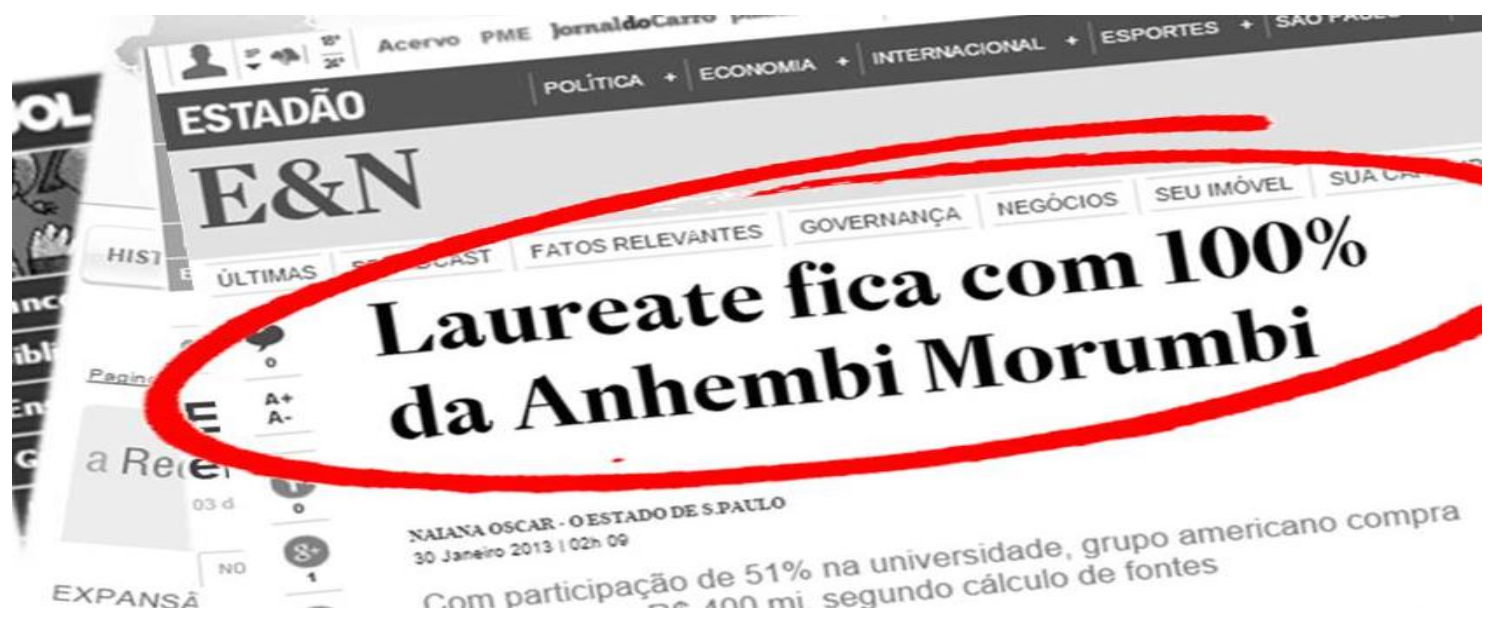

Desmembrando a categoria pública, observamos que sua maioria é representada pelas instituições estaduais $(39,53 \%)$, seguida das federais $(35,22 \%)$ e municipais (25,25\%). Dentre essas, o mesmo padrão de distribuição é encontrado, exceto nas instituições federais, onde $60,38 \%$ pertencem as capitais contra $39,62 \%$ do interior; já nas estaduais temos $28,57 \%$ nas capitais e $71,43 \%$ no interior, e nas municipais $100 \%$ encontram-se no interior.

Tabela 1 - Número de Instituições de Educação Superior, por Localização (Capital e Interior), segundo a Categoria Administrativa das IES - 2013

\begin{tabular}{ccccccc}
\hline Categoria & \multicolumn{2}{c}{ Total } & \multicolumn{2}{c}{ Capital } & \multicolumn{2}{c}{ Interior } \\
\cline { 2 - 7 } Administrativa & $\mathbf{N}$ & $\%$ & $\mathbf{N}$ & $\%$ & $\mathbf{N}$ & $\%$ \\
\hline Brasil & 2.391 & 100 & 841 & 35,17 & 1.550 & 64,83 \\
Pública & 301 & 12,6 & 98 & 32,56 & 203 & 67,44 \\
Federal & 106 & 35,22 & 64 & 60,38 & 42 & 39,62 \\
Estadual & 119 & 39,53 & 34 & 28,57 & 85 & 71,43 \\
Municipal & 76 & 25,25 & - & - & 76 & 100 \\
Privada & 2.090 & 87,4 & 743 & 35,55 & 1.347 & 64,45 \\
\hline
\end{tabular}

Fonte: Fonte: MEC/Inep

Aprofundando um pouco mais, podemos avaliar nossos dados por organização acadêmica, como vemos na Tabela 2. $\mathrm{Na}$ distribuição entre universidades, centros universitários, faculdades e IF/CEFET (Instituto Federal de Educação, Ciência e Tecnologia e Centro Federal de Educação Tecnológica), encontramos um predomínio das faculdades, com $84,32 \%$ do total de todas as 
instituições de ensino superior do Brasil; dentre estas, 140 são públicas e 1876 privadas. Seguindo em ordem decrescente, as universidades vêm em segundo lugar, com 8,16\%, sendo 111 públicas e 84 privadas, destoando do padrão geral com predomínio de instituições privadas; em terceiro lugar vem os centros universitários, com 5,85\% constituído de 10 públicas e 130 privadas; em quarto lugar os IF/CEFET's, com 1,67\%, sendo todas públicas (federais).

Tabela 2 - Número de Instituições de Educação Superior, por Organização Acadêmica e Localização (Capital e Interior), segundo a Categoria Administrativa das IES - 2013

\begin{tabular}{|c|c|c|c|c|c|c|}
\hline \multirow{3}{*}{$\begin{array}{l}\text { Categoria } \\
\text { Administrativa }\end{array}$} & \multicolumn{6}{|c|}{ Instituições } \\
\hline & \multicolumn{3}{|c|}{ Universidades } & \multicolumn{3}{|c|}{$\begin{array}{c}\text { Centros } \\
\text { Universitários } \\
\end{array}$} \\
\hline & Total & Capital & Interior & Total & Capital & Interior \\
\hline Brasil & 195 & 87 & 108 & 140 & 54 & 86 \\
\hline Pública & 111 & 49 & 62 & 10 & 1 & 9 \\
\hline Federal & 62 & 31 & 31 & - & - & - \\
\hline Estadual & 38 & 18 & 20 & 1 & 1 & - \\
\hline Municipal & 11 & - & 11 & 9 & - & 9 \\
\hline Privada & 84 & 38 & 46 & 130 & 53 & 77 \\
\hline \multirow{3}{*}{$\begin{array}{l}\text { Categoria } \\
\text { Administrativa }\end{array}$} & \multicolumn{6}{|c|}{ Instituições } \\
\hline & \multicolumn{3}{|c|}{ Faculdades } & \multicolumn{3}{|c|}{ IF e CEFET } \\
\hline & Total & Capital & Interior & Total & Capital & Interior \\
\hline Brasil & 2.016 & 670 & 1.346 & 40 & 30 & 10 \\
\hline Pública & 140 & 18 & 122 & 40 & 30 & 10 \\
\hline Federal & 4 & 3 & 1 & 40 & 30 & 10 \\
\hline Estadual & 80 & 15 & 65 & - & - & - \\
\hline Municipal & 56 & & 56 & - & - & - \\
\hline Privada & 1.876 & 652 & 1.224 & - & - & - \\
\hline
\end{tabular}

Fonte: Fonte: MEC/Inep

No que diz respeito ao número de cursos, matriculas, concluintes e ingressos, o predomínio se mantém nas instituições de ensino privado, reflexo do número exacerbado que encontramos de instituições pelo país. Essas distribuições, por grau acadêmico e categoria administrativa, podem ser 
observadas na Tabela 3, onde o número de cursos tem $66,15 \%$ de seu total representado por instituições privadas contra 33,85\% de públicas; as matriculas chegam a $73,55 \%$ nas instituições privadas contra $26,45 \%$ nas públicas; consequentemente temos $76,86 \%$ de concluintes nas privadas contra 23,14 nas públicas; quanto aos ingressos temos um percentual de $80,61 \%$ nas instituições privadas contra $19,39 \%$ nas públicas.

Tabela 3 - Número de Cursos, Matrículas, Concluintes e Ingressos em Cursos de Graduação - Presenciais e a Distância, por Grau Acadêmico (Bacharelado, Licenciatura, Tecnólogo e Não Aplicável), segundo a Categoria Administrativa

\begin{tabular}{|c|c|c|c|c|c|c|}
\hline \multicolumn{7}{|c|}{ das IES - 2013} \\
\hline \multirow{3}{*}{$\begin{array}{l}\text { Cursos / Matrículas / } \\
\text { Concluintes / } \\
\text { Ingressos / Categoria } \\
\text { Administrativa }\end{array}$} & \multicolumn{6}{|c|}{ Total Geral } \\
\hline & \multicolumn{2}{|c|}{ Total } & \multirow{2}{*}{ Bacharelado } & \multirow{2}{*}{ Licenciatura } & \multirow{2}{*}{ Tecnólogo } & \multirow{2}{*}{$\begin{array}{c}\text { Não } \\
\text { Aplicável }\end{array}$} \\
\hline & $\mathbf{N}$ & $\%$ & & & & \\
\hline $\begin{array}{l}\text { Número de } \\
\text { Cursos }\end{array}$ & 32.049 & 100 & 17.905 & 7.920 & 6.224 & - \\
\hline Pública & 10.850 & 33,85 & 5.339 & 4.365 & 1.146 & - \\
\hline Federal & 5.968 & - & 3.259 & 2.118 & 591 & - \\
\hline Estadual & 3.656 & - & 1.365 & 1.874 & 417 & - \\
\hline Municipal & 1.226 & - & 715 & 373 & 138 & - \\
\hline Privada & 21.199 & 66,15 & 12.566 & 3.555 & 5.078 & - \\
\hline Matrículas & 7.305 .977 & 100 & 4.912 .310 & 1.374 .174 & 995.746 & 23.747 \\
\hline Pública & 1.932 .527 & 26,45 & 1.166 .489 & 599.718 & 143.169 & 23.151 \\
\hline Federal & 1.137 .851 & - & 735.407 & 328.694 & 61.975 & 11.775 \\
\hline Estadual & 604.517 & - & 287.712 & 238.106 & 67.323 & 11.376 \\
\hline Municipal & 190.159 & - & 143.370 & 32.918 & 13.871 & - \\
\hline Privada & 5.373 .450 & 73,55 & 3.745 .821 & 774.456 & 852.577 & 596 \\
\hline Concluintes & 991.010 & 100 & 594.695 & 201.353 & 194.962 & - \\
\hline Pública & 229.278 & 23,14 & 139.891 & 71.149 & 18.238 & - \\
\hline Federal & 115.336 & - & 75.300 & 33.453 & 6.583 & - \\
\hline Estadual & 82.892 & - & 43.457 & 31.208 & 8.227 & - \\
\hline Municipal & 31.050 & - & 21.134 & 6.488 & 3.428 & - \\
\hline Privada & 761.732 & 76,86 & 454.804 & 130.204 & 176.724 & - \\
\hline Ingressos & 2.742 .950 & 100 & 1.738 .272 & 469.237 & 521.766 & 13.675 \\
\hline Pública & 531.846 & 19,39 & 309.384 & 153.372 & 55.766 & 13.324 \\
\hline Federal & 325.267 & - & 200.840 & 91.410 & 23.794 & 9.223 \\
\hline Estadual & 142.842 & - & 62.937 & 50.921 & 24.883 & 4.101 \\
\hline Municipal & 63.737 & - & 45.607 & 11.041 & 7.089 & - \\
\hline Privada & 2.211 .104 & 80,61 & 1.428 .888 & 315.865 & 466.000 & 351 \\
\hline
\end{tabular}

Fonte: Fonte: MEC/Inep 
Segundo os dados encontrados, o predomínio das instituições privadas só não ocorre na oferta de cursos de licenciatura, onde encontramos 4365 (55,11\%) cursos oferecidos por instituições públicas contra 3555 (44,89\%) nas privadas.

$\mathrm{Na}$ Tabela 4 temos as mesmas categorias representadas, porém agora avaliamos apenas as Instituições de Ensino Superior a Distância. Os números da educação superior a distância acentuam ainda mais a disparidade entre a oferta do sistema privado e a do sistema público e mostram como essa 'modalidade' foi significativa para o projeto de privatização do ensino superior contemplado pelas políticas neoliberais dos anos 90 . As potencialidades das avançadas tecnologias digitais para uma expansão includente do ensino superior foram reduzidas à operacionalidade da redução de custos e otimização de lucros para a indústria educacional, com a consequente precarização do ensino e da profissão docente.

Tabela 4 - Número de Polos, Ingressos Totais, Matrículas e Concluintes, nos Cursos de Graduação a Distância, por Categoria Administrativa das IES - 2013

\begin{tabular}{|c|c|c|c|c|c|c|c|c|}
\hline \multirow{3}{*}{$\begin{array}{c}\text { Categoria } \\
\text { Administrativa }\end{array}$} & \multicolumn{8}{|c|}{ Graduação a Distância } \\
\hline & \multicolumn{2}{|c|}{$\begin{array}{l}\text { Número } \\
\text { de Polo }\end{array}$} & \multicolumn{2}{|c|}{$\begin{array}{l}\text { Ingressos } \\
\text { Totais }\end{array}$} & \multicolumn{2}{|c|}{ Matrículas } & \multicolumn{2}{|c|}{ Concluintes } \\
\hline & $\mathbf{N}$ & $\%$ & $\mathbf{N}$ & $\%$ & $\mathbf{N}$ & $\%$ & $\mathbf{N}$ & $\%$ \\
\hline Brasil & $\begin{array}{c}5.32 \\
7\end{array}$ & 100 & $\begin{array}{c}515.40 \\
5\end{array}$ & 100 & $\begin{array}{c}1.153 .57 \\
2\end{array}$ & 100 & 161.072 & 100 \\
\hline Pública & $\begin{array}{c}1.50 \\
1\end{array}$ & $\begin{array}{c}28, \\
2\end{array}$ & 36.906 & 7,2 & 154.553 & $\begin{array}{c}13 \\
4\end{array}$ & 23.017 & 14,3 \\
\hline Federal & 934 & $\begin{array}{r}62, \\
2\end{array}$ & 26.064 & $\begin{array}{r}70, \\
6\end{array}$ & 92.344 & $\begin{array}{r}59, \\
7\end{array}$ & 7.544 & 32,8 \\
\hline Estadual & 354 & $\begin{array}{r}23, \\
6\end{array}$ & 3.218 & 8,7 & 46.929 & $\begin{array}{r}30, \\
4\end{array}$ & 12.744 & 55,3 \\
\hline Municipal & 213 & $\begin{array}{r}14, \\
2\end{array}$ & 7.624 & $\begin{array}{r}20 \\
7\end{array}$ & 15.280 & 9,9 & 2.729 & 11,9 \\
\hline Privada & $\begin{array}{c}3.82 \\
6\end{array}$ & $\begin{array}{c}71, \\
8\end{array}$ & $\begin{array}{c}478.49 \\
9\end{array}$ & $\begin{array}{c}92 \\
8\end{array}$ & 999.019 & $\begin{array}{c}86, \\
6\end{array}$ & 138.055 & 85,7 \\
\hline
\end{tabular}

Fonte: Fonte: MEC/Inep 
Os números observados na educação a distância reforçam distorções preocupantes. No Brasil, dos 5327 polos de ensino a distância $71,8 \%$ são de instituições privadas, contra 28,2 de públicas; nos ingressos totais chegamos a $92,8 \%$ nas instituições privadas contra $7,2 \%$ nas públicas; as instituições privadas representam $86,6 \%$ das matriculas, contra $13,4 \%$ nas públicas; e consequentemente temos $85,7 \%$ de concluintes em instituições privadas, contra 14,3\% em públicas. Esses dados estão ilustrados nos Gráficos 4 a 7 .

Gráfico 4 - Número de Polos nos Cursos de Graduação a Distância, por Categoria Administrativa das IES - 2013

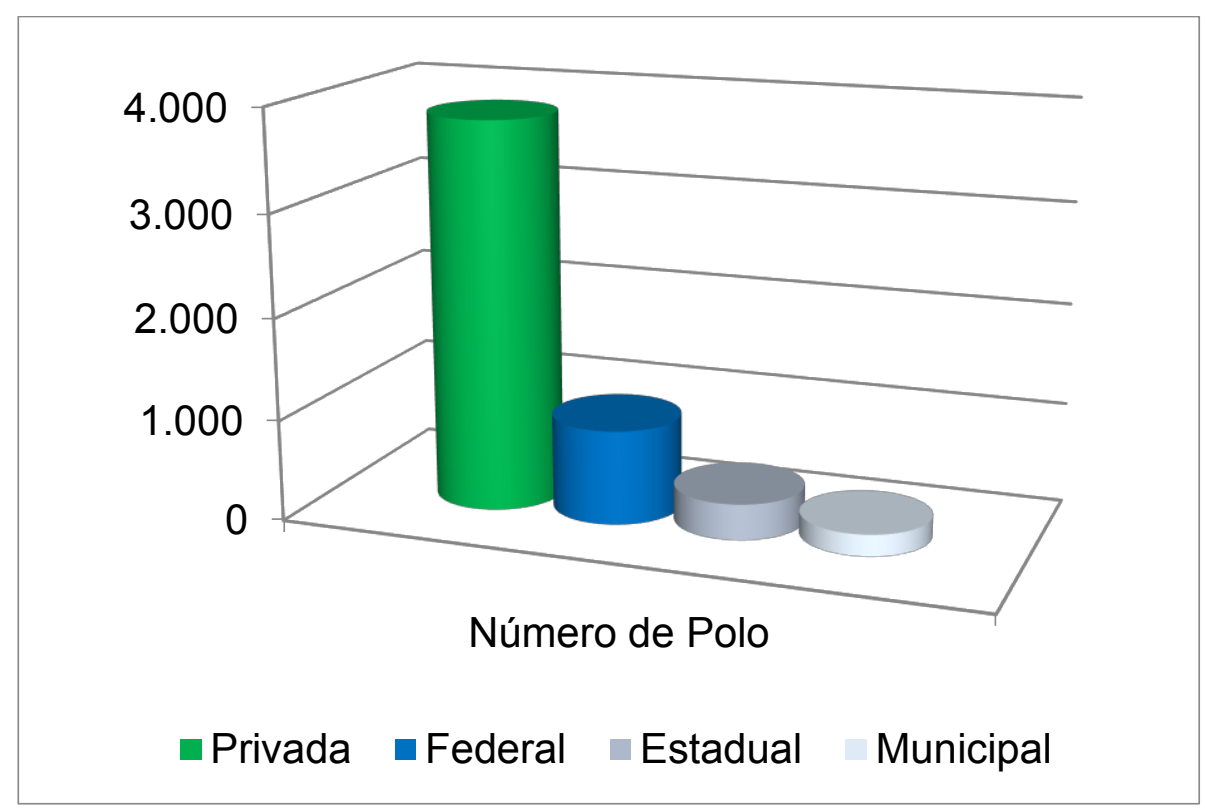

Fonte: Fonte: MEC/Inep

Gráfico 5 - Ingressos Totais nos Cursos de Graduação a Distância, por Categoria Administrativa das IES - 2013 


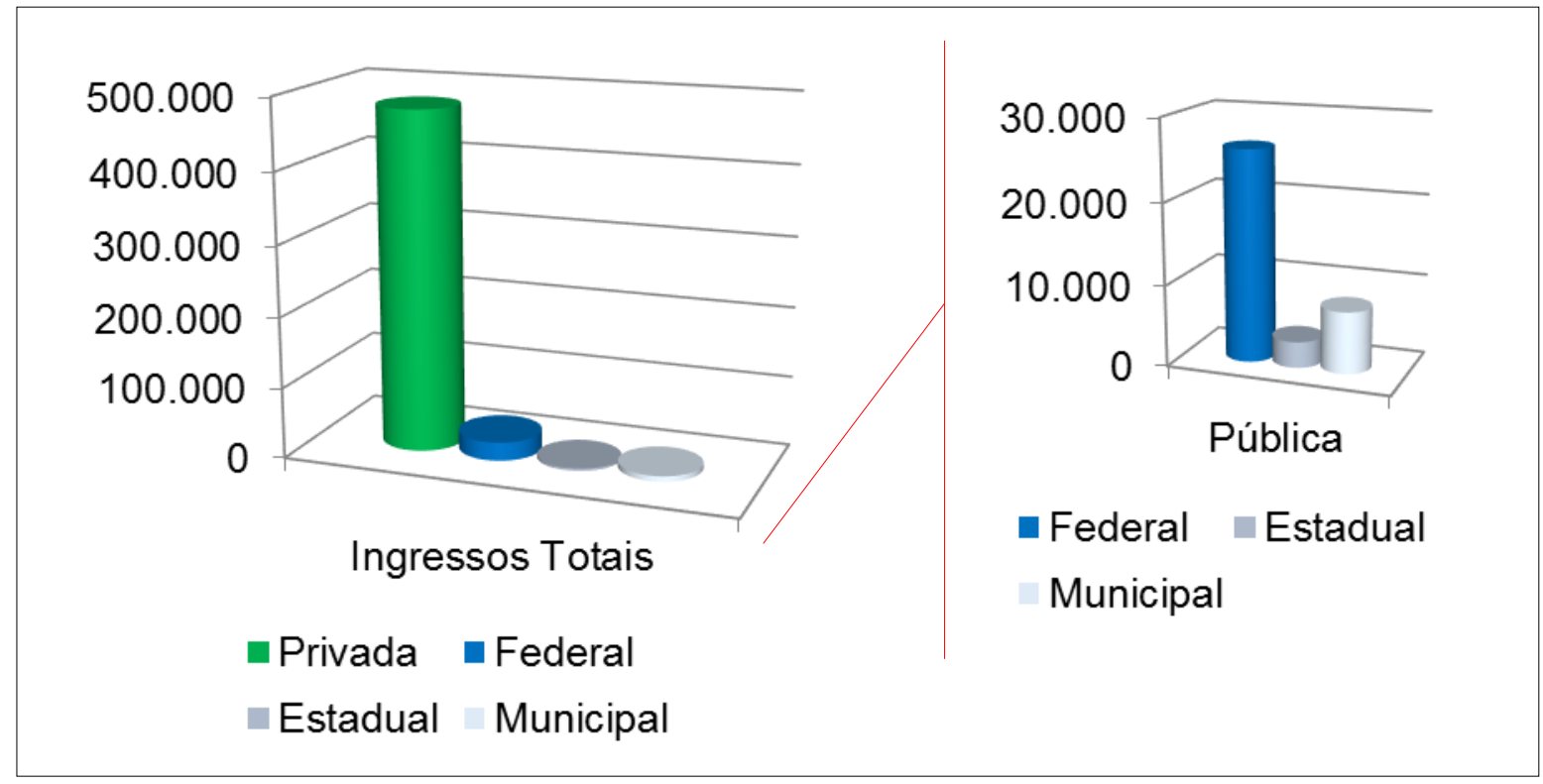

Fonte: Fonte: MEC/Inep

Gráfico 6 - Matrículas nos Cursos de Graduação a Distância, por Categoria Administrativa das IES - 2013

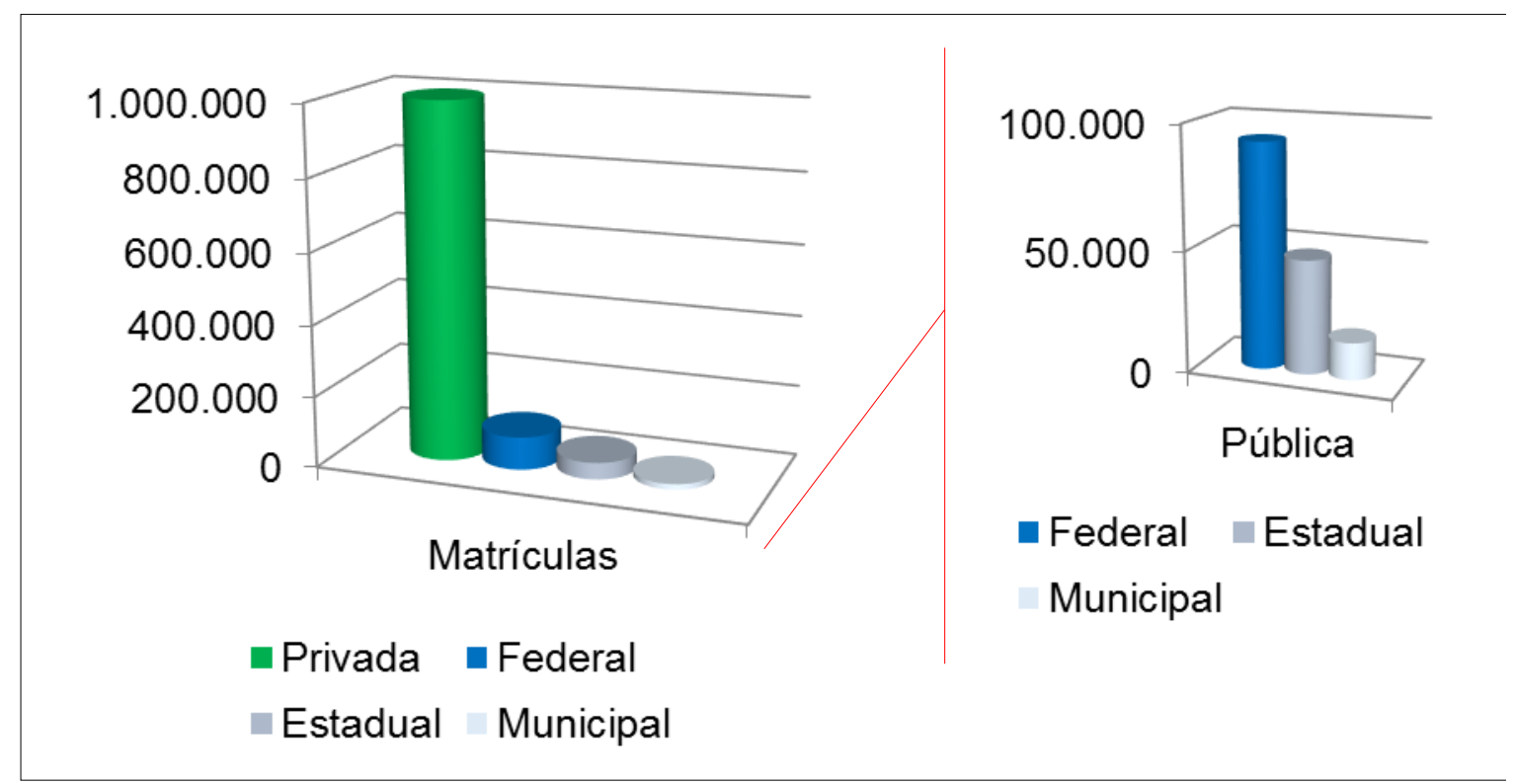

Fonte: Fonte: MEC/Inep

Gráfico 7 - Concluintes nos Cursos de Graduação a Distância, por Categoria Administrativa das IES - 2013 


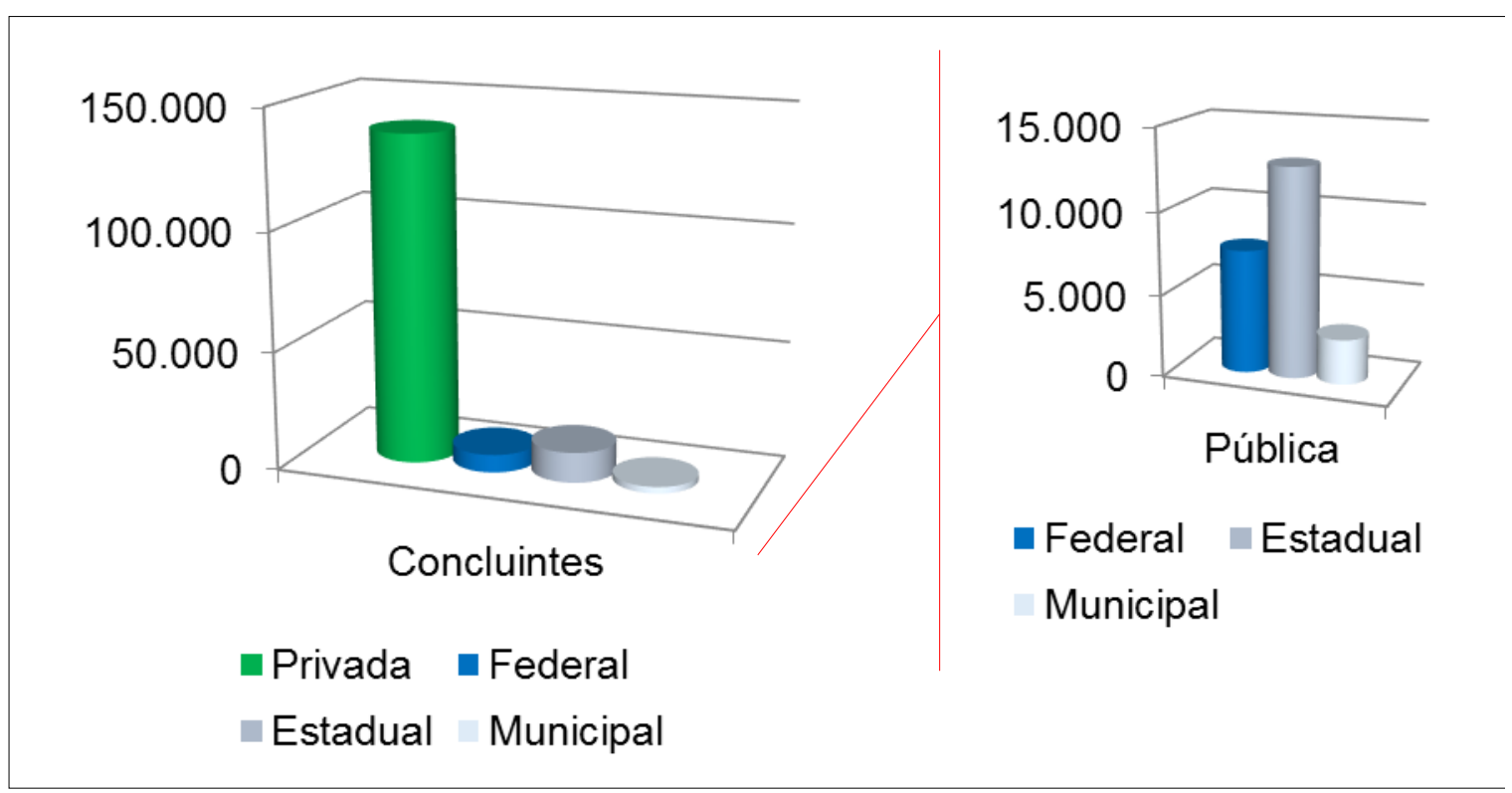

Fonte: Fonte: MEC/Inep

Representando os dados referentes aos programas e cursos de graduação a distância para formação de professores, temos a Tabela 5. Dentre os 1258 cursos de graduação a distância oferecidos em todo país, 589 (46,82\%) estão destinados a áreas da educação; esses estão distribuídos, segundo categoria administrativa, em sua maioria em instituições públicas, onde 364 (federal 64,83\%; estadual 30,77\%; municipal 4,40\%) pertencem a instituições públicas contra 225 em privadas. Apesar da mudança de cenário privatista nos cursos da área de educação, na avaliação total dos números de cursos oferecidos de graduação a distância, o predomínio de instituições privadas permanece inalterado, chegado a $59,78 \%$ representados por instituições privadas contra 40,22\% nas públicas.

Pedagogia é o programa com maior numero de cursos de graduação a distância, 115 cursos no total para educação, sendo 56 em instituições públicas e 59 privadas; o programa de formação básica para séries finais do ensino fundamental possui apenas um curso disponível; porém, dentre todas as áreas representadas na categoria educação, a mais representativa é para formação de professor de matérias específicas, configurando 393 cursos dos 589 disponíveis. 
Tabela 5 - Número de Cursos de Graduação a Distância, por Categoria Administrativa das IES, segundo as Áreas Gerais, Áreas Detalhadas e Programas e/ou Cursos - Brasil - 2013

\begin{tabular}{|c|c|c|c|c|c|}
\hline \multirow{4}{*}{$\begin{array}{c}\text { Áreas Gerais, Áreas Detalhadas e Programas } \\
\text { e/ou Cursos }\end{array}$} & \multicolumn{5}{|c|}{$\begin{array}{l}\text { Número de Cursos de Graduação a } \\
\text { Distância }\end{array}$} \\
\hline & \multicolumn{5}{|c|}{ Total } \\
\hline & \multicolumn{4}{|c|}{ Pública } & \multirow[b]{2}{*}{ Privada } \\
\hline & Total & Federal & Estadual & Municipal & \\
\hline Total & 1.258 & 313 & 132 & 61 & 752 \\
\hline Educação & 589 & 236 & 112 & 16 & 225 \\
\hline Ciências da educação & 116 & 33 & 20 & 3 & 60 \\
\hline Pedagogia & 115 & 33 & 20 & 3 & 59 \\
\hline Formação de professor da educação básica & 1 & 1 & - & - & - \\
\hline $\begin{array}{l}\text { Formação de professor das séries finais do } \\
\text { ensino fundamental }\end{array}$ & 1 & 1 & - & - & - \\
\hline $\begin{array}{l}\text { Formação de professor de disciplinas } \\
\text { profissionais }\end{array}$ & 79 & 36 & 21 & 4 & 18 \\
\hline $\begin{array}{l}\text { Formação de professor de artes (educação } \\
\text { artística) }\end{array}$ & 3 & - & 1 & - & 2 \\
\hline Formação de professor de educação física & 15 & 9 & 2 & 1 & 3 \\
\hline $\begin{array}{l}\text { Licenciatura para a educação profissional e } \\
\text { tecnológica }\end{array}$ & 6 & 1 & - & 1 & 4 \\
\hline $\begin{array}{l}\text { Formação de professor de matérias } \\
\text { específicas }\end{array}$ & 393 & 166 & 71 & 9 & 147 \\
\hline Formação de professor de biologia & 53 & 24 & 16 & 1 & 12 \\
\hline Formação de professor de ciências & 7 & 5 & 1 & - & 1 \\
\hline Formação de professor de filosofia & 13 & 3 & 1 & 1 & 8 \\
\hline Formação de professor de física & 26 & 18 & 3 & - & 5 \\
\hline Formação de professor de geografia & 33 & 9 & 5 & 1 & 18 \\
\hline Formação de professor de história & 33 & 4 & 8 & 1 & 20 \\
\hline $\begin{array}{l}\text { Formação de professor de língua/literatura } \\
\text { estrangeira moderna }\end{array}$ & 34 & 14 & 11 & - & 9 \\
\hline $\begin{array}{l}\text { Formação de professor de língua/literatura } \\
\text { vernácula (português) }\end{array}$ & 53 & 20 & 10 & - & 23 \\
\hline $\begin{array}{l}\text { Formação de professor de língua/literatura } \\
\text { vernácula e língua estrangeira moderna }\end{array}$ & 28 & 6 & 2 & 1 & 19 \\
\hline Formação de professor de matemática & 65 & 39 & 6 & 2 & 18 \\
\hline Formação de professor de química & 31 & 23 & 3 & 1 & 4 \\
\hline Formação de professor de sociologia & 16 & 1 & 4 & 1 & 10 \\
\hline
\end{tabular}

Fonte: Fonte: MEC/Inep 


\section{Reinventando o dialogo}


Conforme vimos refletindo, tem havido em especial a partir da última década do século passado, ênfase na elaboração e implantação de políticas públicas para solidificar um sistema nacional de educação e ampliar o acesso e a escolaridade de amplos setores da população brasileira, ainda que essas políticas, fortemente marcadas pela ideologia neoliberal, favoreçam a continuidade de uma abordagem instrumental da educação.

A extensão das oportunidades de acesso aos diversos níveis de ensino tem se consolidado e tende a se manter, pelo menos em termos quantitativos.

No entanto, a prosseguirmos na inércia que pressupõe a pedagogia instrumental voltada para atender as demandas e os caprichos do mercado e na dependência dos modelos educacionais das economias centrais, os cidadãos "mínimos" ${ }^{5}$ que seguiremos formando continuarão a não estabelecer nenhuma relação criativa e transformadora entre suas vidas e a vida do país.

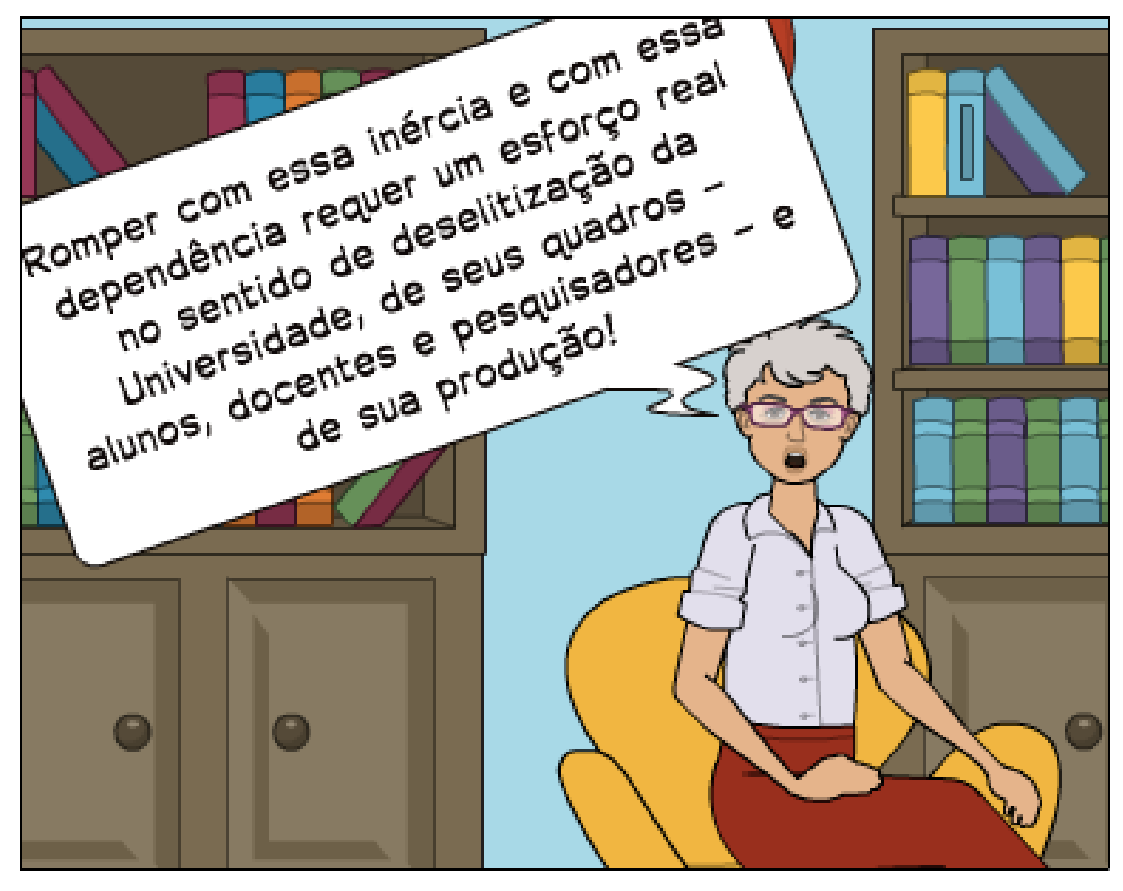

"O ideário pedagógico das reformas educativas das ditaduras militares na América Latina, sob a noção de capital humano e, atualmente, sob a ditadura do mercado, com as noções de sociedade do conhecimento, pedagogia das competências, e empregabilidade, necessitam ser superadas. $O$ escopo destas concepções é da formação de um "cidadão

\footnotetext{
${ }^{5}$ Conforme Frigotto (2001)
} 
produtivo alienado" cidadão mínimo que acabe introjetando a culpabilização de sua pouca escolaridade e de sua situação de desempregado ou subempregado." (Frigotto e Ciavatta, 2002),

Têm que partir da Universidade - a filha dileta de nosso sistema de educação elitista e excludente, assim forjado no intuito de preservar as desigualdades que asseguram os privilégios do 'andar de cima' 6 -, ações efetivas para a criação de um ambiente educacional público colaborativo e interativo, em todos os seus níveis.

As tecnologias de comunicação - do livro ao computador - explorados, até então, nos contextos formais de aprendizagem, apenas em sua instrumentalidade, têm que se configurar em portais para novas dimensões da formação escolar, profissional e humana.

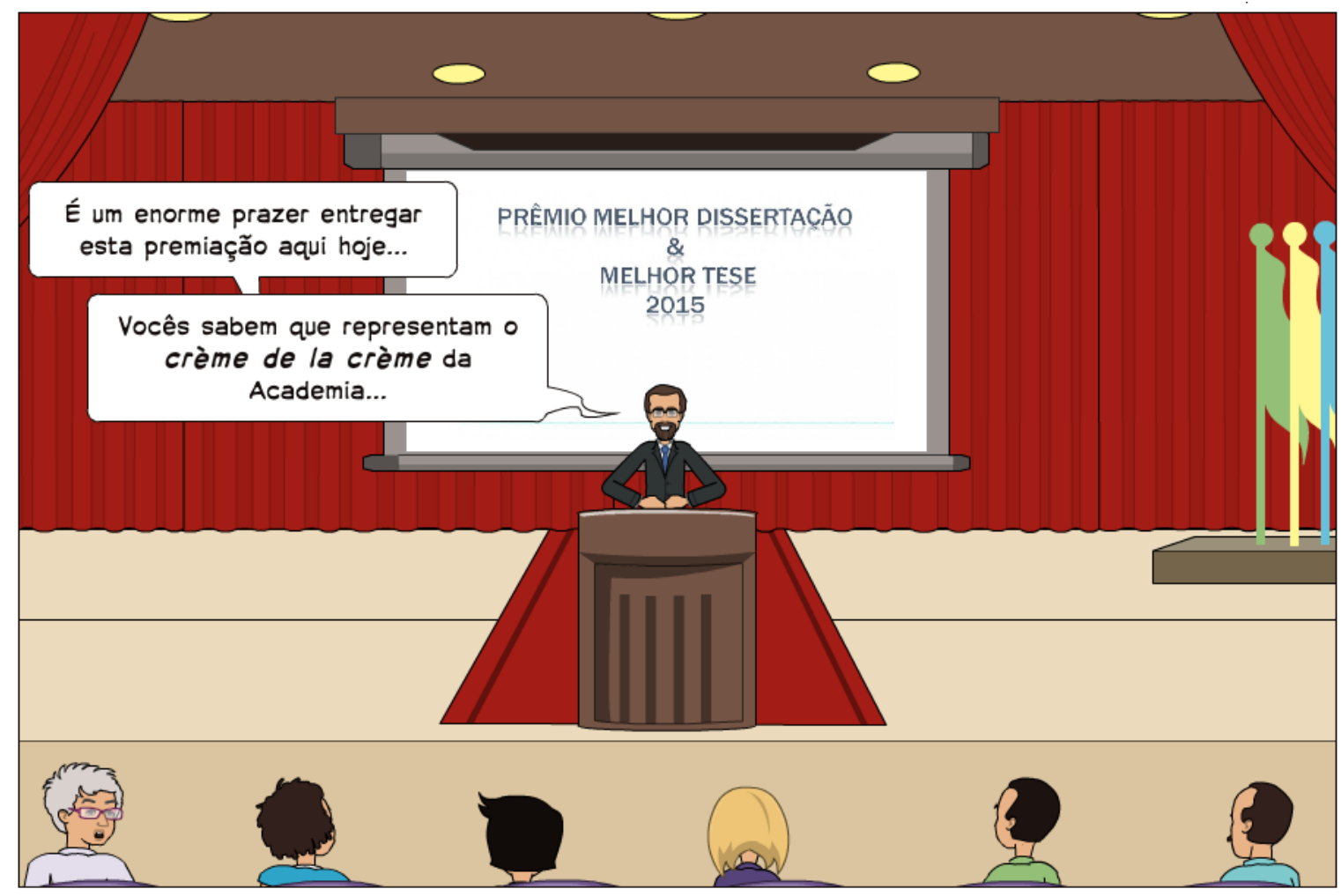

"A grande mutação tecnológica é dada com a emergência das técnicas da informação, as quais - ao contrário da técnicas

\footnotetext{
${ }^{6}$ Conforme expressão consagrada pelo poeta Patativa do Assaré
} 
das máquinas - são constitucionalmente divisíveis, flexíveis e dóceis, adaptáveis a todos os meios e culturas, ainda que seu uso perverso atual seja subordinado aos interesses dos grandes capitais. Mas, quando sua utilização for democratizada, essas técnicas doces estarão ao serviço do homem." (SANTOS, 2002)

Assim como nossos alunos não devem ler livros apenas para acumular um pequeno repertório de cultura erudita ou para responder às questões de vestibular, também não devem aprender a "usar" o computador para ampliar sua "empregabilidade". O de que eles precisam, assim como seus professores, é que todas as mídias sejam incorporadas em sua formação como possiblidades de construção de conhecimento, construção de narrativas próprias, ampliação de vozes.

"Si logramos compreender que el problema no es tecnológico, sino de comunicación, daremos passos seguros para integrar las tecnologias digitales a los processos de aprendizaje. [...] La educación no se define como un fondo de verdades cerrado, archivable y transmisible, es más bien el campo fértil que acerca a lo todavia desconocido. Es por ello que las funciones de investigación, desarrollo e innovación, y de comunicación, no son ajenas a la educación, y resultan prioritárias. El acento debiera estar em el dissenso, em las diferencias y em la búsqueda del descubrimiento y el hallazgo." (QUIROZ VELASCO, 2012)

Em trabalho apresentado no XXIV INTERCOM, Cury (2000) já alertava para a necessidade de mudança de perspectiva da Universidade e dos estudos de Pósgraduação sobre suas relações com as novas demandas socioeducativas que as tecnologias digitais de comunicação estavam configurando.

"[trata-se de] redefinir essa nova responsabilidade, assim como a reestruturação de uma comunidade de pensamento, para a qual a fronteira entre pesquisa fundamental e pesquisa finalizada não estivesse mais assegurada, pelo menos, não nas 
mesmas condições em que se encontra ou, se encontrava antes. Uma comunidade de pensamento, no sentido mais amplo possível, não somente de pesquisa, de ciência ou de filosofia.

Essas novas responsabilidades que recaem sobre a Universidade não podem ser apenas acadêmicas, ou intrauniversitárias, controladas pelas normas profundas e pelos programas que aí são analisados. Não importa apenas formular questões, mas preparar-se para transformar a cena pedagógica, colocando-a em relação com as instituições em geral, com seu interior, mas também com seu exterior. Nesse sentido, cabe também redefinir o conceito de comunidade e o de instituição." (Cury, 2000)

E a autora compartilha com Derrida uma reflexão sobre o estigma da 'pesquisa aplicada', da 'finalidade', que tanto assombra a Universidade e seus quadros mais ortodoxos:

"Cuidado com o que abre a Universidade para o exterior e para o sem fundo, mas cuidado também com o que, fechandoa em si mesma, não criaria senão um fantasma, sem existência concreta e útil, completamente a serviço de quaisquer interesses." Diz, e ao mesmo tempo, questiona: "cuidado com as finalidades; mas o que seria uma Universidade sem finalidades?" (DERRIDA apud CURY, 2000)

Dentro dos limites deste trabalho, com base na constante observação dos espaços escolares formais de todos os níveis e na experiência profissional docente também em todos os níveis, concluímos nossas reflexões com algumas propostas de ação comunicativo-pedagógicas para as FATECs, instituições paulistas de ensino superior tecnológico. 
A Universidade tem que se aproximar do ensino básico, meter a mão na massa, reverter 0 afastamento entre 0 mundo acadêmico e mundo da escola e emanciparse a si mesma, na cooperação ativa para a emancipação da educação básica publica.

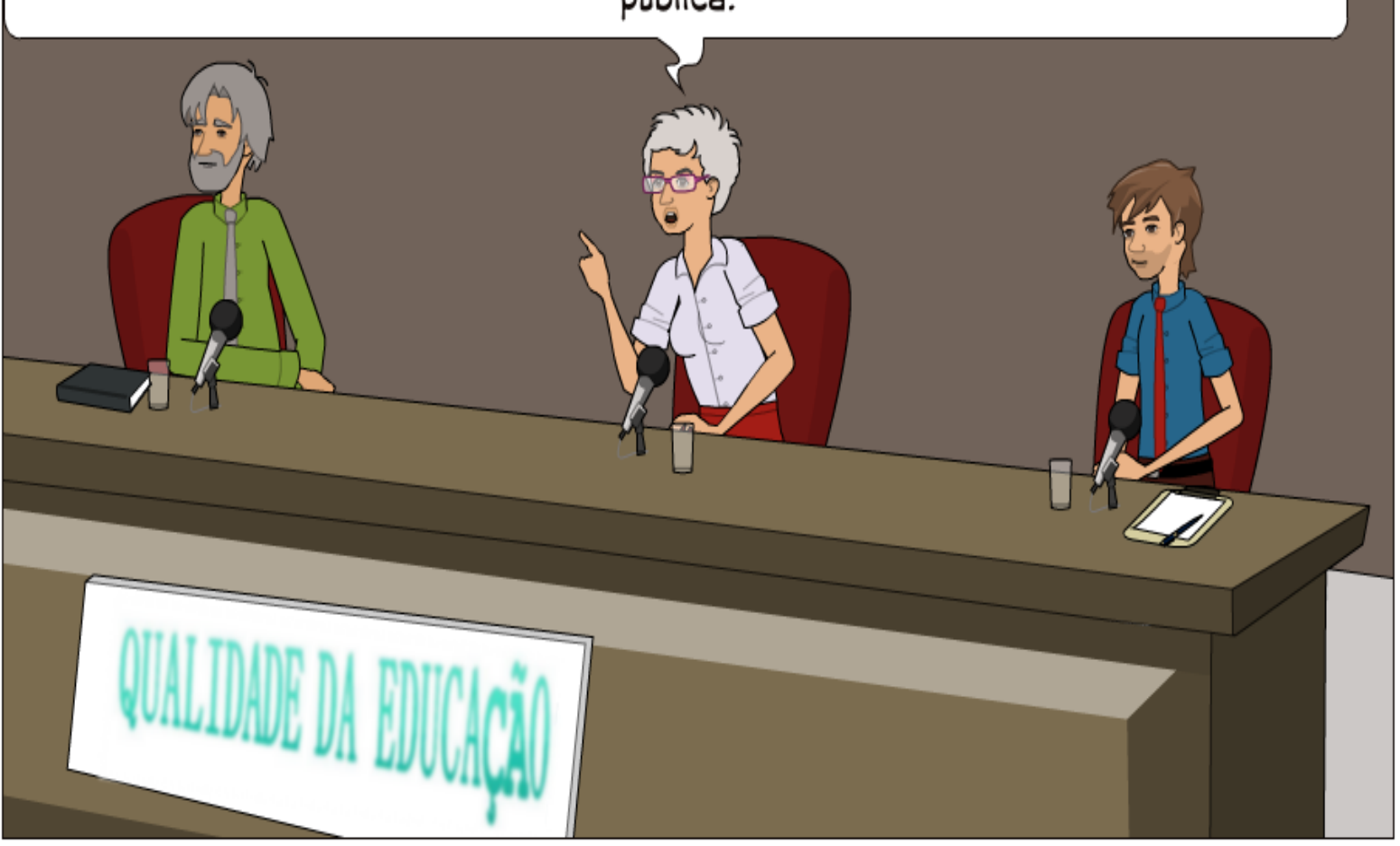


5.1. Aproximação entre ensino superior e ensino básico: ênfase no ensino por pesquisa/projeto

\section{Fórum Conexões Politécnicas}

Espaço aberto e multilateral de estudos colaborativos em aprendizagem através da pesquisa

Trata-se de uma proposta de conexão entre a graduação tecnológica, a pós graduação tecnológica e o ensino básico médio e técnico, por meio da estruturação de espaços físicos e virtuais de debates públicos, abertos e gratuitos, em que se desenvolvem discussões, estudos e trocas de experiências e resultados de projetos de aprendizagem através da pesquisa.

Essa proposta de ação pressupõe que a CESU - Coordenação de Ensino Superior do Centro Paula Souza - elabore e incentive uma programação de atividades que abrangerá fóruns virtuais de periodicidade bimensal, em que ocorrerão discussões preparatórias de temas, elaboração de propostas, projetos e ações que, em um grande fórum presencial anual, serão avaliados e finalizados em forma de construção coletiva para publicações impressas, vídeo documentários de curta metragem, mostras e exposições circulantes a serem apresentadas e reproblematizadas nas ETECs e FATECs de todo o Estado.

As Conexões serão propostas e mediadas pelos núcleos de pesquisa do ensino médio, técnico, graduação e pós graduação do Centro Paulo Souza, responsáveis por uma gestão democrática e participativa do Fórum.

Com esta proposta visa-se atingir concomitantemente três objetivos que consideramos estratégicos para promover transformações importantes no contexto da educação profissional:

a) Recuperar a potência do fórum na instauração de ambientes comunicativos democráticos e participativos, presenciais e virtuais

b) Reinventar a prática do debate público, formativo e tolerante, como instância de criação, compartilhamento e divulgação de conhecimento e inovação 
c) Promover ampla discussão sobre a práxis emancipadora da pesquisa colaborativa nos processos dialógicos e retro alimentadores de ensinoaprendizagem 
5.2. Aproximação entre ensino superior e ensino básico: ênfase na formação continuada de professores

\section{Fórum Extensões Plurais}

Ambiente virtual aberto e gratuito de formação continuada de professores (com ênfase em comunicação e tecnologias)

Propõe-se que a tão necessária formação continuada dos professores de educação técnica e tecnológica ocorra por meio de uma programação ampla e regular de fóruns temáticos, organizados e mediados pela equipe pedagógica da CESU - Coordenação de Ensino Superior do Centro Paula Souza - em conjunto com pesquisadores da Pós Graduação e da Licenciatura da instituição, com vistas a sistematizar conhecimento já construído sobre determinados temas que atravessam a vida contemporânea e com os quais os professores devem estabelecer diálogo crítico, independentemente das disciplinas que ministram, dada a importância com que a contextualização opera no processo de construção de significados. Os temas devem ser tratados não só na especificidade de sua área do saber, mas em suas complexas ligações transdisciplinares, o que vale dizer, por exemplo, que num Fórum Extensões Plurais sobre Economia, a economia deve compor um tema em suas relações com a ciência, a tecnologia, a sociedade e a educação.

Mais uma vez, objetiva-se com essa proposta que, além da efetiva formação continuada de professores da educação técnica e tecnológica, reinvente-se a prática do debate público, construtivo e tolerante, sobre temas absolutamente fundamentais para a vida das pessoas, da sociedade e do país e sem cujo domínio não se dá uma leitura adequada - ampla, complexa e pluridimensional - dos problemas do mundo. 
5.3. Proposta de ação comunicativo-pedagógica para a construção de alternativa e intervenção transformadoras da educação tecnológica

\section{Fórum Diálogos sobre Educação Tecnológica}

A educação tecnológica é educação de nível superior equivalente a qualquer outro curso de graduação, mas sobre ela recai ainda o forte estigma de educação de segunda mão, em consequência da dualidade estrutural que caracteriza nosso sistema.

Mesmo entre os que estão envolvidos na educação tecnológica - alunos, docentes, gestores, funcionários - sobrevive a visão de uma educação instrumental, voltada mais para o adestramento profissional do que para a formação integral do educando.

Disso resulta muita distorção nos projetos pedagógicos de cursos e disciplinas, nas atividades de pesquisa e extensão e, consequentemente, no perfil de formação do egresso da educação tecnológica que acaba por não atender às expectativas nem de 'gregos' nem de 'troianos' - a educação propedêutica os considera "técnicos e estreitos" demais para a continuidade dos estudos em nível de pós graduação; e o mercado os quer mais flexíveis e polivalentes.

A proposta do Fórum Diálogos sobre Educação Tecnológica objetiva uma ação comunicativo-pedagógica para a construção de alternativas e intervenções transformadoras, centrada no diálogo, na informação historicamente contextualizada, no estudo das origens das diferentes concepções, na discussão sobre quais concepções orientam a educação tecnológica nas FATECs e sobre a reorientação necessária para o enfrentamento da dispersão, da evasão, dos baixos resultados e da falta de sintonia com os anseios da sociedade.

A atividade proposta, que seria implantada e coordenada pela equipe pedagógica da CESU - Coordenação de Ensino Superior do Centro Paula Souza - consiste de 8 (oito) Fóruns a serem realizados em periodicidade mensal entre março e novembro de 2015. O primeiro e o último Fóruns ocorrerão em encontros presenciais, abertos, públicos e gratuitos, e os demais se darão por participação on-line em plataforma a ser definida. 
Novamente aqui, tem-se a preocupação de atender a objetivos estratégicos, que consistem em recuperar a potência do fórum na instauração de ambientes comunicativos democráticos e participativos, presenciais e virtuais; reinventar a prática do debate público, formativo e tolerante, como instância de criação, compartilhamento e divulgação de conhecimento e inovação; e promover ampla discussão sobre a potencialidade emancipadora da educação tecnológica - para o educando e para o país.

(Entre os anexos a este trabalho encontra-se a minuta do Primeiro Caderno para os Diálogos sobre educação tecnológica - Primeiro Caderno) 

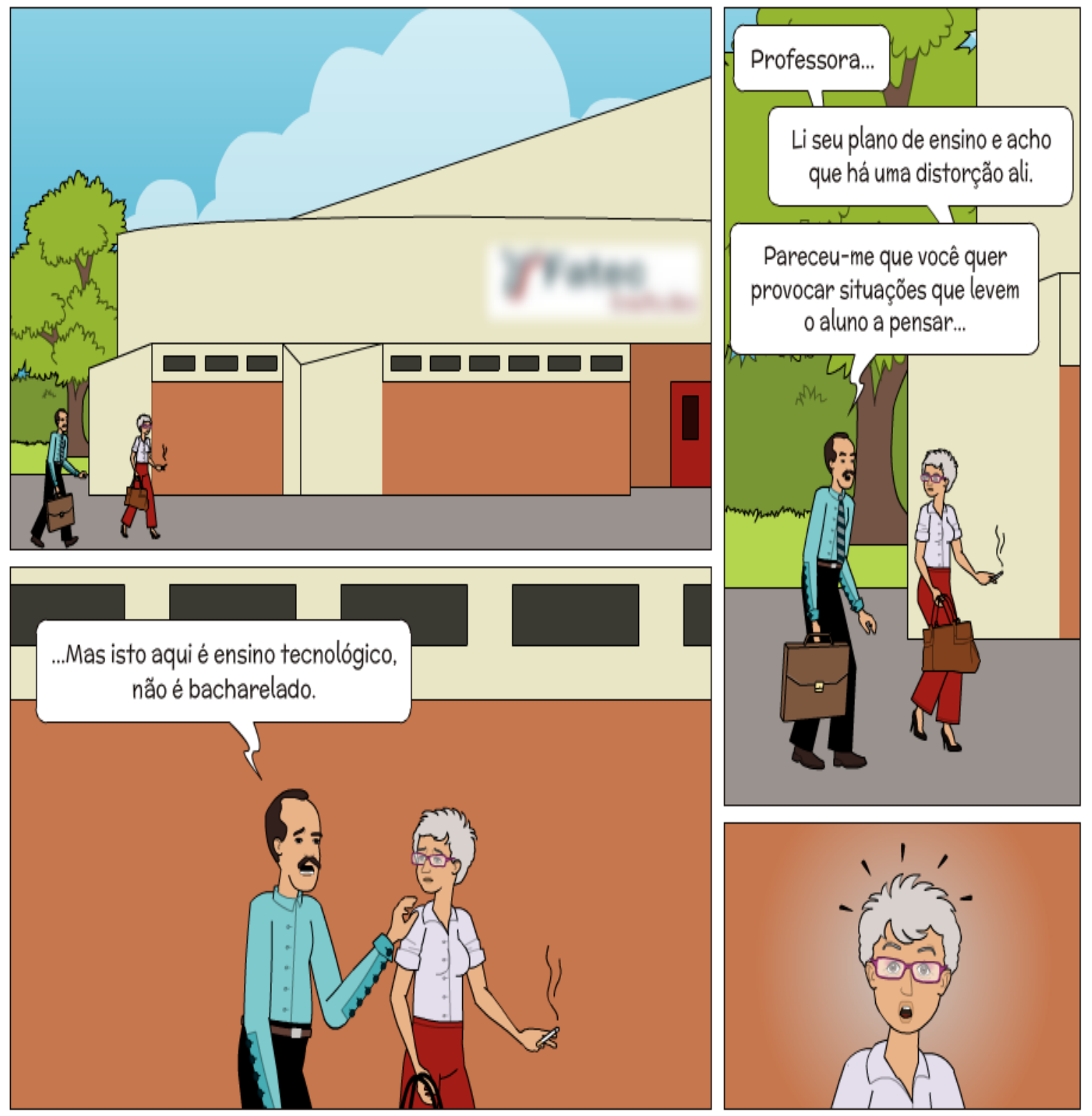
"Gente livre significa gente capaz de saber ler a publicidade e entender para que serve, e não gente que deixa massagear o próprio cérebro; gente que seja capaz de distanciar-se da arte que está na moda, dos livros que estão na moda, gente que pense com sua cabeça e não com as ideias que circulam ao seu redor." (MARTIN-BARBERO, 2000) 
6 Considerações Finais 
"A globalização atual e as formas brutais que adotou para impor mudanças levam à urgente necessidade de rever o que fazer com as coisas, as ideias e também com as palavras." (SANTOS, 2002)

6.1. Um mundo coberto de papers... mas, ... 'vocês não estão entendo nada!'

De que nos vale uma universidade e quadros acadêmicos exímios 'fazedores de papers', citados e citadores em sofisticadas e caras publicações científicas, ativos participantes e organizadores de milionários congressos nacionais e internacionais, se a educação básica em nosso país continua isolada e precária, se o ensino profissional, técnico e tecnológico continua a ser estigmatizado como educação de segunda classe?

Essa disparidade só evidencia que não são apenas os estudantes do ensino básico brasileiro que não conseguem ler o mundo, que não estão aptos a entender o passado e o presente de seu país e a intervir na construção de um futuro, de um projeto para uma sociedade mais justa, democrática e sustentável.

Esse mundo acadêmico coberto de papers sem qualquer vínculo com nossas demandas de profunda transformação cultural e educacional forma, por

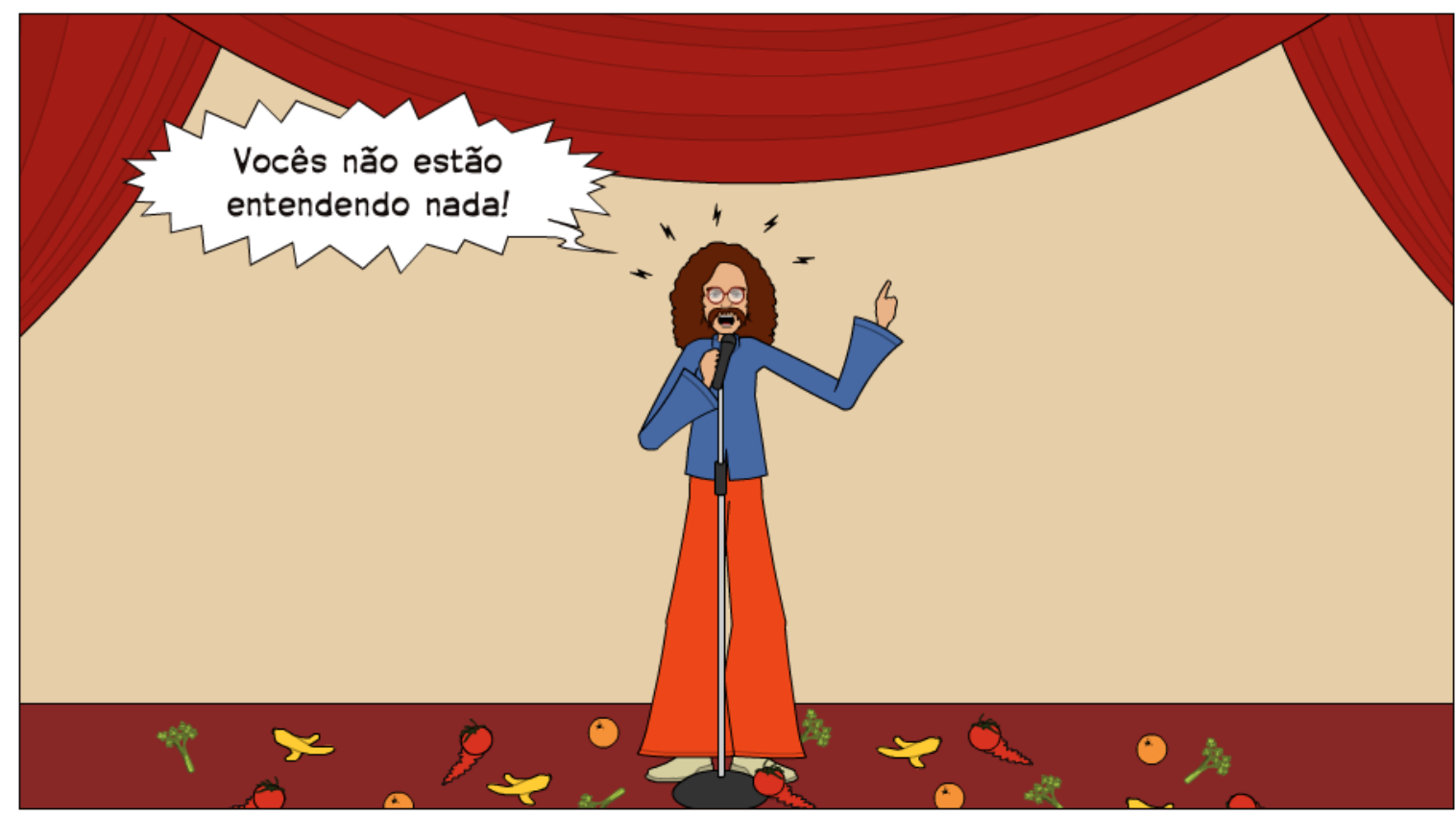


exemplo, médicos prepotentes que obstaculizam as políticas de saúde pública e inviabilizam a interiorização de atendimento médico aos grotões do país; jornalistas alienados que pactuam sem o menor problema de consciência com os interesses dos donos dos meios de comunicação; especialistas em semiótica que identificam propaganda de esquerda nas ciclo faixas vermelhas que buscam tornar os ambientes urbanos mais sustentáveis e mais humanos; professores pretenciosos que lamentam a massificação do ensino e o "risco" que as mídias todas - história em quadrinhos, pixo, grafite, tevê, vídeo, computador, celular etc - representam para a cultura escolar.

É de um grande artista brasileiro, que a propósito não tem título de doutor, as palavras que parafraseamos, porque melhor responderiam a essa Universidade tão vaidosa de seus índices em um país que amarga baixíssimos resultados na formação básica de suas crianças, jovens e trabalhadores:

"Vocês não estão entendendo nada!" (grifo nosso) (VELOSO, Caetano. Discurso improvisado no FIC (Festival Internacional da Canção), 1968) 

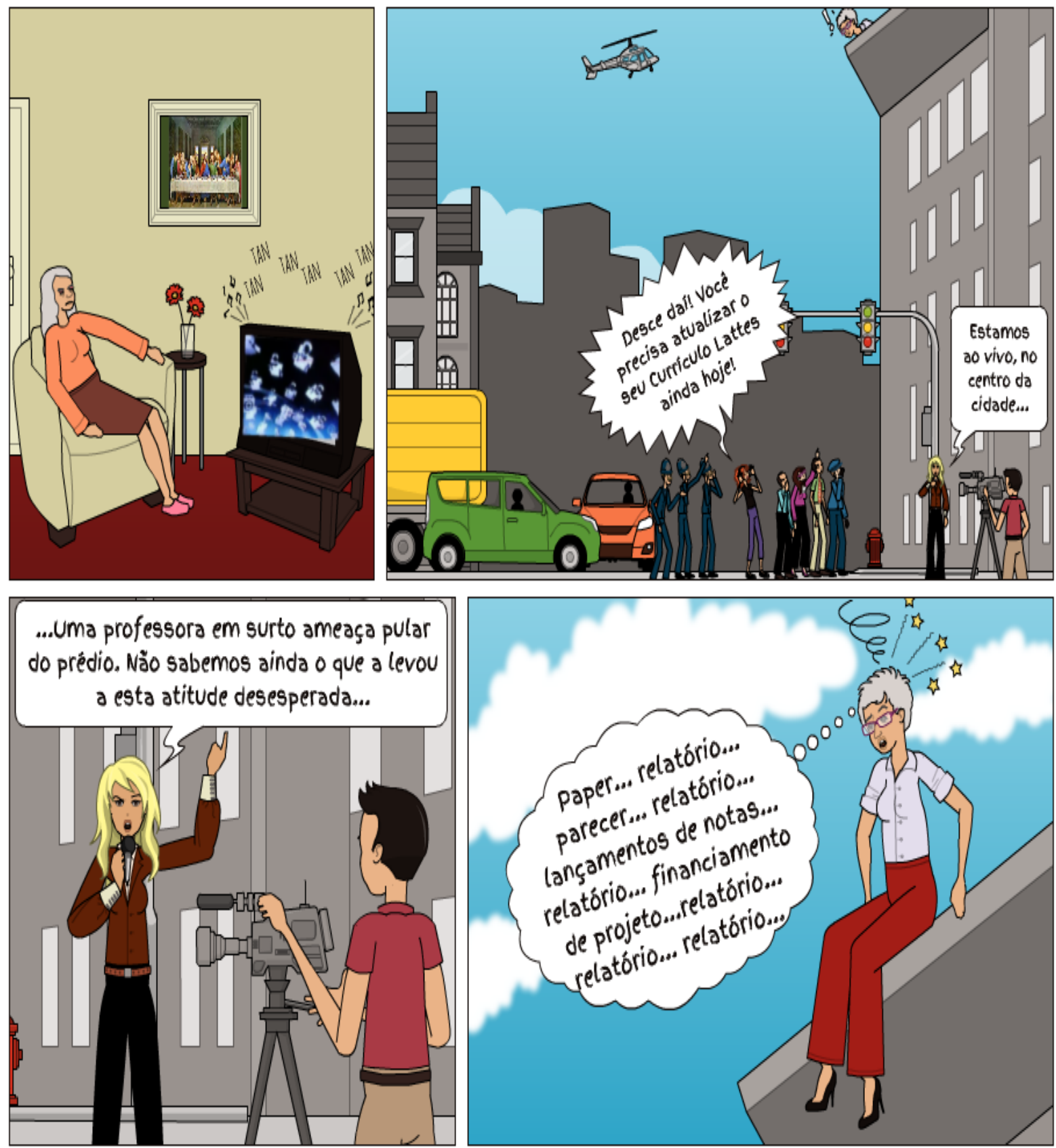
6.2. O direito democrático aos caminhos da pesquisa e à participação no bolo do conhecimento acumulado

Pesquisa é processo que deve aparecer em todo trajeto educativo. A Universidade detém o know-how da pesquisa. Os demais trajetos educativos - 0 ensino básico e o ensino profissional - precisam do know-how da Universidade e de sua mediação para desenvolver sua própria prática de pesquisa. As tecnologias de comunicação permitem a troca de conhecimento e experiência a baixo custo, em tempo integral, desde que os fluxos sejam configurados em redes dinâmicas e abertas, como são as redes sociais.

A forma de comunicação e de linguagem nessas redes de estudo e pesquisa e formação tem que distanciar-se dos modelos herméticos e dos jargões acadêmicos. Democratizar o conhecimento construído pela Universidade pressupõe democratizar as relações de poder dentro dela, e entre ela e a sociedade, inclusive as relações de poder que se configuram pela linguagem e pelas formas comunicacionais.

"Num país democrático, ou que se queira democrático, a universidade precisa romper com o elitismo que a concebeu e engajar-se num projeto nacional que promova o acesso das populações hoje excluídas e transforme as universidades brasileiras em universidades do povo, para o povo e pelo povo. (RISTOFF, 2003)

A Universidade deve estabelecer um canal aberto de comunicação com os profissionais da docência em todos os níveis para discussão e estudos colaborativos multidisciplinares. A formação continuada não deve ser compulsória e proposta de cima para baixo, por meio de deliberações e portarias dos ministérios e secretarias de educação. Trata-se da tal comunidade de pensamento, de que nos fala Cury (2001) e que ações efetivas da academia têm que inaugurar e colocar à disposição da sociedade urgentemente. 
Nesse processo de abertura e generosidade - aproximando-se dos outros níveis de ensino não para torná-los em objetos de suas pesquisas, mas para pesquisar com eles e para eles -, a Universidade reconquistará sem dúvida sua legitimidade social (SOUSA SANTOS, 2005), porque os problemas a serem debatidos e pesquisados por intensa demanda da sociedade levarão a academia a uma expansão de sua capacidade de leitura do mundo e do país e de intervenção nos contextos que exigem transformação. 
7 Referências 
ADORNO, Theodor W. Educação e Emancipação. São Paulo: Paz e Terra, 1995.

AZEVEDO, Janete M. Lins de. A Educação como Política Pública. 2. ed. Campinas, SP: Autores Associados, 1997.

AZEVEDO, M.L.N.; CATANI, A.M. Políticas Públicas para a Educação Superior no Brasil: de FHC a Lula. In: AZEVEDO, M.L.N. (Org). Política Educacional Brasileira. Maringá/PR: EDUEM, 2005.

BENJAMIN, Walter. Magia e técnica, arte e política. São Paulo: Ed. Brasiliense, 1993.

BOURDIEU, P. O campo científico. In: (Org. R. Ortiz). Pierre Bourdieu: Sociologia. São Paulo: Ática, 1983.

; PASSERON, Jean-Claude. A Reprodução: elementos para uma teoria do sistema de ensino. 2a ed. Rio de Janeiro: Francisco Alves, 1982.

. Les structures sociales de l'économie. Paris: Seuil, 2000.

. Os usos sociais da ciência: por uma sociologia clínica do campo científico. São Paulo: EDUNESP, 2004.

. Homo academicus. Paris: Minuit, 1984.

BRANDÃO, Carlos da Fonseca. LDB passo a passo. São Paulo: Avercamp, 2010. BRASIL. Lei no 9.393/96, de 20 de dezembro de 1996. Estabelece as diretrizes e bases da educação nacional. Brasília/DF, Diário Oficial da União, 1996.

. Presidência da República. Lei n.11.096. Institui o Programa Universidade Para Todos

. Decreto Presidencial n. 6.096, de 24 de abril de 2007 que Institui as Diretrizes do Programa de Apoio a Planos de Reestruturação e Expansão das Universidades Federais - REUNI.

CASTELLS, Manuel. A sociedade em rede. São Paulo: Paz e Terra. 2005.

CATANI, Afrânio Mendes, OLIVEIRA, João Ferreira. Educação Superior no Brasil: reestruturação e metamorfose das universidades públicas. Petrópolis/RJ: Vozes, 2002.

. Políticas e gestão da educação superior. São Paulo: Xama, 2003.

. Acesso e permanência no ensino superior: capacidades, competição e exclusão social. In: SEVERINO, Antônio J.; FAZENDA, Ivani C. A. (Orgs). Políticas educacionais: o ensino nacional em questão. Campinas/SP: Papirus, 2003. 
\& HEY, Ana Paula, 2007. A Educação Superior no Brasil e as tendências de ampliação do acesso. In: Atos de Pesquisa em Educação. PPGE/ME FURB, v. 2, no 3, p. 414-429, set./dez. 2007.

; GILIOLI, R. O PROUNI na encruzilhada: entre a cidadania e a privatização. Linhas Críticas. Brasília, UnB,v. 11, n. 20, p. 55-68, jan.jjun. 2005.

; HEY, A.P.; GILIOLI, R. PROUNI: democratização do acesso às Instituições de Ensino Superior. Educar em Revista. Curitiba, UFPR, n. 28, p.125- 140, jul.- dez. 2006.

CURY, L. (Org.). Tecnologias digitais nas interfaces da comunicação/educação desafios e perspectivas. 1a.. ed. Curitiba: Editora CRV, 2012. v. 1. 212 p.

. Reflexões a respeito do papel da Universidade face à tecno-ciência In Anais do Congresso INTERCOM 2000 . In: INTERCOM 2000, 2000, Manaus, 2000. . O dilema da pesquisa. São Paulo: EDUSP, 2010.

DEMO, Pedro. A nova LDB - ranços e avanços. São Paulo: Papirus, 2011.

DOWBOR, Ladislau. Aspectos Econômicos da Educação. São Paulo: Editora Ática, 1986.

FERNANDES, Florestan. O desafio educacional. São Paulo: Cortez, 1989.

FREIRE, Paulo. Extensão ou comunicação? $7^{\text {a }}$ ed. Rio de Janeiro, Paz e Terra, 1983.

FRIGOTTO, Gaudêncio, CIAVATTA, Maria e RAMOS, Marise. Vocational Education and Development. In. UNESCO. International Handbook of Education for Changing World of Work. Bom, Germany, UNIVOC, 2009. p. 1 307-1319. - Coletânea organizada pelo Centro Internacional de Educação Técnica e Profissional, com o patrocínio da UNESCO. Berlim, 2005. . Educação e Trabalho: bases para debater a Educação Profissional Emancipadora. PERSPECTIVA, Florianópolis, v.19, n.1, p.71-87, jan./jun. 2001.

. Os circuitos da história e o balanço da educação no Brasil na primeira década do século XXI. Conferência de Abertura da 33a Reunião Anual da Associação Nacional de Pós-Graduação e Pesquisa em Educação (ANPEd). Caxambu-MG, 17 de outubro de 2010.

HARVEY, David. Condição pós-moderna. São Paulo: Edições Loyola, 2005. HEY, A. P. Esboço de uma sociologia do campo acadêmico: a educação superior no Brasil. São Carlos: EdUSCAR, 2008. 
LIMA, Lucínio C.; AZEVEDO, Mário Luiz Neves de; CATANI, Afrânio Mendes. O Processo de Bolonha, a Avaliação da Educação Superior e Algumas Considerações sobre a Universidade Nova. Avaliação, Campinas, v. 13, n.1, mar. 2008.

LOPES, Eliane Marta Teixeira; FARIA FILHO, Luciano Mendes e VEIGA, Cynthia Greive (orgs). 500 anos de educação no Brasil. Belo Horizonte: Autêntica, 2000. MARTIN-BARBERO, Jesús. A comunicação na educação. São Paulo: Contexto, 2014.

MARTIN-BARBERO, Jesús. Desafios culturais: da comunicação à educomunicação. Revista Comunicação \& Educação, no. 18, maio/ago 2000.

. Dos meios às mediações: comunicação, cultura e hegemonia. Rio de Janeiro: Editora UFRJ, 2003.

- La globalización en clave cultural: una mirada latino-americana. In Globalisme et Pluralisme - Colloque International. Montreal, 2002.

MOEHLECKE, Sabrina; CATANI, Afrânio Mendes. Reforma e Expansão do Acesso ao Ensino Superior: balanço e proposições. Série Documental. Textos para Discussão. MEC/INEP, 2006.

PACHECO, Eliezer; RISTOFF, Dilvo I. Educação superior: democratizando o acesso. Brasília: INEP, 2004.

QUIROZ VELASCO, Maria Teresa. Tecnologías Digitales: para la educación y la comunicación. In CURY, Lucilene (org.). Tecnologias digitais nas interfaces da comunicação/educação - desafios e perspectivas. Curitiba: CRV, 2012.

RISTOFF, Dilvo e BIANCHETTI, Lucídio. A pós graduação e suas interlocuções coma educação básica - (Des)encontros históricos e manutenção do apartheid socioeducacional. Avaliação, Campinas; Sorocaba, SP, v. 17, n. 3, p. 787-824, nov. 2012

- Políticas para a Educação Superior no Brasil: Deselitização e desprivatização. Revista Diálogo Educacional, Curitiba, v. 4, n.9, p.29-42, maio/ago. 2003.

A Educação Superior no Brasil: Panorama geral. In: Educação Superior Brasileira, 1991 - 2004. Brasília: INEP/MEC, 2005.

ROMANELLI, Otaíza de Oliveira. História da Educação no Brasil. Rio de Janeiro: Vozes, 1978. 
SANTOS, Milton. Por uma outra globalização: do pensamento único à consciência universal. Rio de Janeiro: Record, 2002.

SOARES, ISMAR DE OLIVEIRA. Gestão comunicativa e educação: caminhos da educomunicação. Comunicação \& Educação, São Paulo, (23): 16 a 25, jan/abr. 2002

SOUZA SANTOS, Boaventura de. A universidade no século XXI: para uma reforma democrática e emancipatória da universidade. São Paulo: Cortez, 2005.

. Da ideia de Universidade à Universidade de Ideias. Revista Crítica de Ciências Sociais, no. 27/28. Coimbra, 1989.

TRINDADE, Hélgio (org.). Universidade em ruínas na república dos professores. São Paulo: Vozes, 1999.

TROW, MARTIN A. Reflections on the transition from Elite to Mass to Universal Access: Forms and Phases of Higher Education in Modern Societies since WWII. UC Berkeley. 2005. 


\section{Anexos}




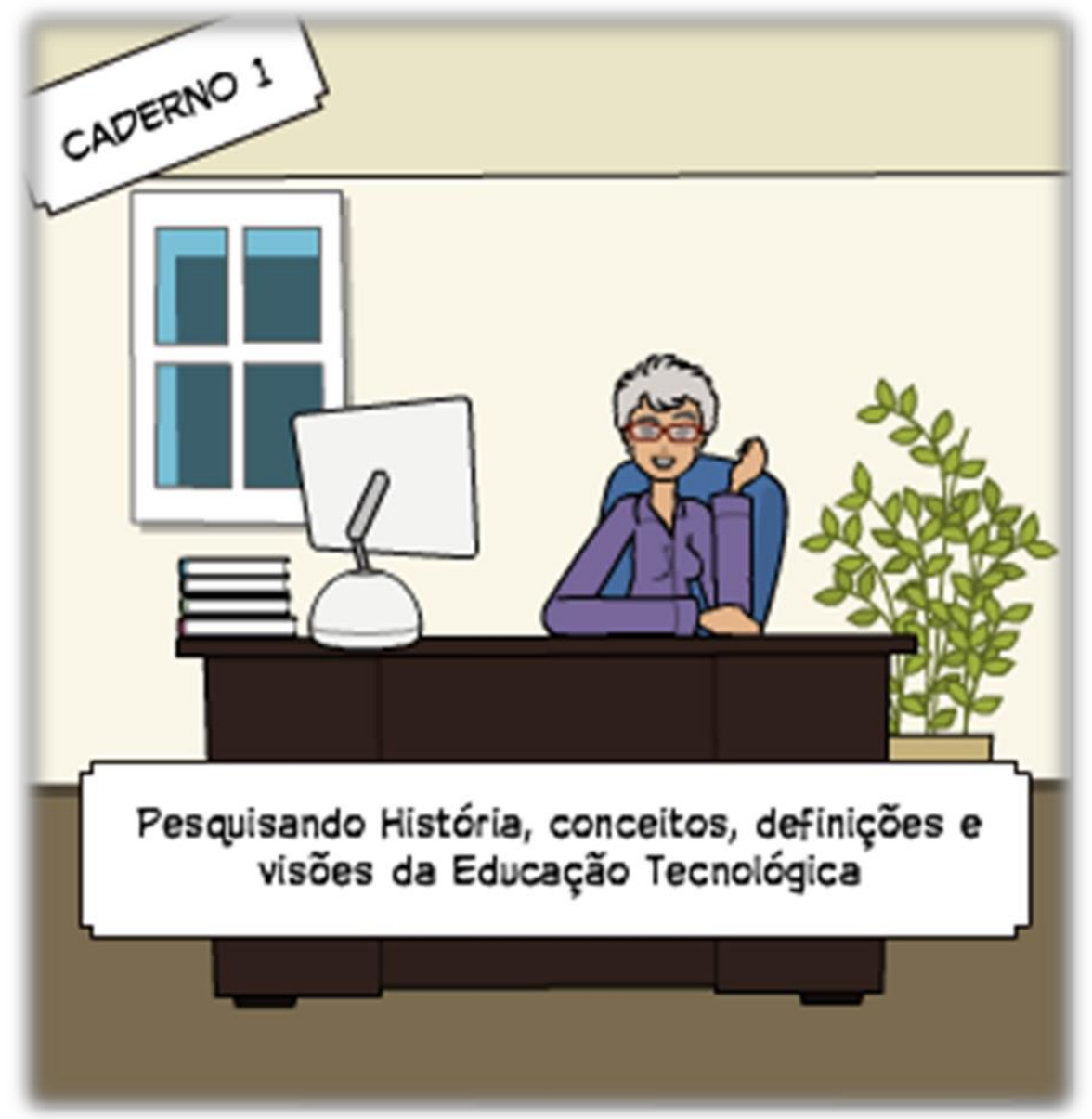

Diálogos sobre Educação Tecnológica

São Paulo - 2015 


\section{Diálogos sobre Educação Tecnológica}

Coordenação de Ensino Superior do Centro Paula Souza CESU

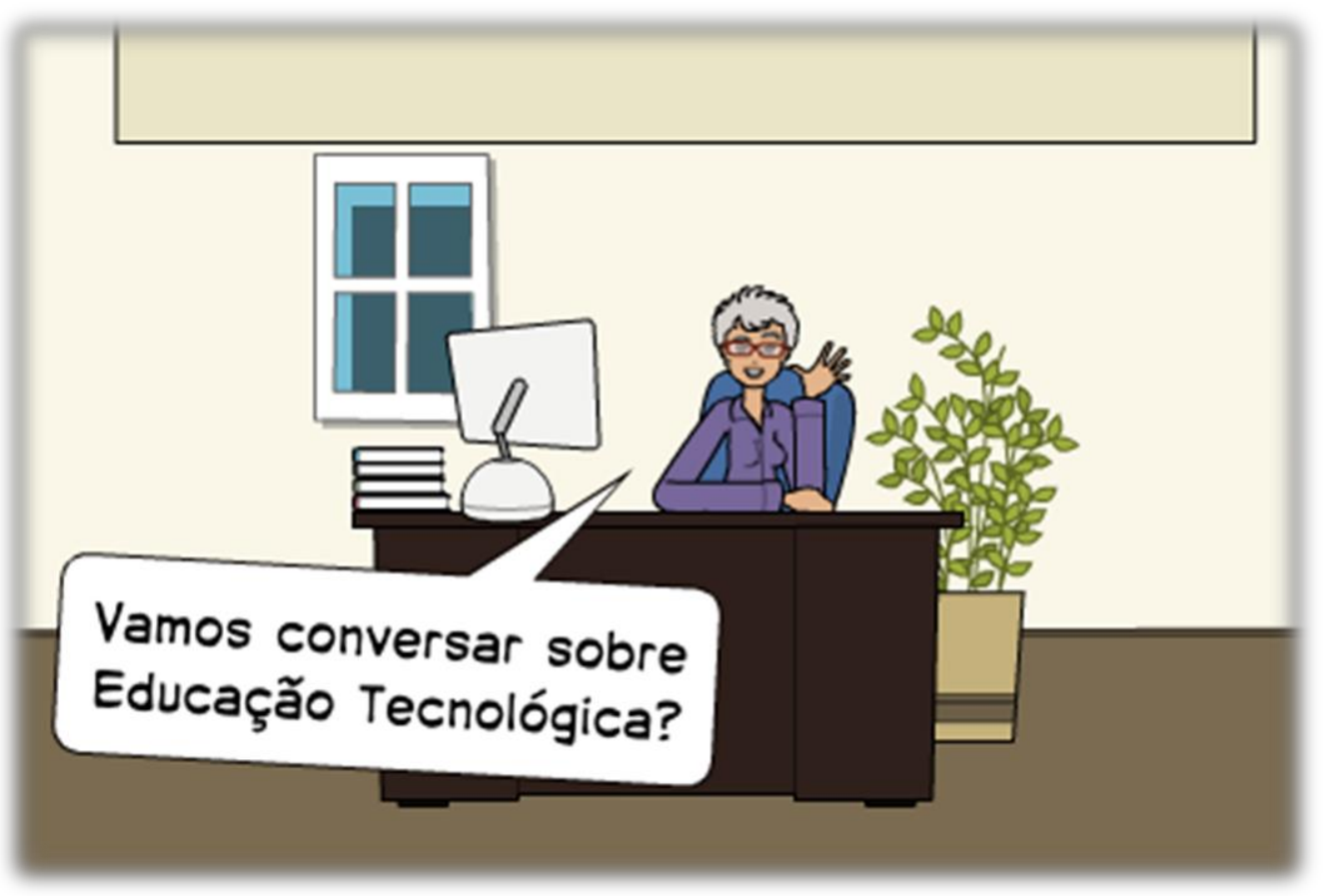

São Paulo 


\section{Sumário}

Prólogo

p. 6

Parte I - Um pouco de História

p. 10

Parte II - Um pouco de textos institucionais

p. 27

Parte III - Proposta de Discussão

p. 44

Referências

p. 46

Leituras Recomendadas

p. 47 

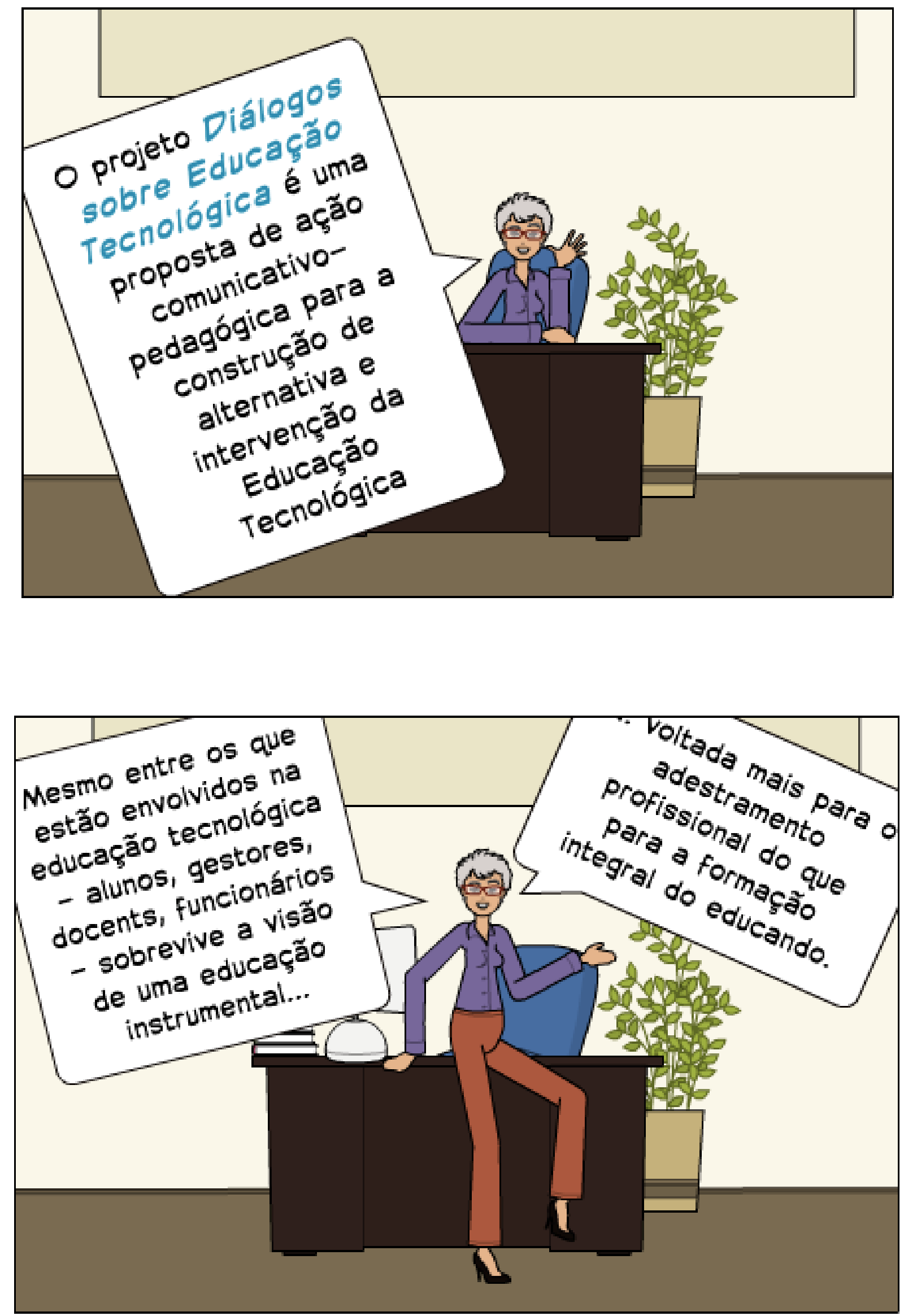

Prológo 
A educação tecnológica é educação de nível superior equivalente a qualquer outro curso de graduação, mas sobre ela recai ainda o forte estigma de educação de segunda mão, em consequência da dualidade estrutural que caracteriza nosso sistema.

Disso resulta muita distorção nos projetos pedagógicos de cursos e disciplinas, nas atividades de pesquisa e extensão e, consequentemente, no perfil de formação do egresso da educação tecnológica que acaba por não atender às expectativas nem de 'gregos' nem de 'troianos' - a educação propedêutica os considera "técnicos e estreitos" demais para a continuidade dos estudos em nível de pós graduação; e o mercado os quer mais flexíveis e polivalentes.

A proposta do Fórum Diálogos sobre Educação Tecnológica objetiva uma ação comunicativo-pedagógica para a construção de alternativas e intervenções transformadoras, centrada no diálogo, na informação historicamente contextualizada, no estudo das origens das diferentes concepções, na discussão sobre quais concepções orientam a educação tecnológica nas FATECs e sobre a reorientação necessária para o enfrentamento da dispersão, da evasão, dos baixos resultados e da falta de sintonia com os anseios da sociedade.

A ação, implantada e coordenada pela equipe pedagógica da CESU Coordenação de Ensino Superior do Centro Paula Souza -, consiste de 8 (oito) Fóruns a serem realizados com periodicidade mensal entre março e novembro de 2015 . O primeiro e o último Fóruns ocorrerão em encontros presenciais, abertos, públicos e gratuitos, e os demais se darão por participação on-line em plataforma a ser definida. Tem-se a preocupação de atender a objetivos estratégicos, que consistem em recuperar a potência do fórum na instauração de ambientes comunicativos democráticos e participativos, presenciais e virtuais; reinventar a prática do debate público, formativo e tolerante, como instância de criação, compartilhamento e 
divulgação de conhecimento e inovação; e promover ampla discussão sobre a potencialidade emancipadora da educação tecnológica - para o educando e para o país.

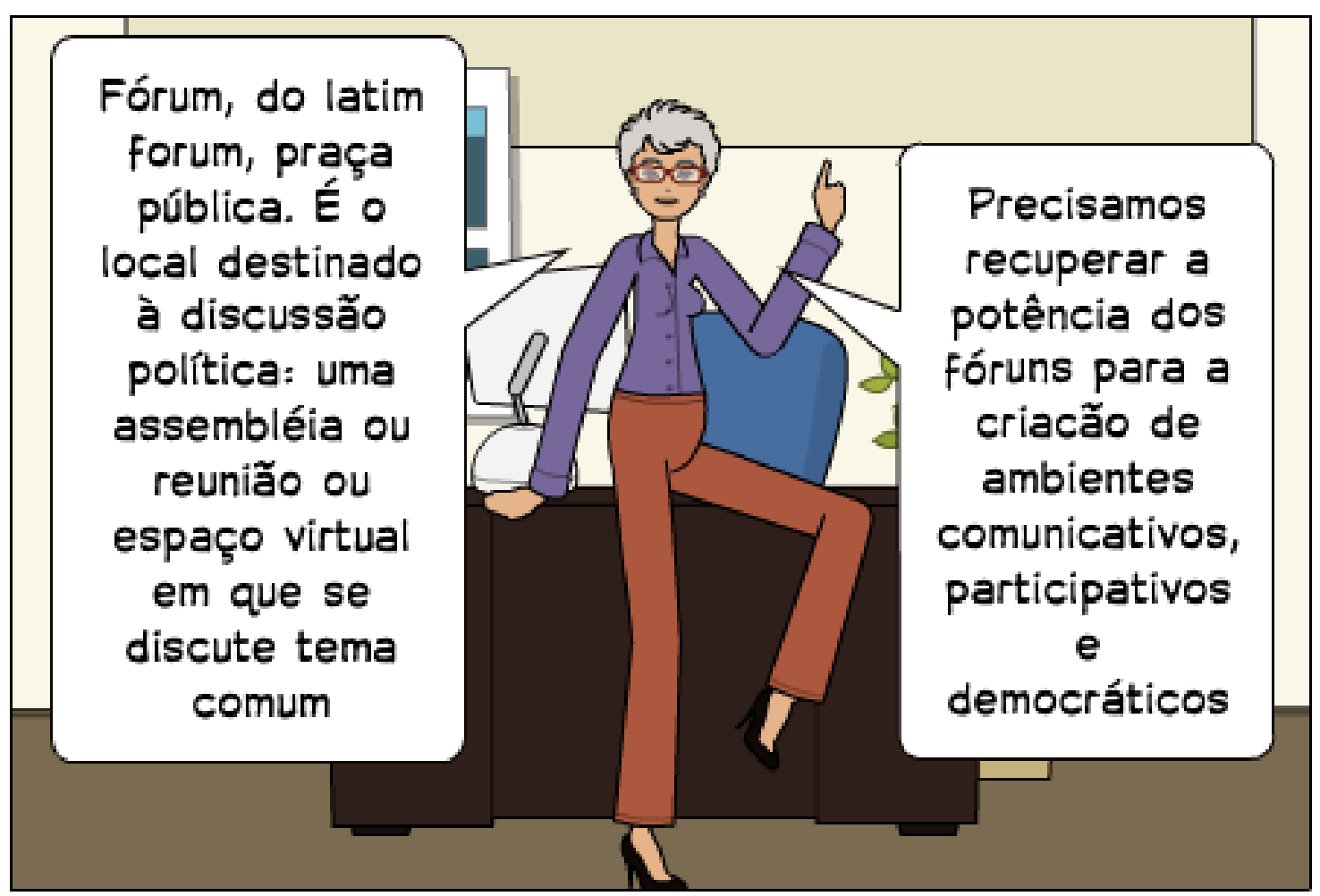




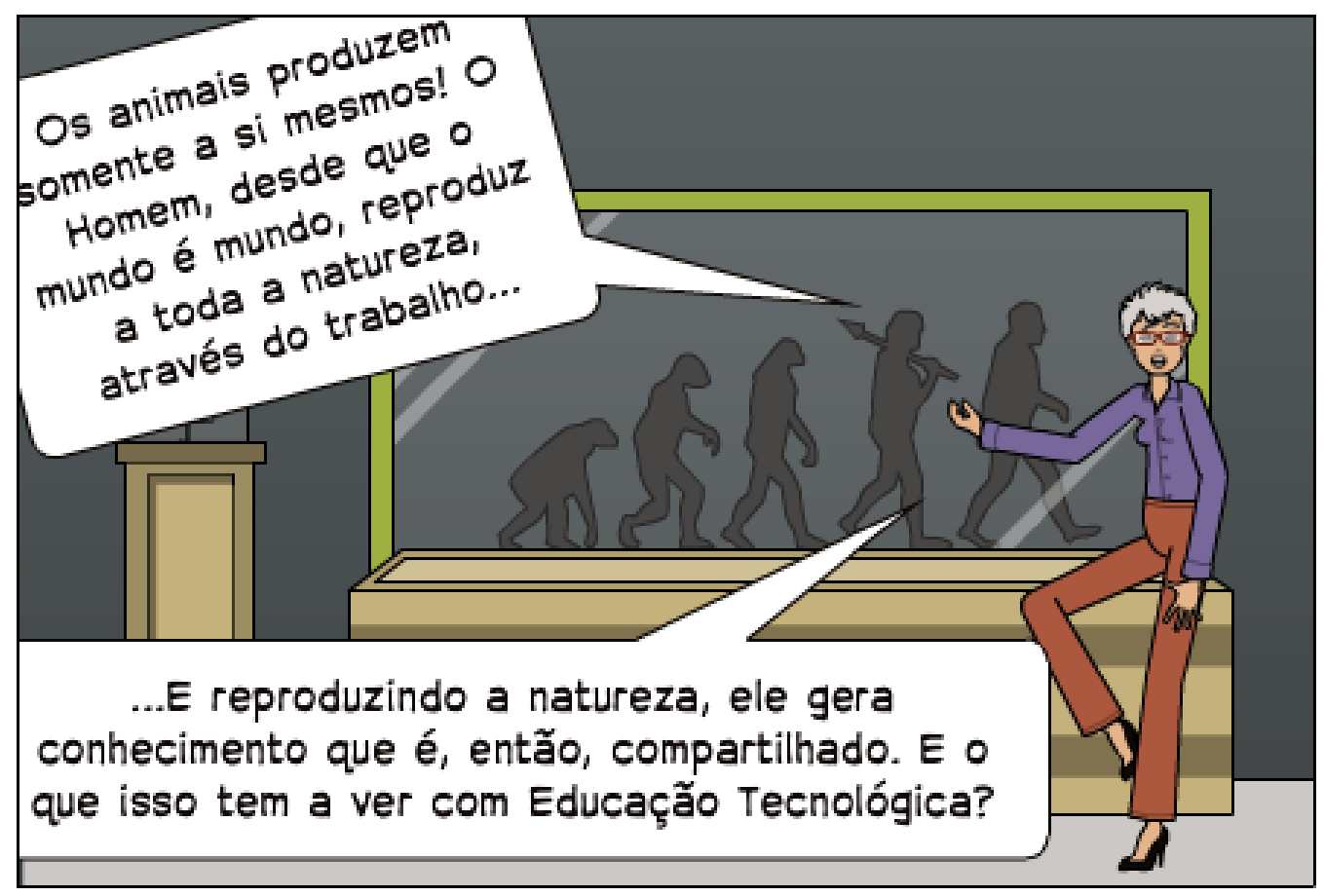

Desde quando se tem notícia, é caraterística fundamental do Homem trabalhar: o trabalho altera a natureza. Entretanto, costumamos esquecer que o trabalho e a educação, historicamente, andaram lado por longos períodos do desenvolvimento humano e de sua constituição como espécie dominante no planeta. Por que? O Homem domina o mundo por que controla a natureza e controla a natureza porque trabalha. Só por que trabalha? 
Tão fundamental e específica quanto a capacidade humana de transformar seu ambiente, está o fato de que o Homem, ao mesmo tempo em que produz conhecimento, produz sua difusão, seu compartilhamento.. A experiência prática humana não está historicamente dissociada do conhecimento, pelo contrário. $\mathrm{O}$ processo através do qual se rompeu a relação entre o viver, o trabalhar e o compartilhar passou por várias etapas até que a configuração dos paradigmas da educação e do trabalho se consolidaram como os temos hoje. Entretanto, para o Homem "primitivo"- e para que tenhamos deixado de sê-lo - trabalhar e educar eram atividades, de fato, sincrônicas. Seria, então, pré-histórica a origem da Educação Tecnológica?

Com a origem de sociedades cuja estrutura implicava em diferenciações sociais - escravos e senhores, patrícios e plebeus, etc. -, a relação entre aqueles dois polos igualmente fundamentais para o processo criativo nunca mais seria a mesma. $\mathrm{Na}$ Grécia antiga, por exemplo, a sociedade se dividia entre aqueles que eram cidadãos, e aqueles que não o eram (de maneira simplista, evidentemente) - e, por sua vez, aqueles que eram cidadãos gozavam de um bem que desde então tem sido muito caro às sociedades que vieram mais tarde: o tempo livre. Os cidadãos, detentores de tempo livre, frequentavam escolas ou, os "lugares do ócio", nos quais aprenderiam aquilo que Ihes permitiria continuar com suas atividades de cidadão, participando da vida pública da pólis. Por outro lado, os escravos - que não tinham tempo livre nem escola -, eram responsáveis pelo trabalho manual, que requeria habilidades específicas, para as quais eram treinados. Ou seja, nesse sentido, o trabalho que requer habilidades práticas específicas passa a não requerer educação - requer, porém, indivíduos adestrados.

A dualidade observada na antiguidade, continua a se manifestar durante a Idade Média, adaptando-se ao contexto da época, no qual a Igreja toma para si um papel fundamental na perpetuação do distanciamento entre o conhecimento e a experiência - ou, melhor, entre tipos específicos de conhecimento, e tipos igualmente específicos de experiência. A camada dirigente da sociedade medieval frequentava escolas, enquanto os artesãos eram ensinados pelos Mestres de Ofício - nesse contexto, o artesão trabalha, aprende e ensina, ainda que não tenha acesso à 
educação "intelectual" oferecida nas escolas. Ele tem, no entanto, absoluta consciência e domínio de todo o processo produtivo no qual seu trabalho - manual implica. A dualidade presente aqui, assim, situa-se entre uns que não precisam aprender a fazer (aprendem, portanto, a pensar), e uns que não precisam aprender a pensar, a não ser naquilo diretamente associado ao seu fazer.

Com a Revolução Industrial, institui-se um novo aspecto desse antigo processo, uma nova diferenciação. Uma das grandes reivindicações das Revoluções Burguesas, tais como a Revolução Francesa, foi por um sistema educacional público e gratuito para todos. As sociedades industriais passam a demandar sistemas de ensino universais por um simples motivo: as indústrias, as máquinas, demandavam conhecimentos específicos que não podiam ser ensinados pelos mestres de ofício artesanais. Isso não quer dizer, entretanto, que todo e qualquer indivíduo seria submetido à mesma educação, pelo contrário. A classe que emerge dominante passa a obter conhecimento intelectual que lhe permita compreender o processo produtivo - produzir tecnologia, desenvolvê-la, adminstrá-la etc. - enquanto o recém-surgido operariado aprende o suficiente para permitir seu restrito espaço de trabalho manual. A "novidade" é, portanto, que o trabalhador manual passa a desconhecer o processo produtivo em sua totalidade - a especialização de sua educação e de seu conhecimento permite a ele apenas, conhecer a etapa pela qual é responsável - sem que precise saber para que serve, o que a precede, e qual o seu custo, quais suas repercussões sociais... 


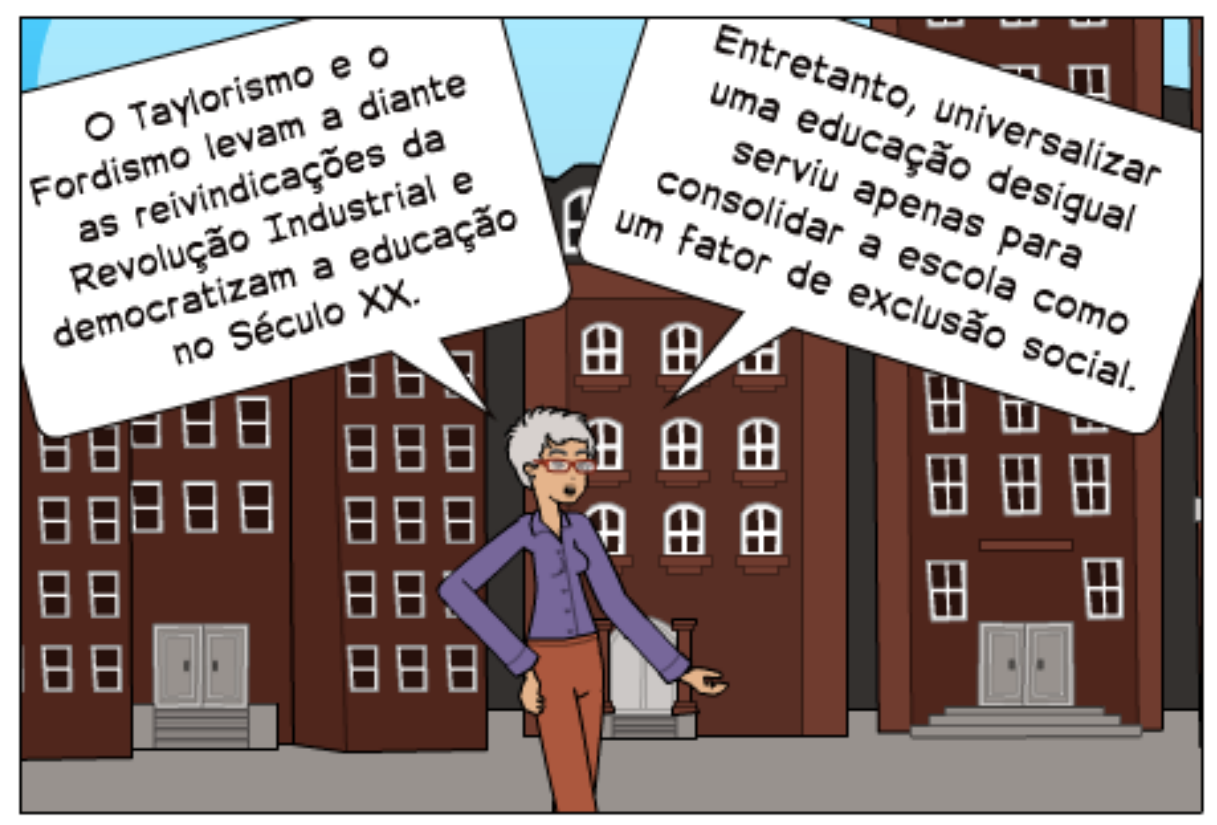

As consequências, portanto, de um processo de universalização e democratização da educação conduzido pelas necessidades imediatas dos mercados e das indústrias, respectivamente pelo Fordismo e, depois, pela evolução tecnológica do Taylorismo, não poderiam ser favoráveis ao bem estar (seja ele físico ou intelectual) do trabalhador. Atendendo a essas necessidades fluídas e excessivamente específicas, o trabalho se fez, cada vez mais, distante e descolado daquele que trabalhava - o que quer, inevitavelmente, dizer que cada vez mais o trabalhador não tinha acesso ao conhecimento associado à sua experiência: o trabalhador não conhecia seu processo de trabalho. Durante este processo, quase $3 / 4$ da população mundial foi desprofissionalizada, enquanto uma porcentagem mínima de indivíduos detinha o conhecimento "científico" para conduzir conscientemente os processos produtivos.

Não por acaso, talvez, reconheça-se na obra de Karl Marx propostas de implementação de Educação Tecnológica - ou Educação Politécnica -, como meios efetivos de emancipação da classe trabalhadora. A Educação Tecnológica não seria, como comumente se assume, uma proposta consolidadora das dualidades descritas - mas uma proposta de construção conjunta dos processos que foram rompidos tanto tempo atrás. Mais do que permitir àquele que recebe uma educação técnica o acesso à educação intelectual, a Educação Tecnológica teria por objetivo educar a respeito dos princípios científicos que orientam todo o processo de produção, ao passo que, 
simultaneamente, inicia o aluno em suas etapas operacionais. Em outras palavras, isto é afirmar uma educação cujo princípio norteador e educativo seria o trabalho e, portanto, afirmar uma proposta que, no limite, é emancipadora ao passo que permite ao trabalhador reconhecer a si mesmo em seu processo produtivo, e the devolve, por meio do conhecimento, autonomia e poder sobre sua força de trabalho.

\section{Texto de Apoio}

É de extrema importância, a partir da compreensão do que é e do que pode ser a Educação Tecnológica, compreender também como os processos históricos que edificaram as estruturas duais de educação e trabalho, encontram reflexos e especificidades no Brasil. Para tanto, o primeiro texto de apoio disponibilizado abaixo constrói um painel histórico da implementação das políticas públicas de educação e da educação profissional brasileiras.

\section{In: http://www.epsjv.fiocruz.br/dicionario/verbetes/edupro.html}

\section{EDUCAÇÃO PROFISSIONAL}

$\mathrm{Na}$ Grécia antiga, quando a sociedade se mantinha pela utilização do trabalho escravo, e a escola era o lugar do ócio e da prática de esportes, as funções intelectuais ficavam restritas a uma pequena parcela da sociedade. Na Idade Média, a sociedade era sustentada pelo trabalho servil, pelo cultivo da terra, desenvolvido segundo técnicas simples e reiterativas que não exigiam a incorporação de conhecimentos sistemáticos. "Quem se dedicava ao trabalho intelectual era a parcela dos intelectuais, fundamentalmente concentrada no clero. As escolas, naquele momento histórico, se restringiam a essa parcela e, por isso, eram chamadas Escolas Monacais" (Saviani, 2003, p. 134). Na Idade Média a transmissão dos conhecimentos profissionais estava situada fora dos estabelecimentos escolares os quais eram empregados apenas para o melhor desenvolvimento intelectual da juventude.

À revolução industrial correspondeu uma Revolução Educacional: aquela colocou a máquina no centro do processo produtivo; esta erigiu a escola em forma principal e dominante de educação (Saviani, 2006). A transmissão, via escola, de conhecimentos técnicos e científicos, corresponde ao aparecimento de novas divisões e novas funções na hierarquia social do trabalho. As primeiras escolas de engenheiros são escolas para a formação de quadros funcionais especializados para o Estado. Essas escolas de ciências aplicadas articulam os conhecimentos técnico-científicos e as práticas sociais. A partir delas o conhecimento é difundido, mas elas são também locais de articulação entre o saber e o poder. O aparecimento dessas escolas se faz acompanhar de uma redefinição dos conteúdos a serem transmitidos, o que, por sua vez, leva a uma reorganização dos conhecimentos exigidos. 
No dizer de Manacorda (1994, p. 246), fábrica e escola nascem juntas, em um movimento que implica também a "passagem definitiva da instrução das Igrejas para os Estados": "as leis que criam a escola de Estado vêm juntas com as leis que suprimem a aprendizagem corporativa" (Manacorda, 1994, p. 249). É nesse momento de mudança não só do modo de produção, mas também do modo de vida do homem, que nasce o ideal de escola elementar gratuita e para todos, tanto na América do Norte como na França revolucionária, pós-1789. O período revolucionário afirma o direito de todos à educação e renova seus conteúdos.

A incorporação de uma cultura técnico-científica voltada para a preparação profissional aos conteúdos escolares até então essencialmente especulativos e teóricos implica uma revolução, que para Petitat (1994) talvez seja a mais importante desde a própria aparição da escola. Esta cultura, em um primeiro momento, não encontrou espaço nas escolas então existentes, e surgiram novas instituições: academias, escolas técnicas e profissionais.

No Brasil, a predominância de uma "mentalidade jurídico-profissional, voltada inteiramente para as carreiras liberais e para as letras, a política e a administração" (Azevedo, 1996, p.626) faz com que o ensino técnico-profissional seja relegado a um plano secundário. De um lado, o encargo dos trabalhos pesados dado inicialmente aos índios e aos escravos; de outro, a espécie de educação que os jesuítas ofereciam criou, no Brasil, uma mentalidade que levou ao desprezo pelo ensino de ofícios. Essa mentalidade imperou ao longo de nossa história, da descoberta até quase a República.

Durante esse período, a aprendizagem profissional era destinada aos órfãos e desvalidos, não fazendo parte das ações desenvolvidas nas escolas; não era entendida como ação afeta à instrução pública, mas como ação de caridade. Mais tarde, o ensino profissional é incluído no conjunto geral da instrução, mas entendido como necessariamente de grau elementar, continuando a ser considerado como deprimente e desmoralizante.

Os liceus de artes e ofícios, criados em 1858, traziam em seus programas uma nova filosofia, uma outra maneira de encarar o ensino técnico-profissional, que deixava de ser meramente assistencial e elementar. A multiplicação de liceus de artes e ofícios em várias províncias parece indicar que em todo o país surgiam novas idéias com relação ao ensino necessário à indústria. A abolição da escravatura também contribuiu para uma nova maneira de encarar o trabalho que não fosse intelectual.

No entanto, a velha concepção destinando esse tipo de ensino aos deserdados da fortuna persiste mesmo depois da instauração da República. Quando Nilo Peçanha, em 1909, cria as escolas de aprendizes artífices (Decreto n. 7.566/09), destina essas escolas aos 'deserdados da fortuna'. A criação dessa rede de escolas é, segundo Ciavatta (1990, p. 330), a expressão histórica, naquele momento, "da questão social manifesta no desamparo dos trabalhadores e de seus filhos e na ausência de uma política efetiva de educação primária".

O contexto da industrialização e da revolução de 1930 destaca a relação entre trabalho e educação como problema fundamental. A Constituição de 1937, entretanto, ainda explicita claramente o dualismo escolar e a destinação do ensino profissional aos menos favorecidos:

O ensino pré-vocacional e profissional destinado às classes menos favorecidas é, em matéria de educação, o primeiro dever do Estado. Cumpre-Ihe dar execução a esse dever, fundando institutos de ensino profissional e subsidiando os de iniciativa dos Estados, dos Municípios e dos indivíduos ou associações particulares e profissionais.

O Manifesto dos Pioneiros identifica a existência, no Brasil, de dois sistemas 
paralelos e divorciados de educação, fechados em compartimentos estanques e incomunicáveis:

O sistema de ensino primário e profissional e o sistema de ensino secundário e superior teriam diferentes objetivos culturais e sociais, constituindo-se, por isso mesmo, em instrumentos de estratificação social. A escola primária e a profissional serviriam à classe popular, enquanto que a escola secundária e a superior à burguesia. (Cunha, 1997, p. 13)

Naquela época, as escolas profissionais da Prefeitura do Distrito Federal exigiam, para matrícula, que os alunos apresentassem atestado de pobreza. Embora as escolas técnicas profissionais continuassem destinadas aos pobres, percebia-se nitidamente uma mudança na concepção da 'educação profissional', na medida em que essas escolas passavam a ser encaradas como escolas formadoras de técnicos capazes de desempenhar qualquer função na indústria. "O trabalho e o assistencialismo constituem-se fundamentos de processos educativos associados à 'escola do trabalho', segundo dois eixos fundamentais: a regeneração pelo trabalho e o trabalho para a modernização da produção" (Ciavatta, 1990, p. 328).

A industrialização, a partir principalmente dos anos 30 do último século, modifica lentamente a sociedade brasileira, tornando necessária uma nova proposta de educação: fazse necessário preparar trabalhadores para a indústria, dentro de uma nova ordem social, gerada pela acumulação do capital. A necessidade de preparação de mão-de-obra para a indústria implica uma mudança de concepção do ensino profissional. De uma aprendizagem mais próxima do ofício era necessário passar para uma aprendizagem que introduzisse o domínio das técnicas, da parcelarização do trabalho e da adaptação à máquina, de maneira a disciplinar a força de trabalho e adequá-la à organização fabril. Nesse quadro, a 'educação profissional' situa-se em um contexto maior de demandas de uma nova sociedade: a sociedade industrial. Além de preparar tecnicamente para o trabalho, é preciso também disciplinar os jovens para as atividades produtivas e a divisão do trabalho.

Nos anos 30 e de novo nos anos 40 reforma-se o ensino secundário. A partir de 1942 são baixadas por decreto-lei as conhecidas "leis orgânicas da educação nacional" para o ensino secundário, o ensino industrial, o ensino comercial, o ensino primário, o ensino normal e o ensino agrícola. A Constituição de 1937, ao determinar que o ensino vocacional e pré-vocacional são dever do Estado, a ser cumprido com a colaboração das empresas e dos sindicatos econômicos, propiciou a definição das Leis Orgânicas do Ensino Profissional e a criação de entidades especializadas como o Serviço Nacional de Aprendizagem Industrial (Senai) e o Serviço Nacional de Aprendizagem Comercial (Senac), bem como a transformação das antigas escolas de aprendizes artífices em escolas técnicas federais.

No conjunto das Leis Orgânicas da Educação Nacional, o ensino secundário e o ensino normal têm como objetivo "formar as elites condutoras do país", enquanto para o ensino profissional define-se como objetivo oferecer "formação adequada aos filhos dos operários, aos desvalidos da sorte e aos menos afortunados, aqueles que necessitam ingressar precocemente na força de trabalho". A herança dualista perdura e é explicitada (CNE, 1999).

Aprofunda-se, na época, a ênfase na participação da escola na formação da mãode-obra de maneira a contribuir para o aumento da produtividade do trabalho e da riqueza nacional. A Revolução Industrial, o desenvolvimento do capitalismo e a incorporação do conhecimento e da ciência ao processo produtivo trouxeram uma nova concepção sobre o valor do trabalho e sobre o caráter teórico-prático do fazer e da técnica.

No início da República, o ensino secundário, o normal e o superior, eram competência do Ministério da Justiça e dos Negócios Interiores, e o ensino profissional, por 
sua vez, era afeto ao Ministério da Agricultura, Indústria e Comércio. A junção dos dois ramos de ensino, a partir da década de 1930, no âmbito do mesmo Ministério da Educação e Saúde Pública foi apenas formal, não ensejando, ainda, a necessária e desejável 'circulação de estudos' entre o acadêmico e o profissional. Apenas na década de 1950 é que se passou a permitir a equivalência entre os estudos acadêmicos e profissionalizantes. Em 1961, com a promulgação da Lei de Diretrizes e Bases da Educação Nacional (Lei n. 4024 de 20 de dezembro de 1961) fica estabelecida a completa equivalência entre os cursos técnicos e o curso secundário para efeitos de ingresso nos cursos superiores. As lutas políticas em torno da primeira Lei de Diretrizes e Bases da Educação Nacional estão na origem das Leis de Equivalência que progressivamente equiparam os estudos acadêmicos aos profissionais em termos de prosseguimento de estudos no nível superior.

A Lei n. 5.692/71 reformou o ensino primário e secundário. Estabeleceu compulsoriamente a profissionalização como finalidade única para o ensino de $2^{\circ} \mathrm{grau}$. Em decorrência desta lei, a 'educação profissional' deixou de estar limitada a estabelecimentos especializados. Segundo Cunha (1998), com a implantação dessa lei, as escolas técnicas viram-se procuradas por levas de estudantes que pouco ou nenhum interesse tinham por seus cursos profissionais. Paradoxalmente, a profissionalização compulsória do ensino de 20 grau trouxe como efeito o reforço da função propedêutica das escolas técnicas, que se transformaram numa alternativa de ensino público para estudantes que apenas pretendiam se preparar para o vestibular. Onze anos depois, a Lei 7.044/ 82 retirou a obrigatoriedade da habilitação profissional no ensino de 20 grau. Em decorrência, a 'educação profissional' voltou a ficar restrita aos estabelecimentos especializados.

A Lei n. 9.394/96, atual Lei de Diretrizes e Bases (LDB), configura a identidade do ensino médio como uma etapa de consolidação da educação básica e dispõe que "a educação profissional (...) conduz ao permanente desenvolvimento de aptidões para a vida produtiva". Pela primeira vez, consta em uma lei geral da educação brasileira um capítulo específico sobre 'educação profissional'. Em 17 de abril de 1997, o governo federal baixou o Decreto $n$. 2.208, regulamentando os dispositivos da LDB referentes à 'educação profissional', definindo seus objetivos e níveis, além de estabelecer orientações para a formulação dos currículos dos cursos técnicos. O decreto especifica três níveis de 'educação profissional': o básico, o técnico e o tecnológico. A reforma dos anos 90 proíbe o desenvolvimento do ensino técnico integrado ao ensino médio e define a 'educação profissional' como necessariamente paralela e complementar à educação básica.

$\mathrm{Na}$ proibição do desenvolvimento do ensino técnico integrado ao ensino médio evidencia-se de forma exemplar as principais características da reforma da 'educação profissional' dos anos 90 , no Brasil: o retorno formal ao dualismo escolar, na medida em que se aparta a 'educação profissional' da educação regular; na concepção de educação que embasa essa reforma - a ruptura entre o pensar e o agir e o aligeiramento da educação profissional; a subsunção da escola à cultura do mercado na formação do cidadão produtivo (Frigotto \& Ciavatta, 2006). Essa concepção de educação se insere no contexto de hegemonia das políticas neoliberais e se afina à redução do papel do Estado. Retoma-se com essa reforma uma visão dualista do sistema educacional, destinando-se explicitamente a 'educação profissional' ao atendimento de uma determinada classe social.

O Decreto n. 5.154, de julho de 2004, revogou o Decreto n. 2.208/97 e restituiu a possibilidade de articulação plena do ensino médio com a 'educação profissional', mediante a oferta de ensino técnico integrado ao ensino médio. Manteve, entretanto, as alternativas anteriores que haviam sido fortalecidas e ampliadas com o Decreto n. 2.208/97 e expressavam a histórica dualidade estrutural da educação brasileira.

O debate em torno das concepções que estavam presentes nas discussões que antecederam a Lei n. 9.394/96, no final dos anos 80, é retomado nesse início do século XXI 
de maneira a contemplar uma proposta de articulação entre ciência, cultura e trabalho, como elementos norteadores de uma nova política educacional. A expansão e democratização da 'educação profissional' no Brasil assume grande relevância nesse contexto em razão das expectativas de elaboração de uma nova política pública para o setor, no âmbito de um projeto nacional de desenvolvimento.

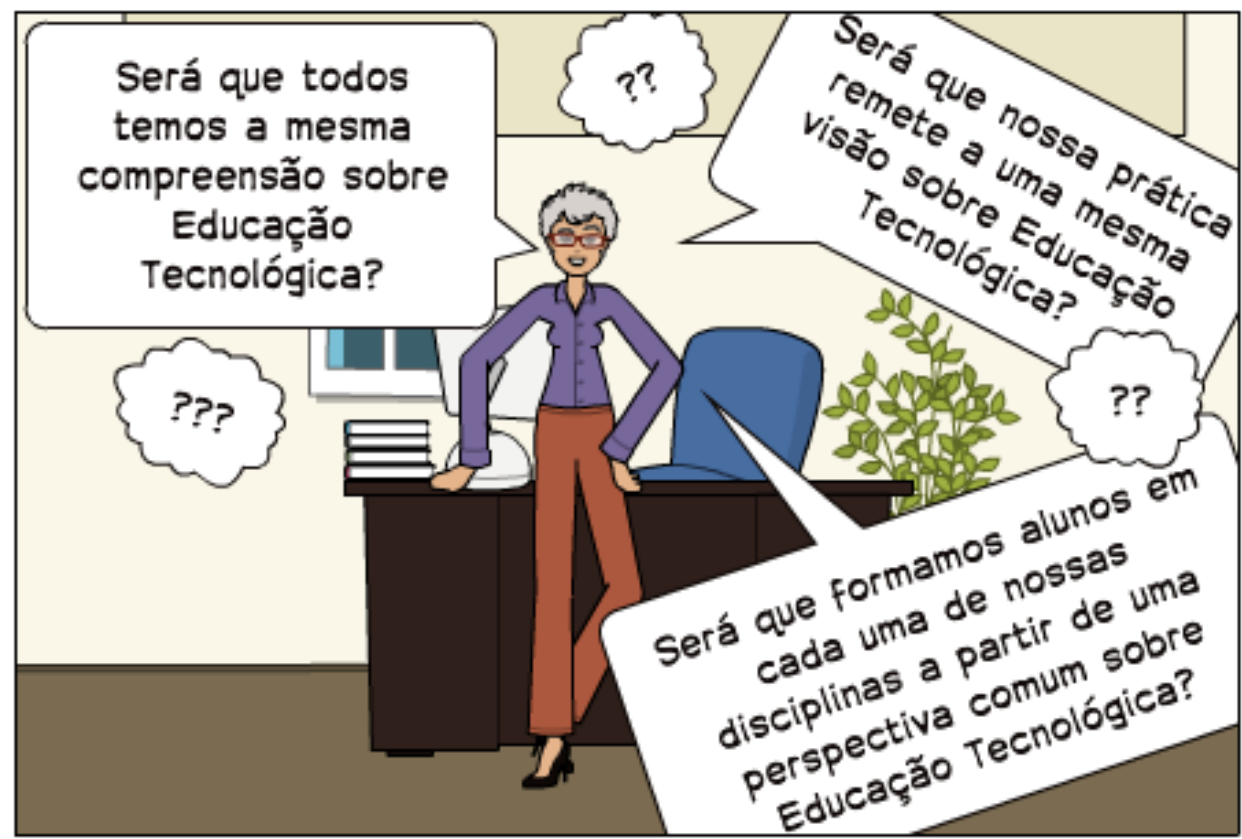


Primeiro, vamos dar uma olhada numa compilação de trechos de documentos institucionais sobre a questão.

1. O que o PPI - Projeto Pedagógico Institucional - do Centro Paula Souza nos diz:

Lá, entre as páginas 34 e 37 deste documento institucional norteador, vamos encontrar algumas definições sobre o tipo de educação que fazemos:

\subsection{Princípios Filosóficos, Teórico-Metodológicos e Acadêmicos da Instituição}

Coerente com os seus valores, o Centro Paula Souza orienta suas ações com base nos seguintes princípios:

A educação superior deve contribuir para a formação do ser humano pleno, cidadão responsável e ético, indo além da simples formação e capacitação profissional.

A educação superior deve contribuir para a construção do conhecimento e inovação que possa resolver problemas da sociedade brasileira na busca por qualidade de vida.

$\checkmark \quad$ O desenvolvimento de habilidades e atitudes profissionais deve ser o a tônica em todos os cursos, complementando a formação do "Ser" com a aprendizagem do "Fazer", focado nas demandas da sociedade e mercado.

A portabilidade do conhecimento constitui linha mestre na formulação dos Projetos Pedagógicos, caracterizando o sentimento da integração dos conteúdos entre seus diversos cursos. O aluno é estudante do Centro Paula Souza e seus conhecimentos correlatos são aproveitados como parcela de seus currículos. Permite a capacidade intrínseca de atuar em múltiplos ambientes com a habilidade de ajustarse e agregar valor de forma continuada. [...] 
As limitações da aprendizagem impostas pela sala de aula devem ser suplementadas por atividades autônomas dos estudantes que contribuam para que $o$ aluno se aproprie do conhecimento e de sua produção, conquistando assim a independência necessária para uma atuação constante e preocupada com seu próprio e contínuo desenvolvimento.

$A$ aprendizagem não se restringe mais ao ambiente acadêmico, mediante a ausência dos limites impostos pelas novas tecnologias e a possibilidade do uso do Ensino a Distância como complemento às atividades presenciais, que contribui para a interdisciplinaridade e a transdisciplinaridade.

Esforço continuado para a criação e manutenção de um ambiente favorável à aprendizagem, estabelecido como resultado da qualidade dos relacionamentos humanos entre todas as partes interessadas.

A produção do conhecimento deve ser uma condição "sine qua non" para o desenvolvimento de cursos de graduação e, no caso da graduação tecnológica, ela deve estar embasada na inovação e na sustentabilidade do planeta, servindo, ainda, como fator de diminuição das desigualdades sociais e econômicas da população. [...]

\section{Políticas de Ensino}

No ensino superior, são apontadas como diretrizes para as ações estratégicas a serem desenvolvidas:

\section{[...]}

Utilização intensiva de tecnologias de informação e comunicação com a finalidade de melhorar a qualidade do ensino e também de promover maior disseminação social da educação tecnológica por meio da ampliação da abrangência geográfica de oferta dos cursos.

Valorização da competência profissional do corpo docente, tendo como referência o conjunto de habilidades e atitudes a serem desenvolvidas em cada componente curricular, conforme o prescrito no Projeto Pedagógico de cada curso. 
Existência de disciplinas comuns aos vários cursos que garantam uma formação básica condizente com o que se espera de um indivíduo formado em nível superior no nosso século.

Flexibilidade para que o aluno possa eleger disciplina ou conjunto de disciplinas oferecidas em outros cursos, que possam ser consideradas como eletivas, permitindo ao aluno aprofundar/diversificar os estudos de seu maior interesse.

Adoção de práticas pedagógicas que favoreçam a inter e a transdisciplinaridade pela integração de conteúdos em atividades acadêmicas inovadoras e direcionadas para a formação profissional. [...]

Adoção de atividades autônomas e projetos integradores como forma de estender a aprendizagem para além dos limites físico-temporais das aulas presenciais. [...]

Fortalecimento da integração entre alunos, professores e funcionários, através de programas permanentes e de ações específicas que favoreçam a criação de um ambiente harmônico e coeso. [...]

Avaliação continuada do ambiente profissional regional para a criação e manutenção de cursos de pós-graduação coerentes com as demandas identificadas.

$\checkmark \quad$ Utilização do programa de pós-graduação como instrumento de atualização e de especialização profissional, parte integrante das propostas de educação continuada.

Alinhamento entre as atividades de pós-graduação e as propostas pedagógicas constantes dos Projetos Pedagógicos dos cursos de graduação, favorecendo o desenvolvimento de projetos complexos e integrados. [...]" 


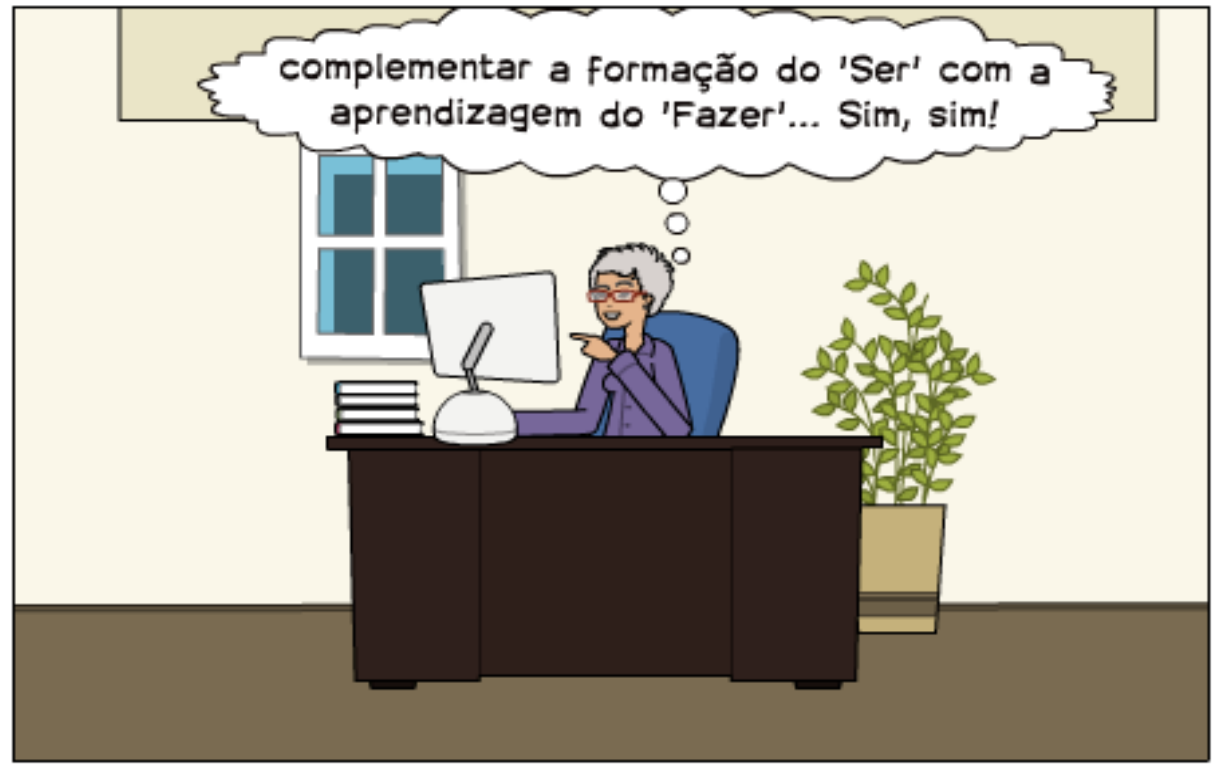


Ao que parece, o PPI do Centro Paula Souza faz um esforço para 'desestigmatizar' a educação profissional, desconstruindo aquela ideia ultrapassada de que o estudante de educação técnica e tecnológica são meros "apertadores de parafusos", perspectiva que não tem mais espaço nas sociedades da informação e da comunicação.

Nosso PPI está em consonância, como não poderia deixar de ser, com outro documento institucional - desta vez, do MEC - que estabelece as Diretrizes Curriculares para os Cursos Superiores de Tecnologia.

\section{O que dizem as Diretrizes Nacionais:}

Art. $2^{\circ}$ Os cursos de educação profissional de nível tecnológico serão designados como cursos superiores de tecnologia e deverão:

I - incentivar o desenvolvimento da capacidade empreendedora e da compreensão do

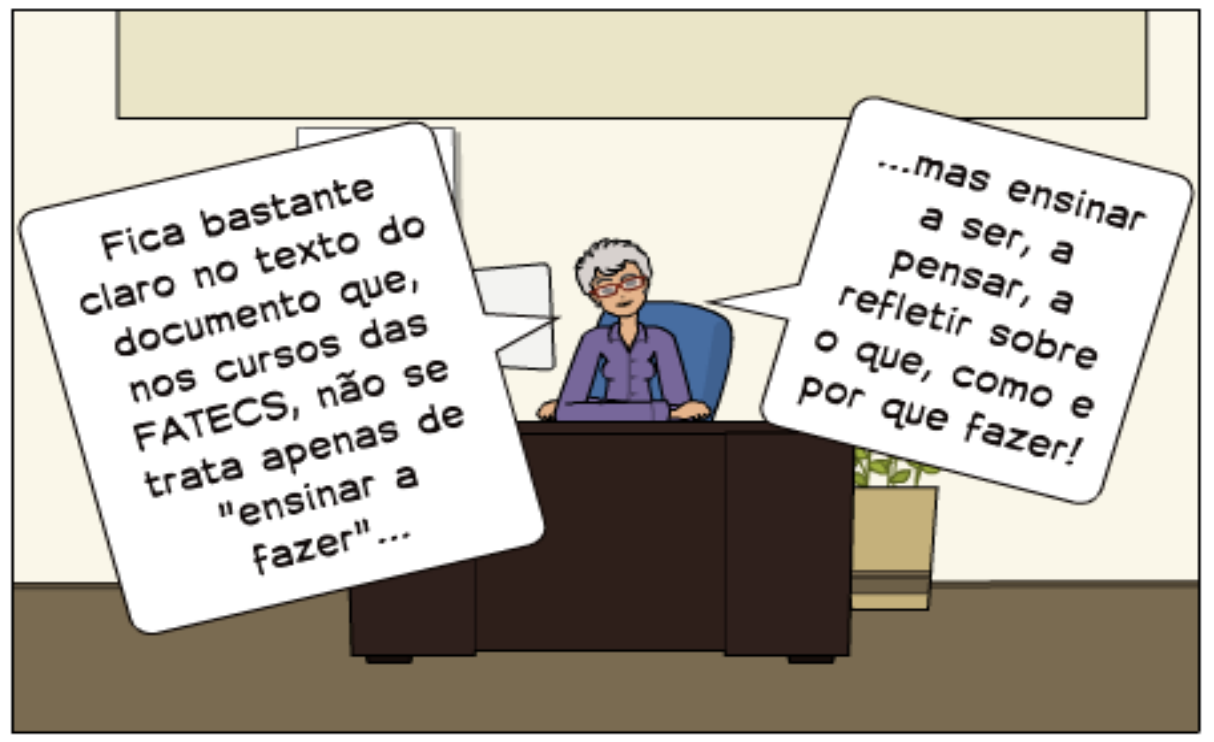


processo tecnológico, em suas causas e efeitos;

II - incentivar a produção e a inovação científico-tecnológica, e suas respectivas aplicações no mundo do trabalho;

III - desenvolver competências profissionais tecnológicas, gerais e específicas, para a gestão de processos e a produção de bens e serviços;

IV - propiciar a compreensão e a avaliação dos impactos sociais, econômicos e ambientais resultantes da produção, gestão e incorporação de novas tecnologias;

$\boldsymbol{V}$ - promover a capacidade de continuar aprendendo e de acompanhar as mudanças nas condições de trabalho, bem como propiciar o prosseguimento de estudos em cursos de pós graduação;

VI - adotar a flexibilidade, a interdisciplinaridade, a contextualização e a atualização permanente dos cursos e seus currículos;

VII - garantir a identidade do perfil profissional de conclusão de curso e da respectiva organização curricular.

Art. $3^{\circ}$ São critérios para o planejamento e a organização dos cursos superiores de tecnologia:

I - o atendimento às demandas dos cidadãos, do mercado de trabalho e da sociedade;

II - a conciliação das demandas identificadas com a vocação da instituição de ensino e as suas reais condições de viabilização;

III - a identificação de perfis profissionais próprios para cada curso, em função das demandas e em sintonia com as políticas de promoção do desenvolvimento sustentável do País. 


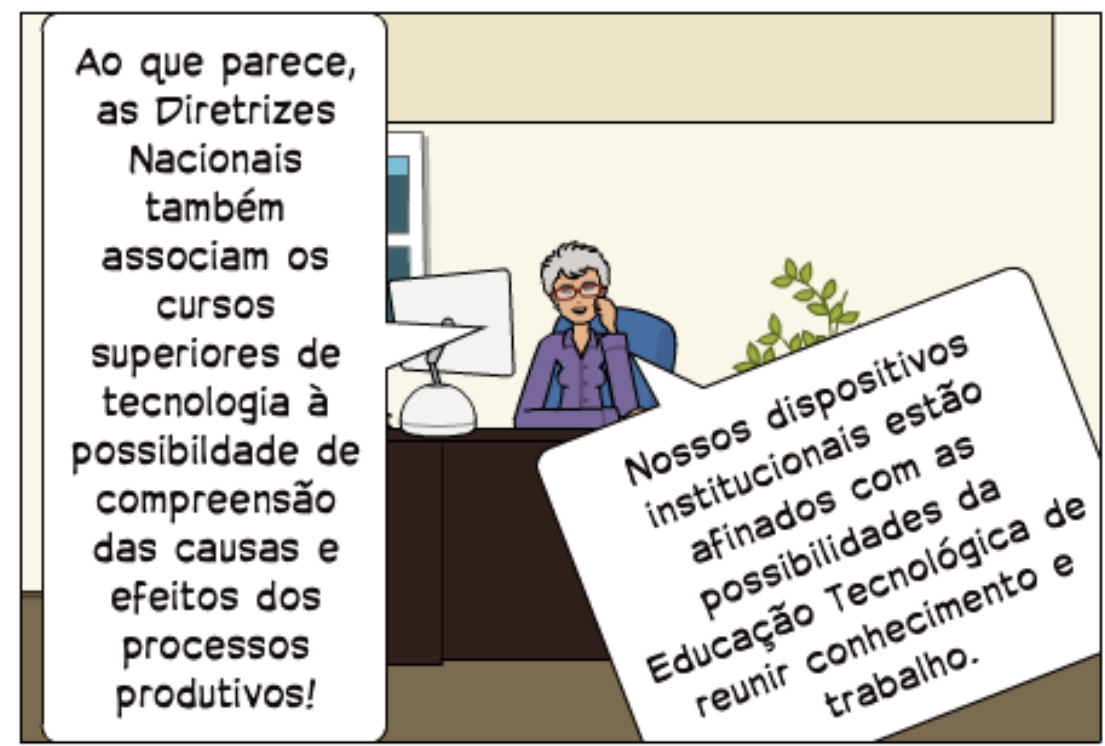

3. E, vejamos ainda, o que diz o parecer do CNE 29/2002, sobre as

\section{Diretrizes:}

p. 14 A Educação Profissional não é mais concebida como um simples instrumento de política assistencialista ou linear ajustamento às demandas do mercado. Ela é concebida, agora, como importante estratégia para que os cidadãos tenham efetivo acesso às conquistas científicas e tecnológicas da sociedade, que tanto modificam suas vidas e seus ambientes de trabalho. Para tanto, impõe-se a superação do enfoque tradicional da educação profissional, encarada apenas como preparação para a execução de um determinado conjunto de tarefas, em um posto de trabalho determinado. A nova educação profissional, especialmente a de nível tecnológico, requer muito mais que a formação técnica específica para um determinado fazer. Ela requer, além do domínio operacional de uma determinada técnica de trabalho, a compreensão global do processo produtivo, com a apreensão do saber tecnológico e do conhecimento que dá forma ao saber técnico e ao ato de fazer, com a valorização da cultura do trabalho e com a mobilização dos valores necessários à tomada de decisões profissionais e ao monitoramento dos seus próprios desempenhos profissionais, em busca do belo e da perfeição 
p. 15 Os Referenciais Curriculares Nacionais para a Educação Profissional de Nível Técnico, elaborados e divulgados pelo MEC, complementando o trabalho desenvolvido pelo CNE, apresentou nos seguintes termos o novo paradigma da educação profissional, com o qual se deve trabalhar e que deve reposicionar os currículos escolares tanto dos cursos técnicos quanto dos cursos superiores de tecnologia, centrados no compromisso institucional com o desenvolvimento de competências profissionais: "Emerge, no novo paradigma da educação e, de forma mais marcante, na educação profissional, o conceito de competência, mesmo que ainda polêmico, como elemento orientador de currículos, estes encarados como conjuntos integrados e articulados de situações-meio, pedagogicamente concebidos e organizados para promover aprendizagens profissionais significativas. Currículos, portanto, não são mais centrados em conteúdos ou necessariamente traduzidos em grades de disciplinas. A nova educação profissional desloca o foco do trabalho educacional do ensinar para o aprender, do que vai ser ensinado para o que é preciso aprender no mundo contemporâneo e futuro". (grifo nosso)

p. 17/18 Os cursos de graduação em tecnologia [...] Têm por finalidade $O$ desenvolvimento de competências profissionais que permitam tanto a correta utilização e aplicação da tecnologia e o desenvolvimento de novas aplicações ou adaptação em novas situações profissionais, quanto o entendimento das implicações daí decorrentes e de suas relações com o processo produtivo, a pessoa humana e a sociedade.

O objetivo a ser perseguido é o do desenvolvimento de qualificações capazes de permitir ao egresso a gestão de processos de produção de bens $e$ serviços resultantes da utilização de tecnologias e o desenvolvimento de aptidões para a pesquisa tecnológica e para a disseminação de conhecimentos tecnológicos. Em consequência, os cursos de graduação em tecnologia deverão:

desenvolver competências profissionais tecnológicas para a gestão de processos de produção de bens e serviços;

promover a capacidade de continuar aprendendo e de acompanhar as mudanças nas condições de trabalho, bem como propiciar o prosseguimento de estudos em cursos de pós-graduação; 
cultivar o pensamento reflexivo, a autonomia intelectual, a capacidade empreendedora e a compreensão do processo tecnológico, em suas causas e efeitos, nas suas relações com o desenvolvimento do espírito científico;

$\checkmark$ incentivar a produção e a inovação científico-tecnológica , a criação artística e cultural e suas respectivas aplicações no mundo do trabalho;

adotar a flexibilidade, a interdisciplinaridade, a contextualização e a atualização permanente dos cursos e seus currículos;

p. 21 desde o início da década de 90, as instituições de educação profissional passaram a discutir intensamente como enfrentar, com propriedade, os desafios trazidos pelo desenvolvimento e pela influência de tecnologias como as da microinformática, telemática e mecatrônica. Em um quadro que parece caracterizado pela transformação contínua, o próprio processo de aprendizado precisa ser permanente e flexível. Já não é suficiente, como nos métodos definidos pelo taylorismo, dominar um certo conjunto de procedimentos de produção e reproduzilos mecanicamente a cada dia. O dinamismo das novas tecnologias demanda agilidade e flexibilidade em relação à mudança. O que se passa a exigir do trabalhador especializado é sobretudo a capacidade de aprender

p. 24/25 O Parecer CNE/CES $n^{\circ} 776 / 97$, procurou sinalizar a necessidade de se promover formas de aprendizagem que contribuam efetivamente para reduzir a evasão, bem como desenvolvam no aluno sua criatividade, análise crítica, atitudes e valores orientados para a cidadania, atentas às dimensões éticas e humanísticas. assim chamado conteudismo é também apontado como característica superada pela proposta educacional em implantação, pela superação do enfoque em cursos reduzidos à condição de meros instrumentos de transmissão de conhecimento e informações. Doravante, devem orientar-se para oferecer uma sólida formação básica, preparando o futuro graduado para enfrentar os desafios decorrentes das rápidas transformações da sociedade, do mercado de trabalho e das condições de exercício profissional em situações cambiantes. 
p. 26/27 É preciso superar o enfoque tradicional que a vê a educação profissional exclusivamente como treinamento e capacitação técnica para um determinado posto de trabalho, em congruência direta com um emprego e remuneração fixos. Não é mais suficiente aprender a fazer. Não basta apenas a técnica do trabalho.

O que se busca é o cultivo do pensamento reflexivo, com crescentes graus de autonomia intelectual e de ação, bem como a capacidade empreendedora e a compreensão do processo tecnológico, em suas causas e efeitos, nas suas relações com o desenvolvimento do espírito científico e tecnológico.[...] Essa mudança de paradigma traz em seu bojo elementos de uma sensibilidade diferente para as questões que envolvem o mundo do trabalho e todos seus agentes, o que implica na organização de currículos de acordo com valores que fomentem a criatividade, a iniciativa, a liberdade de expressão, a intuição, a inovação tecnológica, a descoberta científica, a criação artística e cultural, bem como suas respectivas aplicações técnicas e tecnológicas.

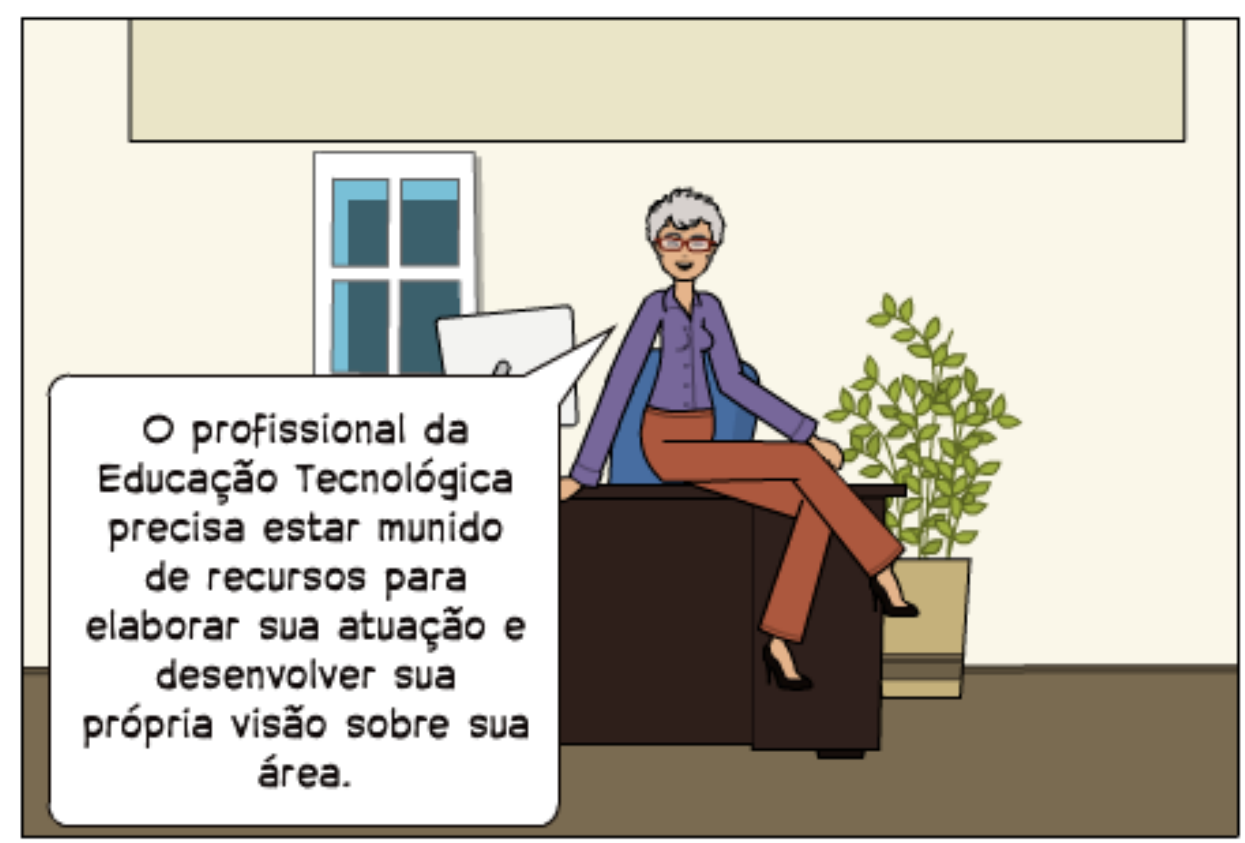




\section{Parte III - Proposta de discussão}

Munidos de um pouco de informação histórica, dos conceitos, das definições e das propostas oficiais e institucionais, podemos dar início ao diálogo proposto por esse fórum de debates, cuja questão norteadora é tão simplesmente:

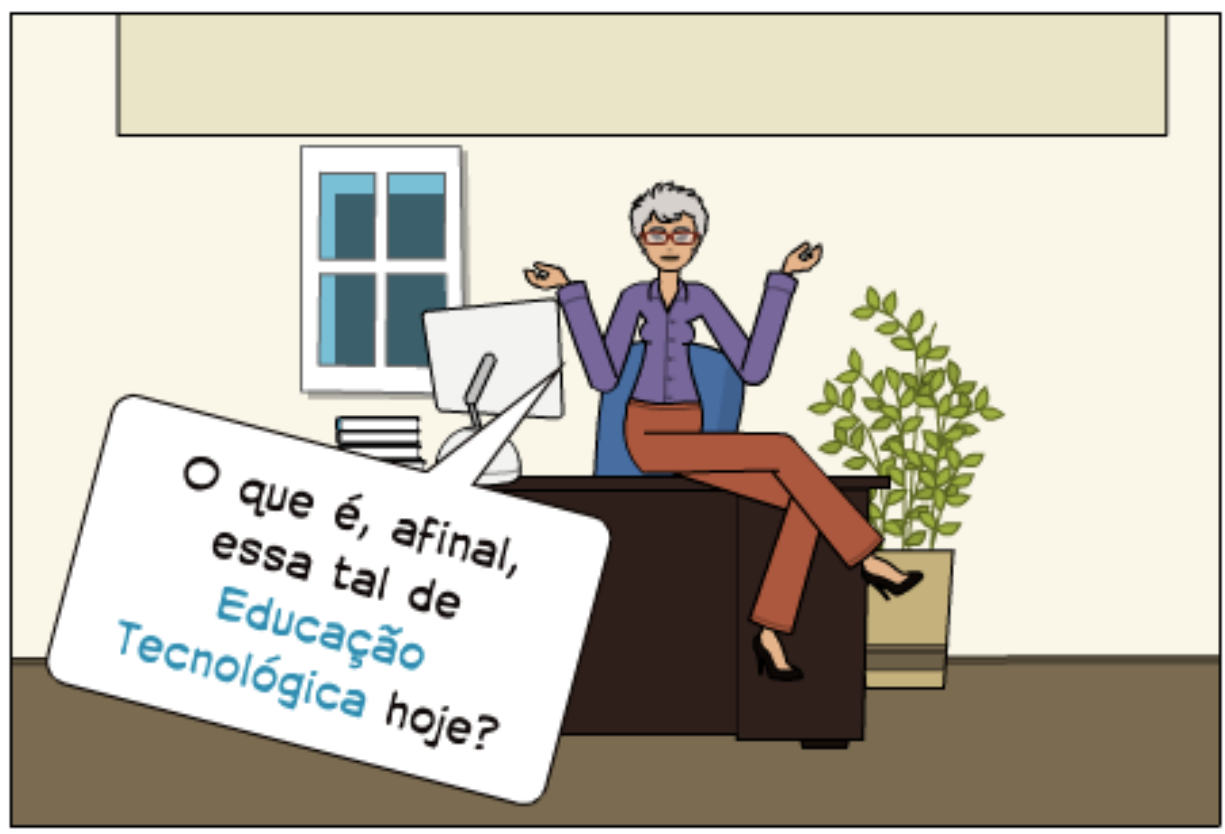

Nos caminhos do diálogo que travaremos em busca desta resposta, talvez possamos definir nossas posições na dupla dimensão que se coloca, no dizer de Frigotto (2001):

[a crise do trabalho assalariado no contexto do neoliberalismo ou do mercado como deus absoluto das relações sociais] assume uma dupla dimensão - de perigo, risco, violência, mas também de possibilidades alternativas. [...] é nessa travessia que podemos situar a ciência, a tecnologia, a educação em geral ou a educação profissional como instrumentos de ampliação e legitimação da exclusão ou como mediações importantes sociais, culturais, econômicas e estéticas de emancipação humana. 


\section{REFERÊNCIAS}

BRASIL. Lei n. 9.394/96, de 20 de dezembro de 1996. Estabelece as Diretrizes e Bases da Educação Nacional. Brasília, 1996.

CEETEPS - Centro Estadual de Educação Tecnológica Paula Souza. Projeto Pedagógico Institucional - PPI. São Paulo: 2010.

MEC. CNE/CP/2002. Diretrizes Curriculares Cursos Superiores de Tecnologia. Brasília: 2002.

MEC. PARECER CNE/CP: 29/2002. Diretrizes Curriculares Nacionais Gerais para a Educação Profissional de Nível Tecnológico. Brasília: 2002.

ROMANELLI, Otaíza de O. História da Educação no Brasil, Petrópolis: Editora Vozes, 1987.

SAVIANI, Demerval. Trabalho e Educação: fundamentos ontológicos e históricos. Revista Brasileira de Educação v. 12 n. 34 jan./abr. 2007

SAVIANI, Demerval. O choque teórico da politecnia. Trabalho, Educação e Saúde, 1(1):131-152, 2003 


\section{LEITURAS RECOMENDADAS}

BATISTA, Sueli Soares dos Santos. Educação Profissional e tecnológica: politecnia e emancipação. In: Educação Tecnológica: Reflexões, teorias e práticas. Jundiaí: Palco Editorial, 2012.

DOS SANTOS, Jailson Alves. A Trajetória da Educação Profissional, in: 500 anos de Educação no Brasil. Belo Horizonte: Autêntica, 2000. $2^{a}$ edição.

GOMES, Carlos Minayo; FRIGOTTO, Gaudêncio; ARRUDA, Marcos; ARROYO, Miguel; NOSELLA, Paolo. Trabalho e Conhecimento: Dilemas na Educação do Trabalhador. São Paulo: Cortez, 2002

SANTOS, Boaventura de Sousa. A universidade no Século XXI: para uma reforma democrática e emancipatória da Universidade. São Paulo: Cortez, 2005. 